\title{
AVALIAÇÕES DA RELAÇÃO K:N E HÍBRIDOS DE MELÃO EM CULTIVO HIDROPÔNICO
}

\author{
RENATA NITOLO CORRÊA DOS SANTOS
}

Engenheiro Agrônomo

Orientador: Prof. Dr. KEIGO MINAMI

Dissertação apresentada à Escola Superior de Agricultura "Luiz de Queiroz", Universidade de São Paulo, para obtenção do título de Mestre em Agronomia, Área de Concentração: Fitotecnia

PIRACICABA

Estado de São Paulo - Brasil

Julho -2002 


\title{
Dados Internacionais de Catalogação na Publicação (CIP) DIVISÃo DE BIBLIOTECA E DOCUMENTAÇÃO - Campus "Luiz de Queiroz"/USP
}

\author{
Lima, Israel Luiz de \\ Variaçào de propriedades indicativas da tensảo de crescimento em funçảo da \\ posiçảo na árvore e da intensidade de desbaste / Israel Luiz de Lima. . Piracicaba, \\ 2000. \\ 90 p. : il.
}

Disserzaçảo (mestrado) - Escola Superior de Agricultura Luiz de Queiroz, 2000. Bibliografia.

1. Crescimento vegetal 2. Desbaste 3. Madeira serrada de eucalipto 4. Manejo florestal 5. Propriedade fisica 6. Qualidade 7. Rachadura 8. Tecnologia de madeira I. Titulo

CDD 674.142

"Permitida a cópia total ou parcial deste documento, desde que citada a fonte - $\mathrm{O}$ autor" 
À Deus por ter me dado força nos momentos difíceis,

E por ter me presenteado com uma família especial,

Agradeço

Aos meus pais Domingos e Maria Helena pela educacão, compreensão e dedicação, À minha irmã Flávia pelo apoio e paciência, À minha filha Carolina por todo amor e carinho, 


\section{AGRADECIMENTOS}

Ao Prof. Keigo Minami pela orientação e confiança depositada;

Ao Departamento de Produção Vegetal da Escola Superior de Agricultura "Luiz de Queiroz" - USP, pela infra-estrutura concedida para a realização desta pesquisa;

Ao Prof. Durval Dourado Neto, coordenador da CPG em Fitotecnia ESALQ/USP, pelo apoio, quando mais necessitei;

Ao $\mathrm{CNPq}$ pela concessão da bolsa de estudos, proporcionada pela Instituição;

Ao Diretor de Pesquisa Paulo Tarcísio Della Vecchia da Sakata Seed Sudamérica, pelas idéias e sugestões;

Ao Pesquisador Pedro Roberto Furlani do IAC, pela amizade, apoio e aprendizado;

Às Empresas Sakata Seed Sudamérica Ltda., Rogers Seeds, Hydrogood Hidroponia Moderna, Nutriplan Ind. e Comércio Ltda., Belgo Mineira Bekaert, Floral Atlânta Ind. e Comércio Ltda. e Mondialle Design Ind. de Banheiras Ltda.;

Ao Prof. Quirino Augusto de Camargo Carmelo, do Dep ${ }^{\text {to }}$ de Solos e Nutrição de Plantas - ESALQ/USP, pelo auxílio prestado e soluções de problemas;

Ao aluno de Graduação Ricardo Danilo Komesu pela grande amizade e auxílio na realização desta pesquisa;

Ao Prof. Luís Carlos Marchini, do Dep ${ }^{\underline{t 0}}$ de Entomologia, Fitopatologia e Zoologia Agrícola - ESALQ/USP, pelo fornecimento da colmeia de abelhas para polinização das flores; 
Ao Prof. Hiroshi Kimati, do Dep ${ }^{\text {to }}$ de Entomologia, Fitopatologia e Zoologia Agrícola - ESALQ/USP, pelo diagnóstico de doença ocorrido no experimento;

Ao Prof. Jorge Horii do Dep ${ }^{\text {to }}$ de Agroindústria, Alimentos e Nutrição ESALQ/USP, pela infra-estrutura na realização das análises fisicas e química;

Ao Prof. Ângelo Pedro Jacomino do Dep ${ }^{10}$ de Produção Vegetal ESALQ/USP, por haver cedido equipamento para determinação de firmeza da polpa;

À Prof. Sônia Maria de Stefano Piedade, do Dep ${ }^{\text {to }}$ de Ciências Exatas ESALQ/USP, pela amizade, dedicação e ensinamentos na área de estatística;

Aos funcionários da Biblioteca Central - ESALQ/USP, em especial à bibliotecária Eliana Maria Garcia;

Aos Funcionários do Departamento de Produção Vegetal - ESALQ/USP, pela execução da reforma da estrutura, do auxílio prestado e principalmente pela amizade;

Aos companheiros do curso de Pós-Graduação pelos anos de convivência. 


\section{SUMÁRIO}

Página

LISTA DE FIGURAS................................................................ ix

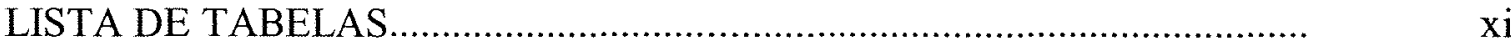

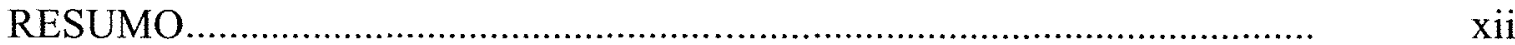

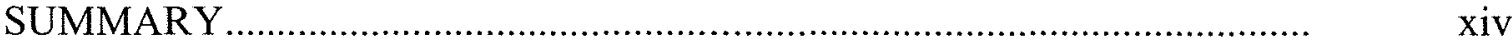

1 INTRODUÇÃ

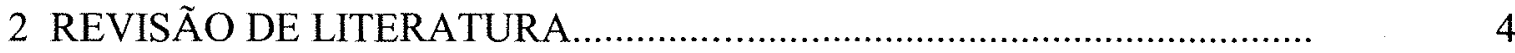

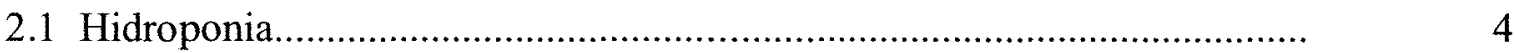

2.1.1 Conceito e histórico.................................................................

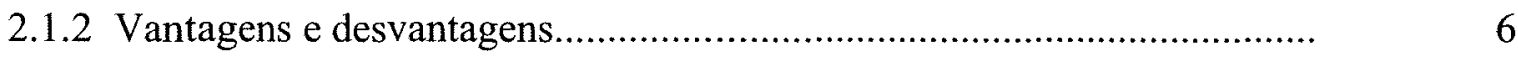

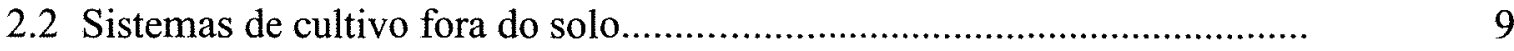

2.3 Técnica do fluxo laminar de nutrientes (NFT)................................ 11

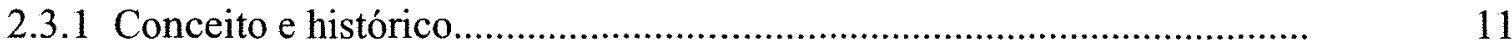

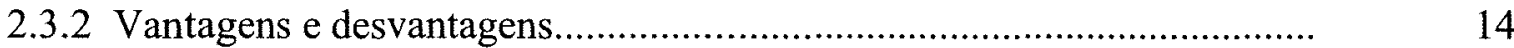

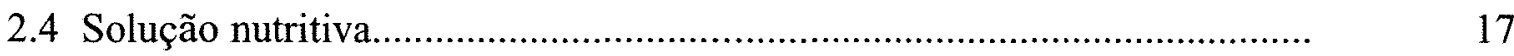

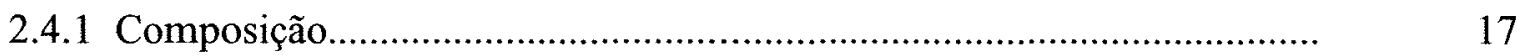

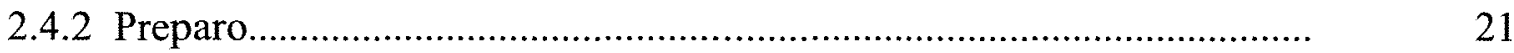




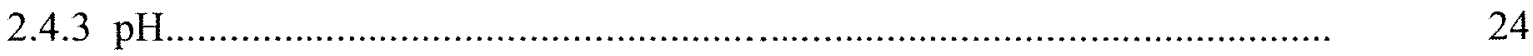

2.4.4 Condutividade elétrica (EC), reposição e troca........................................ 26

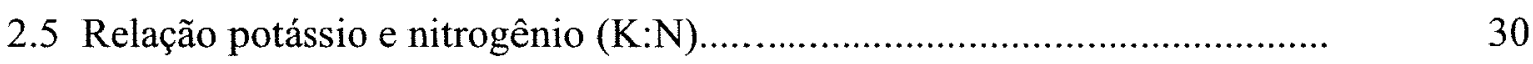

2.5.1 Absorção de nutrientes...................................................................... $\quad 30$

2.5.2 Absorção de nutrientes em hidroponia......................................................... 33

3 MATERIAL E MÉTODOS...................................................................

3.1 Condições experimentais..................................................................... 35

3.2 Delineamento e fatores analisados.............................................................

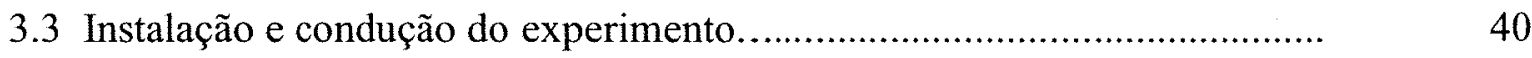

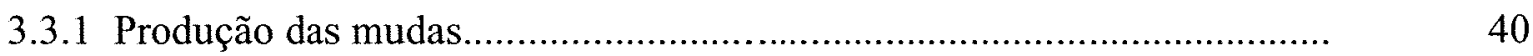

3.3.2 Transplante intermediário e condução......................................................... 41

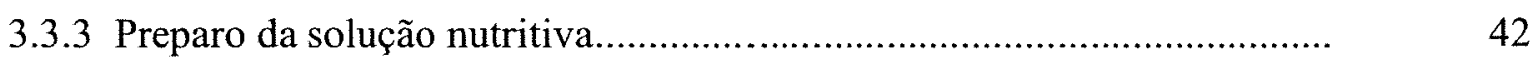

3.3.4 Transplante definitivo e condução do experimento..................................... 44

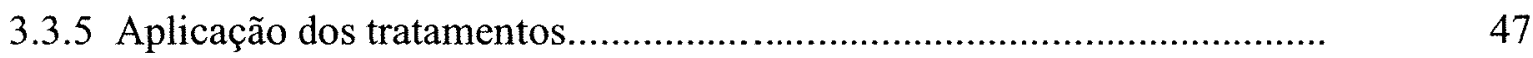

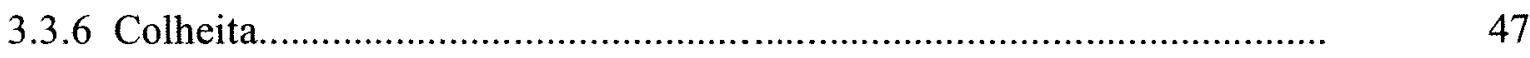

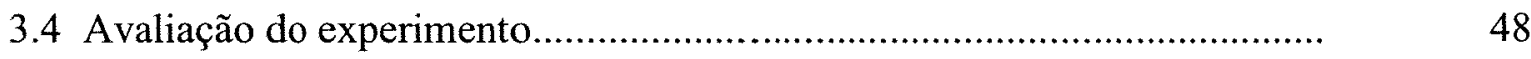

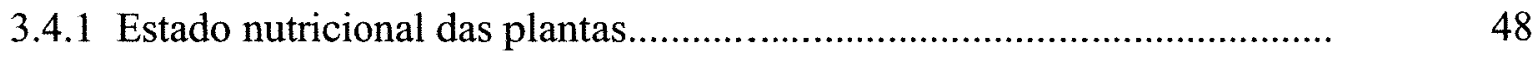

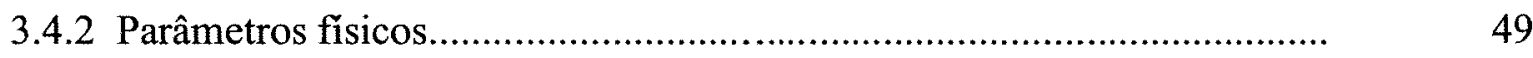

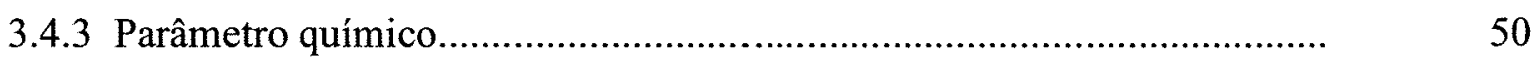

4 RESULTADOS E DISCUSSÃO ……………......................................

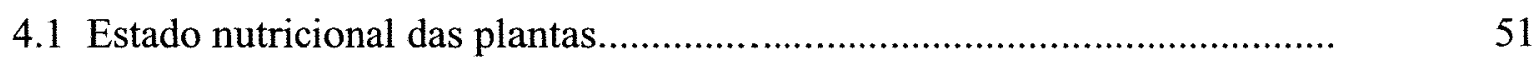

4.2 Parâmetros fisicos e químico.....................................................................

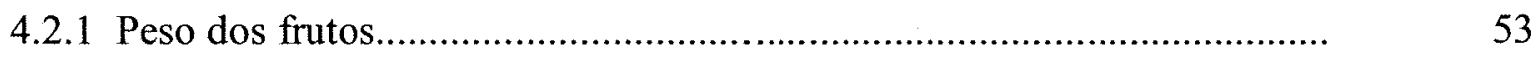

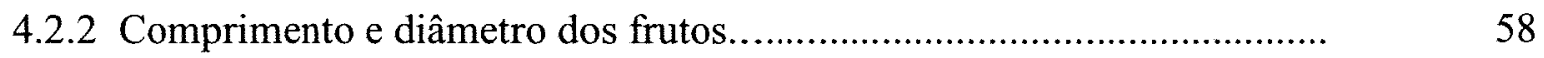


4.2.3 Comprimento e diâmetro da cavidade............................................. 61

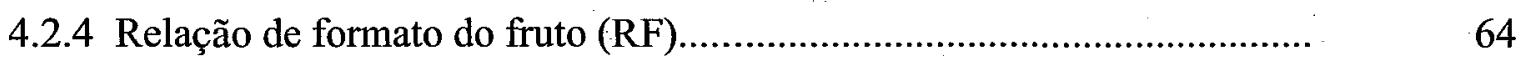

4.2.5 Espessura distal e espessura da polpa............................................ 66

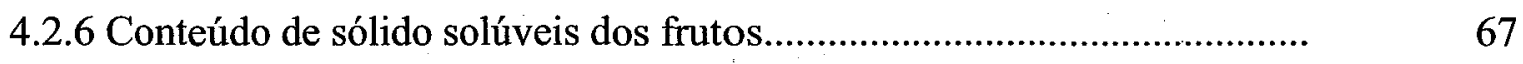

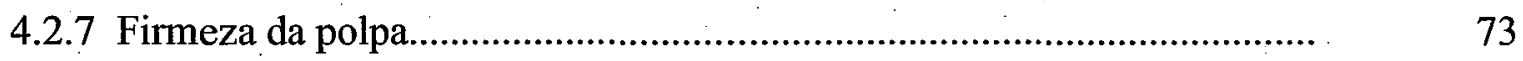

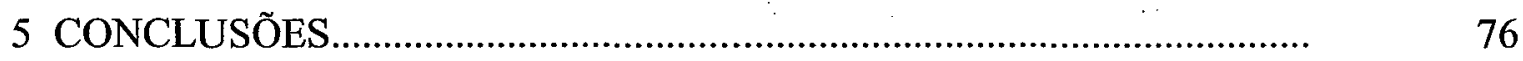

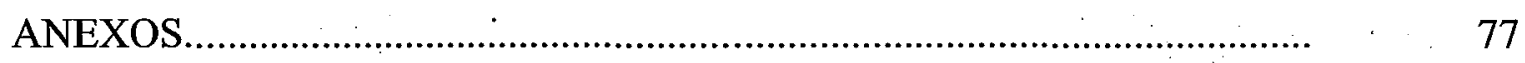

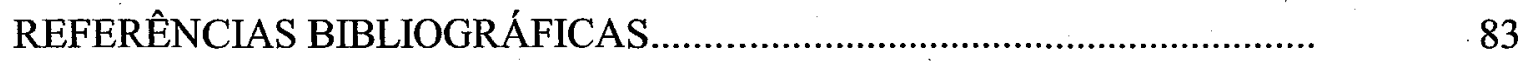




\section{LISTA DE FIGURAS}

Página

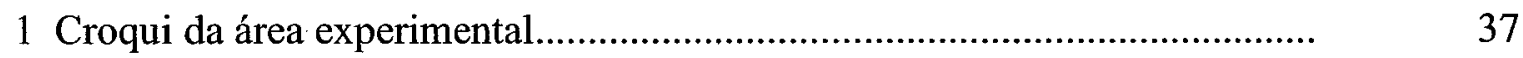

2 Peso médio de frutos, nas soluções 1 e 2 para os híbridos Orange Flesh e Galileo, ESALQ - USP, Piracicaba - SP, 2001 .......................................

3 Comprimento médio de frutos, nas soluções 1 e 2 para os híbridos Orange Flesh e Galileo, ESALQ - USP, Piracicaba - SP, 2001 ..............................

4 Diâmetro médio de frutos, nas soluções 1 e 2 para os híbridos Orange Flesh e Galileo, ESALQ - USP, Piracicaba - SP, 2001

5 Comprimento médio da cavidade, nas soluções 1 e 2 para os híbridos Orange Flesh e Galileo, ESALQ - USP, Piracicaba - SP, 2001

6 Diâmetro médio da cavidade, nas soluções 1 e 2 para os híbridos Orange Flesh e Galileo, ESALQ - USP, Piracicaba - SP, 2001

7 Valores médios da relação de formato dos frutos, nas soluções 1 e 2, para os híbridos Orange Flesh e Galileo, ESALQ - USP, Piracicaba - SP, 2001.

8 Espessura média distal, nas soluções 1 e 2, para os híbridos Orange Flesh e Galileo, ESALQ - USP, Piracicaba - SP, 2001 
9 Espessura média da polpa, nas soluções 1 e 2, para os híbridos Orange Flesh e Galileo, ESALQ - USP, Piracicaba - SP, 2001.......................... 68

10 Conteúdo médio de sólido solúveis, nas soluções 1 e 2, para os híbridos Orange Flesh e Galileo, ESALQ - USP, Piracicaba - SP, 2001 ...................

11. Firmeza média da polpa, nas soluções 1 e 2, para os híbridos Orange Flesh e Galileo, ESALQ - USP, Piracicaba - SP, 2001 .......................... 


\section{LISTA DE TABELAS}

Página

1 Análise de variância para as características: peso médio do fruto $(\mathrm{PF})$, comprimento médio do fruto $(\mathrm{CF})$, diâmetro médio do fruto $(\mathrm{DF})$, comprimento médio da cavidade (CC) e diâmetro médio da cavidade (DC). ESALQ - USP, Piracicaba -SP, 2001

2 Análise de variância para as características: relação de formato (RF), espessura média distal (ED), espessura média da polpa (EP), conteúdo médio de sólido solúveis (SS) e firmeza média da polpa (FIR). ESALQ USP, Piracicaba -SP, 2001

3 Médias observadas nos híbridos Orange Flesh e Galileo para os parâmetros: peso médio do fruto $(\mathrm{PF})$, comprimento médio do fruto $(\mathrm{CF})$, diâmetro médio do fruto (DF), comprimento médio da cavidade (CC) e diâmetro médio da cavidade (DC). ESALQ - USP, Piracicaba -SP, 2001

4 Médias observadas nos híbridos Orange Flesh e Galileo para os parâmetros: relação de formato (RF), espessura média distal (ED), espessura média da polpa (EP), conteúdo médio de sólido solúveis (SS) e firmeza média da polpa (FIR). ESALQ - USP, Piracicaba -SP, 2001 


\title{
AVALIAÇÕES DA RELAÇÃO K:N E HÍBRIDOS DE MELÃO EM CULTIVO HIDROPÔNICO
}

\author{
Autora: RENATA NITOLO CORRÊA DOS SANTOS \\ Orientador: Prof. Dr. KEIGO MINAMI
}

\section{RESUMO}

O experimento foi conduzido no período de janeiro a abril de 2001, na área experimental do Departamento de Produção Vegetal, ESALQ-USP. Plantas de melão (Cucumis melo L.), foram cultivadas sob ambiente protegido em Nutrient Film Technique (NFT). Duas soluções nutritivas foram estudadas, onde a solução $1 \mathrm{com}$ relação K:N 1,3:1 foi utilizada do início ao fim do ciclo e a solução 2 com relação $K: N$ 1,3:1 foi utilizada até o início da frutificação e 2,6:1 até o fim do ciclo. Utilizou-se dois híbridos de melão nobre, denominados Orange Flesh e Galileo. As plantas foram tutoradas na vertical e conduzidas em haste única com a fixação de dois frutos por planta. Os parâmetros avaliados foram peso, comprimento, diâmetro, comprimento e diâmetro da cavidade, relação de formato, espessura distal e da polpa, conteúdo de sólido solúveis e firmeza da polpa, além do estado nutricional das plantas. O delineamento experimental adotado foi de blocos ao acaso, constando de 2 tratamentos e 10 repetições (blocos). Os resultados obtidos, nas condições em que se desenvolveu a presente pesquisa, revelaram que a solução 2 proporcionou aumento de peso, 
comprimento, diâmetro, diâmetro da cavidade, espessura da polpa e conteúdo de sólido solúveis para o híbrido Orange Flesh, sendo considerada mais adequada ao híbrido. Em relação ao híbrido Galileo a solução 1 proporcionou melhor resultado, obtendo maior espessura da polpa. 


\title{
EVALUATIONS OF K:N RATIO AND MUSKMELON HYBRIDS IN HIDROPONIC CULTURE
}

\author{
Author: RENATA NITOLO CORREAA DOS SANTOS
}

Adviser: Prof. Dr. KEIGO MINAMI

\section{SUMMARY}

The experiment was conducted in the period of January to April of 2001, in the experimental area of the Vegetable Production Department, ESALQ - São Paulo University. Muskmelon plants (Cucumis melo L.) were cultivated under greenhouse in Nutrient Film Technique (NFT). Two nutrient solutions were studied, where the solution $1 \mathrm{~K}: \mathrm{N}$ ratio 1,3:1 was used of the beginning to the end of the cycle and the solution 2 $\mathrm{K}: \mathrm{N}$ ratio $1,3: 1$ was used up to the benning of the flowering and 2,6:1 to the end of the cycle. It was used muskmelon hybrids Orange Flesh and Galileo. The plants were supported in to vertical and conducted in only stem with the fixation of two fruits per plant. The appraised parameters were fruit weight, length, diameter, length and diameter of the cavity, index of shape, thickness distal and of the flesh, soluble solid content and firmness of the flesh, besides nutritional status of the plants. The experimental design adopted was the randomized blocks, consisting of 2 treatments and 10 replications (blocks), with two hybrids. The results, revealed that the solution 2 provided increasing in weight, length, diameter, diametre of the cavity, thickness of the flesh and content of soluble solids for hybrid Orange Flesh, being considered more adapted to the hybrid. In 
relation to hybrid Galileo the solution 1 provided better result, obtaining a higher increase in thickness of the flesh. 


\section{INTRODUÇÃO}

O melão era considerado até alguns anos atrás um artigo de "luxo", já que o consumo era suprido, em sua maior parte, com melão importado da Europa (Melo et al., 1998). No entanto, o processo inverteu-se e o Brasil passou de importador a exportador dessa hortaliça graças, principalmente, às condições climáticas favoráveis existentes na região Nordeste do país.

A produção brasileira de melão, em 1999, foi da ordem de 173.866 milhões de frutos, sendo que somente a região Nordeste participou com 164.411 milhões de frutos, enquanto que as regiões Sul, Sudeste e Centro Oeste juntas participaram com apenas 9.021 milhões de frutos (Agrianual, 2002).

O melão é um fruto de boa aceitação para a exportação, porém, na produção de 1997 apenas 25\% foi exportado (Marino et al., 2001). Do melão produzido no Estado do Rio Grande do Norte, mais de 60\%, destina-se ao mercado interno (Souza, 1994). Na verdade, a maior parte da produção é comercializada internamente, e o grande centro consumidor desta hortaliça é a região Sudeste, principalmente o Estado de São Paulo.

Na região Sudeste, a cultura tem sido pouco explorada. A principal razão é a ocorrência de chuvas no período quente do ano, época considerada mais propícia para o cultivo, levando à incidência de doenças e depreciando a qualidade do produto (Carneiro Filho, 2001).

Como se observa na literatura, o ambiente protegido possibilita o cultivo do melão em diferentes épocas do ano (Brandão Filho \& Vasconcellos, 1998 e Pereira \& Marchi, 2000). Isto é possível devido ao fato de se ter um relativo controle sobre os 
fatores climáticos prejudiciais à cultura, tais como, o vento, geadas, granizo e o excesso de chuvas.

Conforme ressalta Filgueira (2000), o clima quente e seco favorece o meloeiro, a produtividade e também a qualidade dos frutos, contribuindo para elevar o teor de açúcares, tornando o sabor e o aroma mais ricos e melhorando a consistência e a durabilidade. Em regiões úmidas, com pouca insolação e baixa temperatura, os frutos não amadurecem adequadamente e perdem muito em qualidade (Zapata et al., 1989). Devido a estes fatores, o melão na região Sudeste deve ser cultivado em ambiente protegido.

Uma opção para o Estado de São Paulo seria o plantio em ambiente protegido de melões nobres, pois, estes não possuem concorrentes no mercado nacional. Já que em função da necessidade de resistência ao transporte a longas distâncias e ao armazenamento precário, o cultivo do melão na região Nordeste ficou restrito ao tipo amarelo Valenciano, de origem espanhola. Os melões nobres ainda apresentam ótima qualidade quanto ao sabor, aroma e textura.

A plasticultura e hidroponia são duas tecnologias de destaque na diversificação de produção de hortaliças (Junqueira, 1999). Talvez, na região Sudeste, em áreas próximas de grandes centros populacionais, exigentes em produtos diferenciados e de boa qualidade, o cultivo de melão nobre em sistema hidropônico seja uma alternativa viável. Isso porque a tendência é do mercado consumidor buscar a produção de alimentos com melhores características sensoriais, produtos diferenciados e com menores cargas de agroquímicos.

O cultivo de melão nobre em hidroponia aponta perspectivas para a exploração comercial, tais como: a exploração de pequenas áreas próximas aos grandes centros urbanos, é cultura de ciclo curto, sem concorrente no mercado, é um produto diferenciado, apresentando maior valor agregado e boa cotação de preço, além de atender aos consumidores de maior poder aquisitivo.

Para a alface já existem informações científicas para o seu cultivo hidropônico no Brasil, uma vez que foi a cultura pioneira; porém com relação ao melão, existe uma grande carência de informações. 
Assim sendo, o presente trabalho teve como objetivo o estudo do comportamento de dois híbridos de melões nobres, submetidos a duas diferentes soluções nutritivas, aplicadas através da técnica do NFT, para a avaliação das características qualitativas dos frutos. 


\section{REVISÃO DE LITERATURA}

\subsection{Hidroponia}

\subsubsection{Conceito e histórico}

Segundo Carmello \& Furlani (1994), o termo hidroponia, foi proposto por volta de 1930 pelo norte-americano William F. Gericke, para designar o cultivo de plantas em meio líquido. Os autores comentam que o termo hidroponia deriva de duas palavras de origem grega: hydro, que significa água e ponos, que significa trabalho. De acordo com Resh (1992), é literalmente trabalho em água.

Conforme Resh (1992), o cultivo de plantas sem solo foi desenvolvido a partir de descobertas realizadas com a finalidade de determinar-se as substâncias responsáveis pelo desenvolvimento e constituição das plantas. Ainda de acordo com o autor, o primeiro estudo científico sobre a composição das plantas data do ano de 1600 , quando o belga Jan van Helmont, em sua clássica experiência, concluiu que as plantas obtém da água substâncias para seu crescimento.

Segundo Martinez \& Silva Filho (1997), em 1699, o inglês John Woodward cultivou plantas em água com diversos tipos de solo, observou melhor desenvolvimento nos tratamentos com maior quantidade de solo e concluiu que a planta não era composta apenas por água, mas também de substâncias do solo que eram dissolvidas na água.

Os autores relatam que em 1804, De Saussure estabeleceu que as plantas são compostas por elementos químicos obtidos da água, solo e ar. Segundo Resh (1992), este princípio foi comprovado em 1851, pelo químico francês Boussingault em 
seus ensaios com plantas desenvolvidas em areia, quartzo e carvão vegetal, concluindo que a água fornece $\mathrm{H}$, o ar $\mathrm{C}_{\text {e } \mathrm{O}_{2}}$ e o solo fornece os minerais indispensáveis à vida da planta.

Castellane \& Araujo (1995) afirmam que foi durante o periodo de 1850 a 1855 que quase todos os elementos minerais essenciais ao desenvolvimento das plantas foram descobertos, utilizando-se alguma forma de cultivo sem solo.

Carmello \& Furlani (1994) relatam que os alemãs Julius von Sachs (1860) e W. Knop (1861) cultivaram pela primeira vez plantas em solução nutritiva, dispensando qualquer meio sólido para o crescimento das plantas.

Segundo Martinez e Silva Filho (1997), a partir de então, essa técnica passou a ser usada em pesquisas sobre nutrição mineral de plantas utilizando-se soluções aquosas contendo $\mathrm{N}, \mathrm{P}, \mathrm{S}, \mathrm{K}, \mathrm{Ca}$ e $\mathrm{Mg}$; atualmente denominados macronutrientes. Com posteriores avanços na Química e técnicas laboratoriais, foram descobertos os micronutrientes ( $\mathrm{Fe}, \mathrm{Cl}, \mathrm{Mn}, \mathrm{B}, \mathrm{Zn}, \mathrm{Cu}$ e $\mathrm{Mo}$ ). Consequentemente, muitas formulações foram desenvolvidas, algumas delas como a de Hoagland e Arnon, 1950, usadas até hoje.

Resh (1992) comenta que, em 1925, o interesse pelo cultivo comercial foi despertado, porém na década de 30, foi aos poucos abandonado, em razão do sensacionalismo com que as técnicas de cultivo hidropônico foram apresentadas e da venda de equipamentos inadequados ao cultivo. No início dos anos 30, W. F. Gericke realizou ensaios de nutrição em escala comercial, denominando hidroponia. Mas, foi durante a $2^{\mathrm{a}}$ Guerra Mundial que o cultivo hidropônico de Gericke recebeu grande impulso, demonstrando sua utilidade na produção de hortaliças para as tropas americanas estacionadas nas ilhas incultiváveis do Pacífico (ilhas rochosas).

Segundo Huterwal (1960), os soldados americanos sentiam repulsa frente a idéia de consumir hortaliças cultivadas em terrenos fertilizados com material humano, o qual constitui uma prática milenar na agricultura do Japão e da China.

De acordo com Martinez \& Silva Filho (1997), merecem destaque os trabalhos de Allen Cooper, que na década de 70 introduziu na Inglaterra a técnica do 
NFT (Nutrient Film Technique), fazendo com que o cultivo hidropônico comercial se tornasse uma realidade.

Resh (1992) afirma que o crescimento do cultivo protegido tem sido um estímulo adicional ao desenvolvimento da hidroponia. O uso da plasticultura reduziu muito os custos. O desenvolvimento de bombas, perfis, tubos, registros e outros equipamentos possibilitou automatizar o cultivo hidropônico, contribuindo também para a redução dos custos operacionais.

Segundo o mesmo autor, atualmente os sistemas hidropônicos são muito utilizados em países desenvolvidos, principalmente em razão dos problemas de inverno rigoroso (Holanda, USA e França); das limitações de área (Japão); da escassez hídrica (Israel). Tem sido utilizado também para resolver problemas específicos, como por exemplo, o clima de monções na Malásia; regiões áridas do México, USA e Oriente Médio; em áreas costeiras ou onde o solo é pouco fértil e até mesmo onde a topografia é inadequada.

Ainda de acordo com o autor é interessante lembrar que muitos anos antes de 1600, plantas já eram cultivadas sem solo, exemplo disto, são os jardins suspensos da Babilônia, os jardins flutuantes dos Astecas no México, e os da China Imperial.

\subsubsection{Vantagens e desvantagens}

Teixeira (1996) afirma que são inúmeras as vantagens em se cultivar por hidroponia, entre as quais destacam-se:

1. produção de melhor qualidade - o tamanho e a aparência de qualquer produto hidropônico são sempre iguais durante o ano todo; hortaliças folhosas, são viçosas e com todas as folhas aproveitáveis.

2. emprego de mão-de-obra é menor - diversas práticas agrícolas, como aração, gradagem, capinas não são necessárias e outras , como irrigação e adubação são automatizadas na maioria das vezes.

3. mínimo uso de fungicidas e inseticidas - como não se emprega o solo e o plantio é em meio limpo, a ocorrência de pragas e doenças é muito menor. 
4. colheita precoce - é oferecido às plantas boas condições para o desenvolvimento, suas raízes não empregam demasiada energia para crescer.

5. menor consumo de água e adubo - o aproveitamento dos insumos em questão é mais racional, proporcionando economia se comparado ao sistema convencional de cultivo.

6. melhor possibilidade de colocação do produto no mercado - como o produto é de melhor qualidade e aparência, tamanho maior, sendo um produto diferenciado, devese obter, pelo menos teoricamente, melhor preço e a comercialização ser mais fácil.

7. Utilização racional de áreas - é uma opção para o emprego de pequenas áreas e também uma opção para áreas incultiváveis pelo sistema tradicional.

A autora apresenta ainda as principais desvantagens do cultivo hidropônico:

1. emprego de inseticidas e fungicidas - problemas com pragas e doenças ocorrem, embora em menor grau em comparação ao sistema convencional. Entretanto, a decisão quanto ao uso de inseticidas e fungicidas é sempre difícil, pois acarreta na perda de um dos atrativos de comercialização. Deve-se buscar alternativas menos agressivas à saúde e ao meio ambiente.

2. dependência de eletricidade nos sistemas automáticos - de acordo com o tipo da instalação, a falta de energia por cerca de duas horas fará com que ocorra morte das plantas pela falta de água. Pode-se acrescentar o custo da energia.

3. necessidade de mão-de-obra especializada - é imprescindível certo conhecimento de fisiologia de planta e, muitas vezes, de química.

4. atividades rotineiras - o que pode levar a negligência.

5. alto custo da instalação comercial.

Hanger ${ }^{1}$ citado por Castellane \& Araujo (1995), apresenta outras

\footnotetext{
${ }^{1}$ HANGER, B.C. The nutrient solution and its preparation. In: Hydroponics for schools and the home grower. Melbourne: Victorian Schools' Nursey, 1986. p.21-33.
} 
vantagens do cultivo sem solo: não é necessário a rotação de cultura, e o meio de crescimento pode ser reutilizado continuamente, durante até cinco ou mais anos (dependendo do meio); além disso as plantas são uniformes quanto ao desenvolvimento.

Stoughton (1969) afirma que o cultivo sem solo apresenta como vantagens a menor probabilidade de ocorrência de doenças de raízes, pois, as condições da solução nutritiva e substrato são menos favoráveis ao crescimento de fungos e bactérias patogênicas do que em solo. A multiplicação de nematóides em solução nutritiva, é dificultada. A principal vantagem é a esterilização do meio de crescimento, que é mais simples e menos custosa do que a esterilização do solo. O meio pode ser lavado, por repetidos fluxos de água. No entanto, quando todas as plantas de uma bancada são expostas à mesma solução nutritiva, uma raiz doente, que permaneça no sistema, pode contaminar todas as plantas, sendo essa a principal desvantagem.

Resh (1992) estabelece um comparativo de produção entre cultivo com solo e sem solo (Quadro 1) e Castellane \& Araujo (1995), adaptado de Jensen \& Collins (1985), apresentam produções de algumas hortaliças cultivadas em estufas com sistema hidropônico e em campo (Quadro 2).

\begin{tabular}{|l|c|c|}
\hline \multicolumn{1}{|c|}{ Cultura } & Com solo & Sem solo \\
\hline Soja & 0,27 & 0,70 \\
\hline Feijão & 5,00 & 21,00 \\
\hline Ervilha & 1,00 & 9,00 \\
\hline Trigo & 0,27 & 1,80 \\
\hline Arroz & 0,45 & 2,20 \\
\hline Aveia & 0,45 & 1,10 \\
\hline Beterraba & 4,00 & 12,00 \\
\hline Batata & 8,00 & 70,00 \\
\hline Repolho & 6,00 & 8,20 \\
\hline Alface & 4,00 & 9,50 \\
\hline Tomate & 7,50 & 150,00 \\
\hline Pepino & 3,20 & 12,70 \\
\hline
\end{tabular}

Fonte: Resh (1992)

Quadro 1- Comparativo de produção $(\mathfrak{t})$, em $4050 \mathrm{~m}^{2}$, entre cultivo com e sem solo. 
Castellane \& Araujo (1995) apresentam outras desvantagens do cultivo sem solo: o balanço inadequado da solução nutritiva e a sua posterior utilização podem causar sérios problemas às plantas; o meio de cultivo deve prover suportes às raízes e estruturas aéreas das plantas, reter boa umidade, e ainda, apresentar boa drenagem, ser totalmente inerte e facilmente disponível; por fim, se a água se contaminar, todo o sistema é afetado.

Rresh (1992) afirma que a maiores desvantagens do cultivo hidropônico são: o elevado capital inicial; algumas doenças, como Fusarium e Verticillium, as quais podem estender-se rapidamente através do sistema e o surgimento de problemas nutricionais complexos. Estas desvantagens podem ser solucionadas, pois, o capital e a complexidade do trabalho deste sistema pode ser reduzidos utilizando-se novos métodos hidropônicos mais simples, tais como Nutrient Film Technique (NFT), assim como o uso de variedades resistentes aos patógenos já mencionados acima.

\begin{tabular}{|l|c|c|c|c|}
\hline \multirow{2}{*}{ Culturas } & \multicolumn{3}{|c|}{ Estufa com hidroponia } & Condições de campo \\
\cline { 2 - 5 } & $\mathrm{t} / \mathrm{ha}$ & $\mathrm{n}^{\mathrm{o}}$ de cultivo & $\mathrm{t} / \mathrm{ha} /$ ano & t/ha/ano \\
\hline Brócolis & 32,5 & 3 & 97,5 & 10,5 \\
\hline Feijão vagem & 11,5 & 4 & 46,0 & 6,0 \\
\hline Repolho & 57,5 & 3 & 172,5 & 30,0 \\
\hline Couve-chinesa & 50,0 & 4 & 200,0 & - \\
\hline Pepino & 250,0 & 3 & 750,0 & 30,0 \\
\hline Berinjela & 28,0 & 2 & 56,0 & 20,0 \\
\hline Alface & 31,3 & 10 & 313,0 & 52,0 \\
\hline Pimentão & 32,0 & 3 & 96,0 & 16,0 \\
\hline Tomate & 187,5 & 2 & 375,0 & 100,0 \\
\hline
\end{tabular}

Fonte: Castellane \& Araujo (1995)

Quadro 2- Produções de algumas hortaliças cultivadas em estufas com sistema hidropônico e em campo.

\subsection{Sistemas de Cultivo fora do solo}

Segundo Castellane \& Araujo (1995), em função da classificação adotada em 1976 no INTERNATIONAL CONGRESS OF SOILLESS CULTURE, a hidroponia 
é classificada como cultura em água, onde as raízes das plantas são imersas na solução nutritiva: Deep Film Technique (DFT), Nutrient Film Technique (NFT) e Aeroponia.

Ainda segundo os autores, no cultivo sem solo, podem ser utilizados diferentes substratos sólidos, inorgânicos ou orgânicos, ou ainda, misturas entre eles. No caso da hidroponia, as raízes ficam em meio líquido (solução nutritiva), permanentemente ou temporariamente. Já na aeroponia, elas ficam suspensas, sendo a solução nutritiva nebulizada sobre elas.

Papadopoulos (1994) concorda com Resh (1992), Jones Junior (1983) e Stoughton (1969), somente o cultivo em água (solução nutritiva) seria considerado a verdadeira hidroponia e os outros métodos de cultivo sem a utilização do solo, porém, com algum meio de cultivo (substrato), seriam denominados de cultivo sem solo.

Segundo Andriolo (1999), os sistemas de cultivo de plantas fora do solo que são atualmente empregados no mundo, se enquadram em duas grandes modalidades: hidroponia e cultivo em substratos.

Para o autor, a hidroponia consiste em cultivar plantas diretamente na solução nutritiva, sem substratos. Já o cultivo em substratos consiste em cultivar plantas em substratos diferentes do solo, inertes ou não. Um substrato é considerado como sendo constituído apenas pela fase sólida do meio radicular. As duas outras fases são a água e o ar $\mathrm{FAO}^{2}$ citado por (Andriolo, 1999).

Castellane \& Araujo (1995) concordam com Resh (1992),mencionando que as modalidades de sistemas hidropônicos existente são o cultivo em tanque (DFT), cultivo em filme nutritivo (NFT) e aeroponia, ou seja, cultivos em solução nutritiva. Andriolo (1999) não menciona a aeroponia como sendo uma modalidade de sistema hidropônico.

Martinez \& Barbosa (1999) afirmam que o limite entre hidroponia e cultivo convencional muitas vezes se confundem. Isso porque atualmente, com o uso da fertirrigação, materiais praticamente inertes passaram a ser empregados como substrato

${ }^{2}$ FAO. Soilless culture for horticultural crop production. Rome,1990. 188p. (FAO, Plant Production and Protection Paper, 101). 
na propagação de plantas como para cultivo hidropônico.

Stoughton (1969) comenta que o uso generalizado do termo "hidropônico" para todos os métodos de cultivo sem solo é errôneo, mas o termo ficou tão generalizado que atualmente é impossível substituí-1o do uso comum. O termo hidropônico, deveria ser restrito apenas ao cultivo onde as raízes são em parte, ou completamente submersas em solução nutritiva.

De acordo com Furlani et el. (1999), os tipos de sistema de cultivo hidropônico mais utilizados são:

- NFT: composto basicamente de um tanque de solução nutritiva, de um sistema de bombeamento, dos canais de cultivo e de um sistema de retorno ao tanque. A solução nutritiva é bombeada aos canais e escoa por gravidade formando uma fina lâmina de solução que irriga as raízes;

- DFT: a solução nutritiva forma uma lâmina profunda (5 a $20 \mathrm{~cm})$, na qual as raízes ficam submersas. Não existe canais, e sim uma mesa plana em que a solução circula por meio de um sistema de entrada e drenagem característica;

- Sistema com substratos: para a sustentação de hortaliças frutíferas, de flores e outras culturas, cujo sistema radicular e cuja parte aérea são mais desenvolvidos, utilizam-se canaletas ou vasos cheios de material inerte, como areia, pedras diversas, vermiculita, entre outros; a solução é percolada através desse material e drenada pela parte inferior dos vasos ou canaletas, retornando ao tanque de solução.

\subsection{Técnica do fluxo laminar de nutrientes (NFT)}

\subsubsection{Conceito e hitórico}

Allen Cooper na década de 70 introduziu na Inglaterra a técnica do NFT (Nutrient Film Technique), fazendo com que o cultivo hidropônico comercial se tornasse uma realidade (Martinez, 1997).

Segundo Resh (1992), no cultivo em água, maior ênfase tem sido dada ao NFT, pois, é o mais utilizado. 
De acordo com Furlani et al. (1999), o NFT é composto basicamente por um tanque de solução nutritiva, de um sistema de bombeamento, dos canais de cultivo e de um sistema de retorno ao tanque de solução. A solução nutritiva é bombeada aos canais e escoa por gravidade formando uma fina lâmina de solução que irriga as raízes.

No NFT, o sistema é fechado, pois, a solução nutritiva flui do reservatório para os canais e deste, retorna novamente ao reservatório (Graves, 1983). A circulação da solução pode ser contínua ou intermitente (Papadopoulos, 1994 e Resh, 1992). Os canais apresentam declive entre 1 a 3\% (Teixeira, 1996; Carmello \& Furlani, 1994 e Resh, 1992).

Martinez \& Silva Filho (1997) comentam que, no NFT, as plantas desenvolvem seu sistema radicular de modo que $2 / 3$ deste deva permanecer parcialmente submerso, retirando os nutrientes necessários ao seu desenvolvimento e o $1 / 3$ restante deve desenvolver-se ao ar livre, absorvendo $\mathrm{O}_{2}$.

Segundo Resh (1992), as raízes crescem rapidamente e se estendem por toda a superfície inferior dos canais, seguindo o fluxo da solução nutritiva. Formando, assim, uma capa contínua e espessa no fundo dos canais, que servirá como suporte para as planta conforme vão se desenvolvendo.

Andriolo (1999) afirma que o filme de solução nutritiva não deverá nunca elevar-se acima da massa radicular. Assegurando que todas as raízes estejam úmidas, porém que sua parte superior esteja em contato com o ar mesmo no final do canal para não ocorrer redução na oxigenação.

Castellane \& Araujo (1995) comentam que nas condições em que ocorre saturação de água no sistema radicular e, consequentemente, redução do oxigênio, ocorrerá desenvolvimento de microorganismos próprios de condições anaeróbicas, podendo resultar em ataque às raízes, causando clorose generalizada da planta com posterior morte.

De acordo com Furlani at al. (1999), no NFT, o comprimento dos canais não deve exceder a $30 \mathrm{~m}$, evitando, assim, o aumento de temperatura, redução na oxigenação e concentração de sais da solução ao longo do canal de cultivo, pois, a EC do ambiente radicular é maior do que a EC da solução nutritiva (Stoughton, 1969). 
Quando possível a solução pode ser introduzida em vários pontos ao longo do canal de cultivo (Resh, 1992).

A solução nutritiva deve fluir nos canais de $0,5-1,0 ; 1,5-2,0$ e $2,0-4,0$ $\mathrm{L} / \mathrm{min} /$ canal, para mudas, plantas de ciclo curto e plantas de ciclo longo, respectivamente. O tempo de irrigação varia muito dependendo da região, época do ano, cultivar, tipo de bancada e desenvolvimento da planta. Em geral, durante o verão permanece mais tempo irrigando em relação ao inverno e durante a noite permanece menos tempo irrigando que durante o dia (Furlani at. al., 1999).

$\mathrm{O}$ autor ainda afirma, que os canais de cultivo são determinantes para o sucesso do NFT. A conformação do canal, sua profundidade e largura, influi na qualidade do produto final e diversos são os tipos de canais que podem ser utilizados.

O material utilizado preferencialmente para os canais e tanque de solução deve ser inerte, desta forma, o mais indicado é o uso de polipropileno, PVC e fibra de vidro (Furlani et al., 1999 e Resh, 1992). Quando o material constituinte dos canais ou tanque de solução não for inerte, é necessário a impermeabilização interna com filme de polipropileno ou material inerte. Por ser a solução nutritiva corrosiva, ela poderá ser contaminada por componentes químicos presentes na constituição destes materiais não inertes (ferro galvanizado e metais leves), tais como $\mathrm{Zn}$ e $\mathrm{Cu}$, alcançando níveis tóxicos para as plantas (Papadopoulos, 1994 e Stoughton, 1969).

Os canais podem ser confeccionados através de telhas de fibrocimento ou filme plástico. A grande limitação é o espaçamento das linhas de cultivo que sempre obedecerão à múltiplos da largura da onda da telha (Furlani et al., 1999). Outra opção é confeccionar canais com plástico dupla face (preto e branco) sobre o solo, com declive de $2 \%$, a face branca fica para fora, enquanto que, a preta fica do lado interno do canal de fundo chato e formato triangular (Furlani et al., 1999 e Resh, 1992).

De acordo com Furlani et al. (1999), os canais de polipropileno são de uso recente, apresentam formato semicircular e são comercializados em tamanhos definidos pelo diâmetro em: pequeno $(50 \mathrm{~mm})$, médio $(100 \mathrm{~mm})$ e grande $(150 \mathrm{~mm})$, já contendo furos para a colocação das mudas no espaçamento escolhido. Apresentam coloração 
interna preta e externa branca. Por ser o polipropileno inerte, dispensam revestimento interno, são mais fáceis de emendar, pois, já vêm com encaixes.

Os canais confeccionados por tubos de PVC e fibrocimento necessitam de cobertura. Esta cobertura tem a finalidade de sustentar a planta, bloquear os raios solares, prevenir contaminação externa e a evaporação da solução (Carmello \& Furlani, 1994). Andriolo (1999) afirma que a evaporação da água da solução altera a concentração da solução e, consequentemente, aumenta sua pressão osmótica, e a incidência de luz na solução permite o aparecimento de algas, as quais competem com as plantas na absorção e utilização de nutrientes. Em cultivos comerciais, placas de isopor tem sido utilizadas com essas quatro finalidades, além de isolante térmico, evitando o aquecimento da solução (Carmello \& Furlani, 1994).

O filme plástico dupla face vem sendo utilizado em vista à substituição do isopor, que além de se quebrar com relativa facilidade também libera, durante sua degradação, um resíduo que contém CFC (cloro flúor carbono), nocivo à camada de ozônio (Furlani et al., 1999).

Andriolo (1999) concorda com Castellane \& Araujo (1995) em relação a importância da entrada da solução no reservatório por queda livre, a fim de aumentar sua aeração.

De acordo com Furlani et al. (1999), o tanque de solução nutritiva deve ser enterrado em local sombreado para impedir o aquecimento da solução, além de ser bem vedado para evitar a formação de algas e entrada de pequenos animais. Sua instalação deve ser feita abaixo do nível da tubulação de drenagem, facilitando o retorno da solução por gravidade.

\subsubsection{Vantagens e Desvantagens}

Andriolo (1999) comenta que a principal vantagem do NFT é a ausência de substrato. Outra vantagem adicional consiste na facilidade pela qual a composição da solução nutritiva pode ser facilmente modificada durante o ciclo da cultura, de forma a ajustá-la às necessidades das plantas. 
Segundo Garcia (1993), o NFT tem a vantagem de não necessitar de aeração suplementar, pois, a circulação da solução promove aeração suficiente para a maioria das culturas. Além disso, não necessita de substrato, pois as plantas ficam diretamente depositadas nos canais de cultivo.

Jones Junior (1983) comenta que o NFT apresenta a vantagem de possibilitar a instalação dos canais nas mais variadas formas, permitindo uma melhor utilização do espaço e facilidade na instalação. Outra vantagem seria o relativo baixo custo dos materiais, pois, os suportes para os canais podem ser confeccionados por madeira ou chapas metálicas. O material do canal quando constituído por tiras de polietileno, podem ser descartados após cada produção, somente necessitando de desinfecção do material permanente e do tanque de solução.

De acordo com Graves (1983), o maior número de cultivos por ano, em função da facilidade de colheita e de replantio, é uma vantagem.

Martinez \& Silva Filho (1997) apresentam como vantagens do NFT o maior rendimento por unidade de área; a melhor qualidade dos produtos; a menor incidência de doenças e pragas, por se ter um ambiente controlado e uma nutrição balanceada; melhor programação da produção; ciclos mais curtos, consequentemente maior número de cultivos por ano; rápido retorno de capital investido e, por fim, melhor aproveitamento dos fertilizantes, reduzindo-se as perdas.

Papadopoulos (1994) afirma que uma das vantagens do NFT é a possibilidade de elevar a temperatura das raízes sempre que necessário, simplesmente, através da solução nutritiva.

Khosla \& Papadopoulos (2001) enfatizam o controle vegetativo através da solução nutritiva de plantas cultivadas em NFT, durante o inverno.

Segundo Adams (1994), o NFT minimiza o desperdício de fertilizantes e a poluição ambiental, pois, o NFT utiliza sistema fechado de circulação da solução nutritiva.

Castellane \& Araujo (1995) relatam a limitação do NFT diretamente relacionado à ocorrência de interrupção temporária no fornecimento da solução nutritiva, caso ocorra qualquer avaria no sistema elétrico ou no conjunto moto-bomba. 
Andriolo (1999) concorda com Graves (1983) e apresenta como desvantagem do NFT a necessidade de conhecimento técnico, pois, o manejo das culturas, em NFT, exige conhecimento básicos de fisiologia vegetal e também sobre o preparo e manejo das soluções nutritivas. A inércia do sistema é quase nula, consequentemente o trabalhador deve estar preparado para tomar decisões rápidas, a fim de resolver problemas eventuais a nível da composição da solução, como da sua distribuição às plantas (Andriolo, 1999).

Quando os cultivos são realizados em ambiente sem o controle da temperatura do ar, fortes variações térmicas ocorrem na solução nutritiva podendo atingir níveis prejudiciais ao crescimento das plantas. O problema é mais sério nos períodos quentes do ano, pois, as canalizações podem funcionar como coletores solares da solução nutritiva atingindo temperaturas consideradas limitantes à atividade das raízes (Andriolo, 1999).

O autor ainda relata como desvantagem do NFT, a dificuldade em suprir corretamente de $\mathrm{O}_{2}$ as raízes de todas as plantas ao longo dos canais, a complexidade técnica e, por fim, as dificuldades operacionais.

Martinez \& Silva Filho (1997) afirmam que os investimentos iniciais elevados e a exigência de alto nível tecnológico (maior conhecimento e preparo do produtor) são desvantagens do NFT.

No NFT, a disseminação de propágulos de patógenos pelo vento, pelo manuseio ou difundido na limpeza do equipamento dá-se planta a planta, havendo poucas possibilidades de controle efetivo (Martinez \& Silva Filho, 1997 e Jones Junior, 1983). O controle de infecções radiculares torna-se difícil porque não há informação sobre o comportamento dos fungicidas em solução, e os produtos disponiveis no mercado foram desenvolvidos para o uso no solo ou em pulverizações sobre as plantas (Martinez \& Silva Filho,1997).

Jones Junior (1983) comenta sobre a morte de raízes, que ocorre nos períodos de elevada demanda de carboidratos, como por exemplo, durante a frutificação e nos períodos de estresse. Quando essa fase cessa, a planta recupera o suprimento 
adequado de carboidratos e novas raizes desenvolvem-se. Acredita-se que este fenômeno ocorra em todos os sistemas de cultivo, mas só no NFT é claramente visível.

\subsection{Solução nutritiva}

\subsubsection{Composição}

De acordo com Martinez (1997), se as plantas, dentro de limites, retiram do meio seletivamente os nutrientes de que necessitam para um desenvolvimento adequado, a concentração de nutrientes na matéria seca de plantas bem nutridas e com boa performance pode servir como ponto de partida para formular uma solução nutritiva para o seu cultivo. Devendo-se manter a proporção dos nutriente da solução nutritiva igual a encontrada na matéria seca da planta.

No cultivo hidropônico tenta-se reproduzir as condições existentes no solo e essenciais ao desenvolvimento das plantas. No entanto, se comparar as concentrações de nutrientes presentes na solução do solo e nas soluções nutritivas, observa-se grandes diferenças. As maiores diferenças dizem respeito à concentração de $\mathrm{P}$, sendo 125 a 675 vezes superiores na solução do solo, seguida da de K (49 a 126 vezes superior ) e, por fim, de N (16 a 56 vezes superior). Para os demais nutrientes, as diferenças são de menor magnitude. Essas diferenças devem-se ao fato do solo apresentar a capacidade de repor nutrientes continuamente para a solução do solo, à medida que são absorvidos pelas raízes (Martinez, 1997).

Winsor (1980) comenta que plantas cultivadas em NFT podem utilizar concentrações de nutrientes muito abaixo daquela tradicionalmente difundida para o cultivo em substratos sólidos. Isso se deve à eficiência da absorção por fluxo de massa, não havendo limitações por difusão, e assim, o monitoramento de nutrientes não é impedido como ocorre em substratos convencionais.

Segundo Adams (1994), a absorção de nutrientes é geralmente proporcional à quantidade de nutrientes disponível para as raízes. No solo, isso pode ser limitado pelo teor de umidade e pH, com efeito na solubilidade de muitos nutrientes. Em 
substrato sólido inerte, a concentração de nutrientes aplicada na solução cai progressivamente entre as irrigações. Em hidroponia com recirculação da solução nutritiva, não há esgotamento local ao redor da superfície das raízes como em solo ou em substratos. Portanto, não há restrição na absorção de nutrientes, e o crescimento ótimo pode ser alcançado mais facilmente.

Ao formular uma solução nutritiva, a proporção de nutrientes presentes no tecido vegetal é a mais utilizada em detrimento da proporção de nutrientes presentes no solo, pois, aquela representa o que a planta conseguiu absorver, e não o que ela tinha à sua disposição no meio nutritivo (Carmello \& Furlani, 1994).

Furlani et al. (1999) comentam que quando se procede à análise das exigências nutricionais das plantas, visando o cultivo em solução nutritiva, deve-se enfocar as relações entre os nutrientes, pois, essa é uma indicação da relação de extração do meio de crescimento. As quantidades totais absorvidas apresentam importância secundária, uma vez que na hidroponia procura-se manter relativamente constante a concentração dos nutrientes na solução nutritiva.

Shippers (1980) ressalta que não é possível fornecer de uma só vez todos os nutrientes, nas quantidades requeridas pela planta, em todo o seu ciclo; uma vez que isso resultaria em concentrações salinas que certamente danificariam as raízes das plantas.

De modo geral, usam-se nas soluções nutritivas concentrações o mais elevada possível, que permitam o crescimento por longo periodo, sem trocas ou readições. No entanto, a concentração máxima possível é limitada pela pressão osmótica, com variações entre espécies e variedades (Martinez, 1997).

Concentrações bastante elevadas de nutrientes são geralmente usadas no NFT para promover uma considerável reserva de nutrientes dentro do sistema, além disso, é muito difícil para monitorar e manter baixas concentrações de nutrientes essenciais por controle da EC, devido a acumulação de sais no fundo do tanque (Winsor, 1980), porém, Hurd ${ }^{3}$ citado por Graves (1983) afirma que, concentrações elevadas de

${ }^{3}$ HURD, R.G. The root and its enveronment in the nutrient film technique of water culture. Acta Horticulturae, n.82, p.87-97, 1978. 
nutrientes são de menor interesse prático, a não ser, que elas necessitem de menor freqüência de manutenção, podendo ser útil em sistemas pequenos com controle manual dos níveis de nutrientes.

Carmello \& Furlani (1994) sugerem a redução da concentração inicial, uma vez que, esta comumente utilizada nas soluções nutritivas, excede em muito a concentração necessária ao desenvolvimento inicial saudável.

Andriolo (1999) afirma que o equilíbrio eletroquímico entre os íons que fazem parte da solução nutritiva devem ser observados, para não perturbar a polarização da membrana celular no nível das raízes. A polarização das membranas influencia o processo de entrada dos nutrientes nas plantas. Assim, a composição da solução nutritiva deve preservar ao máximo o equilibrio das cargas entre os cátions e os ânions.

Stoughton (1969) comenta que as plantas absorvem os nutrientes em estado iônico, pois, cada sal inorgânico, na solução separa-se em duas ou mais partes eletricamente carregadas (cátion e ânion), e são assim absorvidos. Mas, do ponto de vista da planta, o resultado da mistura de nitrato de $\mathrm{K}$ e sulfato de amônia é exatamente equivalente à mistura de nitrato de amônia e sulfato de K. Portanto, a escolha de sais fertilizantes é importante, porque algumas misturas podem promover acúmulo de nutrientes em concentrações elevadas e perigosas, devido a desigual taxa de absorção dos diferentes íons na solução nutritiva.

Para Furlani et al. (1999), a composição ideal de uma solução nutritiva depende não somente das concentrações dos nutrientes, mas também de outros fatores ligados ao cultivo, incluindo o tipo ou o sistema hidropônico.

Com freqüência, busca-se uma formulação ideal, porém as formulações dependem de diversas variáveis que não são controláveis. Desta forma, a solução nutritiva em uso deve ser freqüentemente reajustada. Uma formulação ótima depende das seguintes variáveis (Resh, 1992): espécie e variedade; estado de desenvolvimento da planta; parte da planta a ser colhida ( raiz, folha, fruto e talo); estação do ano - duração do dia; clima - temperatura, intensidade de luz, hora e luminosidade do sol. 
De acordo com Martinez (1997), para o preparo da solução nutritiva podem ser utilizados sais puros ou adubos, observando-se o custo, pureza e solubilidade das várias fontes disponíveis no mercado.

Castellane \& Araujo (1995) concordam com Resh (1992), sobre a importância que deve ser dada as impurezas (material inerte) presentes nos fertilizantes, no momento dos cálculos das necessidades do nutriente para a formulação da solução nutritiva.

Segundo Resh (1992), os diferentes sais fertilizantes que podem ser utilizado na solução nutritiva apresentam diferente solubilidade. A solubilidade é a medida de concentração do sal que permanece na solução quando se dissolve-o em água. Assim, um sal apresenta baixa solubilidade, somente se uma pequena quantidade deste estiver dissolvido em água. Nos cultivos hidropônicos, os sais fertilizantes devem apresentar alta solubilidade, pois, devem permanecer na solução para serem absorvidos pelas plantas.

Castellane \& Araujo (1995) comentam que muitas vezes, para se fornecer um mesmo nutriente, será necessário utilizar mais de uma fonte de fertilizante. Isto ocorre pelo fato de muitas destas fontes fornecerem mais de um nutriente e uma vez fornecida a quantidade total de um deles, determinada fonte não poderá mais ser utilizada.

De acordo com Furlani et al. (1999), quando se utiliza uma única composição da solução nutritiva para o crescimento de variadas espécies vegetais que possuem relação de extração diferentes, há grande possibilidade de desequilíbrio nutricional, seja por acúmulo, seja pela falta de nutrientes ao longo do período de desenvolvimento das plantas. Hewitt ${ }^{4}$ citado por Jones Junior (1982) comenta que, em 1966, já existia listado 160 fórmulas de soluções nutritivas que variam em relação aos vários tipos de sais. Deve-se lembrar, contudo, que teoricamente, cada planta, em cada região, poderá apresentar necessidades diferentes (Castellane \& Araujo, 1995).

\footnotetext{
${ }^{4}$ HEWITT, E.J. Sand and water culture method used in the study of plant nutrition. Kent: Commonwealth Bureau of Growing Plants without Crops, 1966. (Technical Communication, 22).
} 


\subsubsection{Preparo}

Uma vez determinada a composição a ser utilizada, parte-se à etapa de preparo da solução nutritiva.

De acordo com Martinez (1997), a água a ser utilizada para cultivo hidropônico pode ser originária de nascentes, poços ou mesmo da rede urbana de abastecimento. Qualquer que seja sua origem, a sua qualidade deve ser considerada no preparo da solução nutritiva.

Segundo Furlani et al. (1999), a qualidade da água, ou seja, suas características químicas (quantidades de nutrientes e concentração salina) e microbiológicas (coliformes fecais e patógenos) devem ser conhecidas. Muitas vezes, a água é o veículo para a introdução de patógenos e coliformes fecais, portanto, deve-se atentar para sua qualidade microbiológica (Martinez, 1997).

A autora sugere que do ponto de vista da qualidade química, quanto mais pura for a água, melhor sua qualidade. Quanto maior a quantidade de nutrientes nela dissolvidos, maiores as possibilidades de haver desbalanços nutricionais. Desta forma, antes da implantação do cultivo hidropônico, a água a ser utilizada deverá sofrer rigorosa análise e, mesmo após a implantação do sistema, ela deverá ser constantemente monitorada através de análises (Resh, 1992).

Após análise, se a água contiver teores de macro e micronutrientes, respectivamente, superiores a $25 \%$ e $50 \%$ dos valores da fórmula, as quantidades dos nutrientes da solução devem ser recalculados (Furlani et al.,1999). Deve-se atentar ainda para o fato de que a composição da água de nascentes, poços ou rede urbana varia ao longo do ano (Martinez, 1997).

Alguns íons fornecidos na água acumulam-se alcançando em uma semana várias vezes a concentração original na água fornecida, isso porque estes íons, não são removidos pela planta cultivada na mesma proporção que são introduzidos. Inevitavelmente certos íons (particularmente sulfato, sódio e cloreto), acumulados na solução nutritiva com o tempo, podem atingir níveis tóxicos (Asher, 1981). 
Resh (1992) comenta que a dureza da água representa o conteúdo de íons bicarbonato $\left(\mathrm{HCO}_{3}{ }^{-}\right)$que, quando presentes em altas concentrações, afetam diretamente o $\mathrm{pH}$ e a disponibilidade de nutrientes. Normalmente as águas de minas, situadas em camadas de rochas calcárias ou dolomíticas, podem conter niveis altos de $\mathrm{C}$ e de $\mathrm{Mg}$, disponíveis para as plantas, daí o cuidado na formulação da solução nutritiva.

Conforme Benoit (1992), a qualidade da água é um fator decisivo para o sucesso ou o fracasso de cultivos hidropônicos. Os padrões de qualidade da água recomendados para a utilização em hidroponia, são apresentados no Quadro 3.

\begin{tabular}{|c|c|}
\hline Nutrientes & Concentração máxima \\
\hline $\mathrm{Na}$ & 11,5 \\
\hline $\mathrm{Cl}$ & 33,5 \\
\hline $\mathrm{Ca}$ & 80,2 \\
\hline $\mathrm{Mg}$ & 12,2 \\
\hline $\mathrm{SO}$ & 48,1 \\
\hline $\mathrm{HCO}$ & 244,0 \\
\hline $\mathrm{B}$ & 0,00270 \\
\hline $\mathrm{Cu}$ & 0,00063 \\
\hline $\mathrm{Fe}$ & 0,00028 \\
\hline $\mathrm{Mn}$ & 0,00549 \\
\hline $\mathrm{Zn}$ & 0,00327 \\
\hline $\mathrm{F}$ & 0,00475 \\
\hline $\mathrm{CE}$ & \\
\hline
\end{tabular}

Fonte: Adaptado de Benoit, F, (1992).

Quadro 3- Padrões de qualidade da água para hidroponia.

Segundo Carmello \& Furlani (1994), outro fator a ser observado no preparo da solução nutritiva é a pressão osmótica que trata da tendência que a solução nutritiva tem em penetrar nas raízes das plantas, dependendo da quantidade de partículas presentes na própria solução. Sabe-se que a água movimenta-se de uma solução menos concentrada para outra mais concentrada, assim quando adiciona-se sais a água, a pressão osmótica aumenta, isto é, a solução fica mais concentrada e diminui a tendência que a solução tinha de penetrar nas raízes das plantas, de tal forma, que a partir de certa concentração de sais, a tendência passa ser de sair água das células das raízes, promovendo sua morte. Por isso, a solução nutritiva deve conter os nutrientes nas 
proporções adequadas, mas deve também ser suficientemente diluída, para que ela não cause danos as raízes. A pressão osmótica adequada está entre 0,5 e 1 atm ou sua condutividade elétrica (EC) deve estar entre 2 e $3 \mathrm{mS} / \mathrm{cm}$.

Andriolo (1999) afirma que a aeração da solução nutritiva é de extrema importância, pois, as plantas necessitam do fornecimento de oxigênio para a absorção dos nutrientes essenciais ao seu desenvolvimento e para que não ocorra podridões em seu sistema radicular. O fornecimento de oxigênio é feito através de borbulhamento de ar comprimido na solução nutritiva quando o sistema hidropônico é aberto (a solução nutritiva não retorna ao reservatório). Em NFT e aeropônia não há necessidade de aeração extra na solução, pois, a própria circulação do sistema e conseqüente entrada (retorno) por queda livre no tanque de solução promove a aeração (Andriolo, 1999 e Castellane \& Araujo, 1995).

De acordo com Adams (1992), a solubilidade do $\mathrm{O}_{2}$ diminui com a elevação da temperatura, porém, havendo aumento simultâneo na taxa de respiração das raízes e microflora. Consequentemente, a disponibilidade no suprimento de $\mathrm{O}_{2}$ diminui quando a demanda por ele aumenta. A aeração afeta diretamente a absorção de nutrientes, sendo portanto, de crucial importância para o crescimento saudável em solução nutritiva recirculante.

Jun et al. (1999), em pesquisa não verificou efeito estatístico em relação aos perfis aerados ou não aerados nos seguintes parâmetros analisados em melão: formato do fruto, grau de rendilhamento, conteúdo de sólido solúveis, peso do fruto, porém, o peso seco das raízes do meloeiro foi elevada nos perfis com aeração.

Winden (1988) relata que é evidente, em vários experimentos, que temperatura baixa do ambiente radicular inibe a absorção de nutrientes e água.

Segundo Adams (1994), embora a absorção de cátions não tenha sido intimamente relacionada com a temperatura da solução nutritiva, ela geralmente aumenta com a temperatura radicular, estendendo-se entre $14-26^{\circ} \mathrm{C}$.

Castellane \& Araujo (1995) comentam que a faixa da temperatura da solução nutritiva, mais adequada às plantas, é de 20 a $30^{\circ} \mathrm{C}$. Valores extremos, inferiores e superiores, poderão ser atingidos no inverno e verão, respectivamente. 
Para Carmello \& Furlani (1994), a temperatura é considerada adequada até em torno de $30^{\circ} \mathrm{C}$. Os melhores limites de temperatura, para os cultivos de período frio são $16^{\circ} \mathrm{C}$ durante o dia e $10^{\circ} \mathrm{C}$ a noite. Já para o cultivo de período quente é $24^{\circ} \mathrm{C}$ durante o dia e $15^{\circ} \mathrm{C}$ a noite.

É importante salientar que a dissolução dos sais deve ser feita separadamente, evitando assim, reações entre eles (Carmello \& Furlani, 1994). A mistura de solução concentrada de $\mathrm{Ca}\left(\mathrm{NO}_{3}\right)_{2}$ com sulfatos e fosfatos também deve ser evitada, pois pode promover a formação de compostos insolúveis (precipitados) como sulfato de cálcio e fosfato de cálcio (Furlani et al., 1999 e Benoit, 1992).

Sensíveis diferenças na concentração de micronutrientes pode corresponder a um grande erro, pois, a quantidade utilizada é muito pequena. Por outro lado, para os macronutrientes diferenças de 15 a $20 \%$ na quantidade fornecida na solução nutritiva, raramente são significativas (Stoughton, 1969).

\subsection{3 pH}

O mecanismo que controla a acidez ou alcalinidade da solução nutritiva, baseia-se na presença de íons $\mathrm{H}^{+}$e $(\mathrm{OH})^{-}$na solução, os quais são formados pela dissociação de ácidos quando ocorre mistura de ácidos e água $\left(\mathrm{H}^{+}\right)$ou mistura de bases com água $(\mathrm{OH})$.

Carmello \& Furlani (1994) concordam com Graves (1983), valores baixos de $\mathrm{pH}$ provocam competição iônica entre o íon $\mathrm{H}^{+}$e os diversos cátions $\left(\mathrm{NH}_{4}{ }^{+}, \mathrm{K}^{+}, \mathrm{Ca}^{++}\right.$, $\left.\mathrm{Mg}^{++}, \mathrm{Cu}^{++} \mathrm{Fe}^{++}, \mathrm{Mn}^{++}, \mathrm{Zn}^{++}\right)$e valores elevados de $\mathrm{pH}$ diminuem a absorção dos ânions $\left(\mathrm{NO}_{3}^{-}, \mathrm{H}_{2} \mathrm{PO}_{4}^{-}, \mathrm{SO}_{4}^{-{ }^{-}}, \mathrm{Cl}^{-}, \mathrm{MoO}_{4}^{-{ }^{-}}\right)$.

De acordo com Stoughton (1969), o grau de acidez ou alcalinidade da solução nutritiva é medida através do $\mathrm{pH}$. $\mathrm{O}$ pH 7 representa neutralidade e valores abaixo deste, indicam aumento da acidez, enquanto que, valores acima de 7 , representam aumento da alcalinidade. Valores entre pH 6,0 e 6,5, para a maioria das espécies são satisfatórios. Martinez (1997) e Papadopoulos (1994) discordam e consideram como adequado em soluções nutritivas o pH entre 5,5 e 6,5. Sua manutenção nessa faixa 
assegura boa disponibilidade de macro e micronutrientes e crescimento contínuo das plantas.

Wilcox (1982) afirma que $\mathrm{pH}$ inferior a 4 pode resultar em graves perdas de cultivo, devido a danificações nas raízes, pelos íons $\mathrm{H}^{+}$da solução nutritiva. A integridade das membranas são afetadas, podendo haver perda de nutrientes já absorvidos (Martinez, 1997).

Em $\mathrm{pH}$ superior a 7 , podem ocorrer reações entre $\mathrm{Ca}$ e fosfato, ou $\mathrm{Ca}$ e sulfatos. Os micronutrientes, por sua vez, podem formar hidróxidos e ter sua disponibilidade reduzida (Martinez, 1997), a disponibilidade de Fe é afetada (Wilcox, 1982).

Castellane \& Araujo (1995) comentam que as plantas toleram maior amplitude de $\mathrm{pH}$ em hidroponia, quando comparado com o cultivo em solo.

Furlani et al. (1999) sugerem que grande parte das soluções nutritivas não tem capacidade tampão, e o pH não se mantém dentro da faixa ideal, varia continuamente com a absorção dos íons por parte da planta, portanto, o pH deve ser monitorado diariamente. $\mathrm{O}$ ajuste do $\mathrm{pH}$ pode ser feito por meio de adição de ácidos (sulfúrico, fosfórico, clorídrico ou nítrico) quando se quer abaixar o $\mathrm{pH}$ ou bases (hidróxido de potássio, de sódio ou de amônio) quando a finalidade é elevar o $\mathrm{pH}$.

De acordo com Graves (1983), a absorção desigual dos íons pela planta e adição de água para reposição do volume perdido, geralmente aumentam o $\mathrm{pH}$ da solução e a utilização de ácidos que contenham elementos essenciais $\left(\mathrm{NHO}_{3}, \mathrm{H}_{2} \mathrm{SO}_{4} \mathrm{e}\right.$ $\mathrm{H}_{3} \mathrm{PO}_{4}$ ), pode promover um acúmulo de nitrato, sulfato ou fosfato, íons estes que contribuirão para aumentar a salinidade da solução, e se esta for monitorada por uma EC constante, as medidas ficarão mascaradas havendo necessidade de aumentar a EC com o tempo, ou efetuar a troca da solução por uma nova ou ainda aumentar o volume de solução por planta.

Tanto os ácidos quanto os álcalis que contenham um ou mais nutrientes essenciais são menos recomendados do que aqueles que não os contenham. Desse modo, o hidróxido de sódio e o ácido clorídrico são, respectivamente, o álcali e o ácido preferidos para o ajuste do pH (Blíska Júnior \& Honório, 1997 e Jones Junior, 1983). 
Papadopoulos (1994) comenta que, quando uma significativa quantidade de $\mathrm{N}$ é fornecida através da $\mathrm{NH}_{4}$ e a capacidade tampão da água é baixa, o pH pode cair abaixo de valores aceitáveis. $\mathrm{O}$ inverso ocorre quando a principal fonte de $\mathrm{N}$ é o $\mathrm{NO}_{3}$, podendo a solução nutritiva elevar durante o cultivo.

Mortley et al. (2001) verificaram em pesquisa com batata-doce em NFT forte declínio do $\mathrm{pH}$ da solução nutritiva. Este fenômeno pode ser observado em muitos experimentos conduzidos em NFT, exceto quando, a única fonte de $\mathrm{N}$ é na forma de $\mathrm{NO}_{3}$. Presumidamente, esta redução no $\mathrm{pH}$, é um reflexo do balanço de trocas da planta, por causa, da presença de $\mathrm{N}$ na forma de $\mathrm{NH}_{4}$. Plantas nutridas com $\mathrm{NH}_{4}$ são caracterizadas por uma alta relação cátio:ânion absorvidos, resultando num efluxo de $\mathrm{H}^{+}$ das raízes, consequentemente abaixando o pH da solução nutritiva (Marschner, 1995).

Para Martinez (1997), a variação no $\mathrm{pH}$ é proporcional ao volume do crescimento da planta, e inversamente proporcional ao volume do tanque. Isto significa que planta de crescimento mais lento poderão ser conduzidas por mais tempo na mesma solução, pois proporcionam menor variação no $\mathrm{pH}$. Já as plantas com grande velocidade de crescimento proporcionaram grandes alterações no $\mathrm{pH}$ da solução sendo necessário mais de uma correção diária.

Graves (1983) recomenda que se façam leituras e correções diárias para o caso do controle manual do $\mathrm{pH}$. Jones Junior (1983) sugere que se monitore continuamente e se adicione ácido ou base conforme a necessidade de ajuste no $\mathrm{pH}$ da solução nutritiva.

\subsubsection{Condutividade elétrica (EC), reposição e troca}

De acordo com Andriolo (1999), a EC de uma solução indica a quantidade de sais solúveis que ela contém, assim uma queda na EC é acompanhada por uma queda proporcional na quantidade total de íons disponíveis para a absorção por parte das raízes.

Resh (1992) afirma que a EC é utilizada geralmente como parâmetro para a tomada de decisão do momento da troca da solução nutritiva ou reposição dos sais, 
porém, não se trata de um parâmetro preciso, uma vez que indica a quantidade total de sais e não a quantidade de cada sal presente na solução.

Graves (1983) comenta que a EC é quase inalterada por quantidades de micronutrientes normalmente presentes na solução nutritiva.

A EC deve ser monitorada diariamente, após o tanque ser completado com água até o valor inicial. Como recomendação geral, para o NFT, quando o valor cai abaixo de 2,0 mS/cm, nutrientes são adicionados para manter o valor entre 2,0 e 3,0 mS/cm (Martinez, 1997 e Castellane \& Araujo, 1995). Contudo, deve-se estar atento para as exigências de cada cultura (Castellane \& Araujo, 1995).

Martinez (1997) concorda com Resh (1992) e sugere que a faixa de concentração usada normalmente, para EC varia entre 2 e $4 \mathrm{mS} / \mathrm{cm}$, níveis de sais acima de $4 \mathrm{mS} / \mathrm{cm}$ podem levar a murcha da planta, detendo o desenvolvimento e ressecando os frutos (Resh, 1992).

Franco et al. (1993) verificaram que EC de $5 \mathrm{mS} / \mathrm{cm}$ em solução nutritiva tem pequeno efeito na produtividade do melão sob cultivo protegido em potes de PVC com silica e areia, e não afeta as características organolépiticas dos frutos.

Khosla \& Papadopoulos (2001) observaram que a EC da solução nutritiva tem significativa influência na absorção de nutrientes.

Adams (1994) cultivando tomate e pepino em NFT observou que o aumento da salinidade em NFT, reduz a absorção de água e restringe o crescimento da planta. Desta maneira, salinidade de 6 a $8 \mathrm{mS} / \mathrm{cm}$ pode ser usada para o controle do vigor vegetativo de plantas de tomate sob deficiente condições de iluminação. Elevada salinidade é geralmente evitada para culturas mais sensíveis, tais como o pepino.

O controle do crescimento de plantas em ambiente protegido pode ser obtido por ajuste da salinidade da solução nutritiva (EC), assim como a composição da própria solução nutritiva aplicada (Schwartz \& Kuchenbuch, 1997 e Tremblay \& Senecal, 1988).

Segundo Andriolo (1999), quanto maior for o volume de solução nutritiva por planta, menor será as alterações na concentração dos nutrientes e portanto na EC, além disso proporcionará maior contato entre sistema radicular e nutriente. 
Castellane \& Araujo (1995) afirmam que para o conhecimento exato dos nutrientes presentes na solução e sua quantidade, deve-se fazer o uso de análise química, ela permitirá visualizar os íons que estão em excesso por serem absorvidos em menores quantidades ou íons que estão em falta.

De acordo com Furlani et al. (1999), na fase inicial de desenvolvimento das plantas, deve-se utilizar soluções diluídas a $50 \%$ do total de sais utilizados na fase de pleno desenvolvimento. Deve-se ter em mente que o crescimento da planta e a demanda por nutrientes aumenta exponencialmente com o tempo, portanto, os intervalos entre trocas ou readições devem reduzir-se com o aumento da taxa de crescimento da planta (Martinez, 1997).

Castellane \& Araujo (1995) comentam que, em qualquer sistema hidropônico, é muito importante que a água que sai do sistema (evaporação, absorção e transpiração pela planta) tenha seu volume reposto diariamente, pois, é sabido que as plantas absorvem mais água que nutrientes (Martinez, 1997). Caso não ocorra a reposição da água, os nutrientes se concentrar-se-ão e em situações extremas, podem causar problemas de salinidade e prejudicar o crescimento das plantas (Castellane \& Araujo, 1995).

Schwarz et al. (2001) relatam que o controle da EC da solução nutritiva no ambiente radicular é mais complicado do que parece. $\mathrm{O}$ fornecimento da solução nutritiva, com EC constante, resulta em mudanças na EC da solução no ambiente radicular, porque as plantas não absorvem nutrientes e água na mesma proporção, promovendo deficiência nutricional ou enriquecimento de sais no ambiente radicular. Normalmente a EC do meio radicular é maior do que a EC da solução nutritiva. $\mathrm{O}$ controle da EC do ambiente radicular é feito através da EC da solução nutritiva e pela quantidade de solução fornecida para as plantas.

Segundo Martinez (1997), a troca da solução nutritiva impede o acúmulo de certos nutrientes, não absorvidos na mesma proporção que os demais, que poderiam interagir negativamente na absorção ou causar toxidez por isso. A readição de sais não é recomendada por períodos maiores que 2 a 3 meses. O problema é mais sério para os micronutrientes, já que para esse, o limite entre carência e toxidez é estreito. 
Furlani et al. (1999), considerando o fato da absorção de nutrientes pelas plantas ser seletiva em função da planta, comentam que a reposição dos nutrientes durante o desenvolvimento das plantas, sem afetar o balanço entre as suas concentrações na solução nutritiva, passa a ser o maior desafio dos produtores do cultivo hidropônico.

Diferentes formas de reposição de nutrientes são mencionadas na literatura.

No início, procurava-se renovar periodicamente a solução nutritiva, entretanto, essa prática, além de desperdícios, causa o efeito poluente (Furlani et al., 1999; Adms, 1994 e Adams, 1992).

Martinez (1997) sugere completar o volume consumido de solução diariamente com água e medir a EC. Quando esta atingir o valor limite estabelecido $(50 \%, 30 \%$ da quantidade total de íons adicionada) efetua-se a troca ou readição. Outra maneira é repor diariamente a solução nutritiva na quantidade equivalente a que foi reduzida do tanque (Furlani ${ }^{5}$ ).

Pardossi et al. (2000) relatam que, para impedir mudanças indesejadas na concentração da solução nutritiva, ajustes semanais do conteúdo mineral devem ser propostos e a cada 2-3 semanas a completa substituição da solução nutritiva.

De acordo com Resh (1992), no NFT a vida útil da solução nutritiva é de 2 a 3 semanas, dependendo da estação do ano e do estado de desenvolvimento da planta. Durante os meses de verão, na planta com frutificação, pode ser necessário a troca semanal da solução. Isto devido a diferente absorção dos nutrientes pelas plantas.

O autor comenta ainda que nunca deve-se utilizar a solução nutritiva por um espaço de tempo maior que 3 meses sem que se efetue uma troca completa da solução, efetuando-se também uma lavagem com água limpa de todo o sistema, inclusive as bancadas. A vida útil da solução que tenha sido ajustada semanalmente, por meio de análises semanais, é de 2 meses. No caso das soluções onde não foram realizadas análises, a vida útil não deve exceder de 2 a 3 semanas.

\footnotetext{
${ }^{5}$ FURLANI, P.R. (IAC. Seção Fertilidade do solo, Campinas). Comunicação pessoal, 2001.
} 
Papadopoulos (1994) comenta que a freqüência para remoção da solução nutritiva depende da fase de crescimento da planta e estação do ano, ambos afetam as taxas de absorção de nutrientes e água pela cultura. Geralmente a remoção da solução nutritiva é mensal para o início do cultivo e duas vezes ao mês, quando o cultivo já esta estabelecido. Após o ganho de experiência em NFT, a solução nutritiva pode necessitar de menor freqüência de remoção.

Segundo Carmello \& Furlani (1994), a troca da solução nutritiva é feita em função da taxa de crescimento da planta, do volume de solução colocado à disposição das plantas e da variação de concentração e do pH, que essa utilização de solução nutritiva permita.

Staff (1998) afirma que quanto maior o número de plantas, maior será a absorção de nutrientes e logo existe a necessidade de reposição dos nutrientes com mais freqüência.

Castellane \& Araujo (1995) relatam que no NFT a vida útil da solução nutritiva é de 3 a 4 semanas, dependendo da estação do ano e do estádio de desenvolvimento das plantas, da população de plantas e do volume do reservatório. Sempre que possível, é importante fazer-se análise da solução; isto levará ao conhecimento dos íons que estão se acumulando e que podem atingir níveis tóxicos, como o acúmulo de cloreto, $\mathrm{Cu}$ e Zn.

\subsection{Relação potássio e nitrogênio (K:N)}

\subsubsection{Absorção de nutrientes}

De acordo com Belfort et al. (1986a), o crescimento inicial do meloeiro é lento nos primeiros 15 dias, vindo intensificar-se a seguir, ocorrendo maior incremento entre 30 e 45 dias após a emergência, próximo ao início do florescimento. Já Tyler \& Lorenz (1964) constataram maior intensidade de crescimento entre 70 e 80 dias de idade da planta. Esta fase coincide também com o início do florescimento. 
Belfort at al. (1986a) comentam que os frutos contribuem em cerca de $50,3 \%$ do total de matéria seca acumulada e a época de maior demanda de nutrientes compreende o período de 45 a 60 dias após a emergência.

Conforme Rincón Sanchez et al. (1998), a quantidade de K acumulada na colheita pelo fruto corresponde a $71,7 \%$ do total acumulado, enquanto, que para o nitrogênio $61,2 \%$.

Kano et al. (1981) afirmam que o $\mathrm{N}$ absorvido pelo meloeiro, a partir de 30 dias após polinização até a colheita é principalmente absorvido pelo fruto.

A composição química da casca e polpa, das sementes e do fruto inteiro encontram-se no Quadro 4. O K seguido do $\mathrm{N}$ estiveram presentes em maior proporção no conjunto casca e polpa (Belfort et al., 1986a).

\begin{tabular}{|c|c|c|c|}
\hline Nutrientes (\%) & Casca e polpa & Sementes & Fruto inteiro \\
\hline $\mathrm{N}$ & 2,11 & 4,03 & 2,34 \\
\hline $\mathrm{P}$ & 0,32 & 0,75 & 0,43 \\
\hline $\mathrm{K}$ & 3,17 & 2,68 & 3,47 \\
\hline $\mathrm{Ca}$ & 0,19 & 0,06 & 0,19 \\
\hline $\mathrm{Mg}$ & 0,30 & 0,32 & 0,31 \\
\hline $\mathrm{S}$ & 0,11 & 0,13 & 0,12 \\
\hline
\end{tabular}

Fonte: Belfort at al. (1986a).

Quadro 4 - Concentrações médias de nutrientes na polpa e casca, nas sementes e no fruto inteiro de melão.

Segundo Gómez-Guillamón et al. (1997), as necessidades de nutrientes pelo meloeiro são diferentes nos distintos estádios de desenvolvimento. Durante o desenvolvimento radicular até a floração tem grande importância o $\mathrm{P}$ e o fornecimento de nutrientes em pequenas quantidades para favorecer o enraizamento e a floração. Da floração ao enchimento dos frutos, deve-se fornecer $\mathrm{P}$ e $\mathrm{K}$ evitando os excessos de $\mathrm{N}$, que favorece o desenvolvimento vegetativo. Entre o enchimento do fruto e o crescimento final da planta é a fase onde a planta demanda mais nutrientes, especialmente o $\mathrm{N}, \mathrm{K}, \mathrm{Mg}$ e o Ca. Quando os frutos estiverem formados e até sua completa maturação, as necessidades de nutrientes diminuem consideravelmente. 
Entretanto, deve-se aumentar as quantidades de $\mathrm{K}$ para favorecer a qualidade ao fruto Palomar $^{6}$ citado por (Gómez-Guillamón et al., 1997). O K, ainda, influencia favoravelmente na coloração da casca e na firmeza do fruto ( Malavolta \& Crocomo, 1982).

De acordo com Filgueira (2000), o meloeiro é altamente exigente em nutrientes. Experimentalmente, o P tem sido o macronutriente que proporciona maiores respostas em produtividade, seguido do N. Entretanto, o K melhora a qualidade dos frutos, inclusive o sabor.

Arnon (1966) comenta que a adubação potássica, geralmente aumenta a eficiência da adubação nitrogenada, e em conjunto com $\mathrm{P}$, neutraliza o efeito desfavorável dos níveis excessivos do $\mathrm{N}$, acentuando a qualidade das proteínas. A deficiência do $\mathrm{K}$ leva à distúrbios no metabolismo de $\mathrm{N}$, resultando em plantas com maior conteúdo de compostos solúveis de $\mathrm{N}$ e aminoácidos livres.

Segundo Kagohashi et al. (1981), em cultivo de melão em sistema Kuntan, usando casca de arroz carbonizada, o incremento em qualidade dos frutos é alcançado com a utilização de reduzida absorção de nutrientes durante a fase inicial de desenvolvimento dos frutos e nos 10 dias anteriores à colheita.

Conforme Furlani et al. (1999), culturas que possuem fase reprodutiva com interesse comercial na produção de frutos, a relação entre $\mathrm{N}, \mathrm{K}$ e P considerada deve ser diferente da usada para o desenvolvimento vegetativo. No período de floração e frutificação, deve-se reduzir a relação $\mathrm{N} / \mathrm{K}$ e aumentar $\mathrm{P} / \mathrm{K}$. Essas alterações são de fácil realização no cultivo hidropônico.

Os autores ainda apresentam relações entre os teores foliares $(\mathrm{g} / \mathrm{kg})$ de macronutrientes com teores de $\mathrm{K}$ considerados adequados para a cultura do meloeiro em desenvolvimento vegetativo adequado (Quadro 5). É interessante lembrar que existe diferenças nos teores de nutrientes em folhas em função do cultivar, da época de amostragem e da posição das folhas.

\footnotetext{
${ }^{6}$ PALOMAR, F. Fertirrigacíon de cultivos hortícolas en invernadero. Hoja Divulgadora 15 , Consejería de Agricultura y Pesca de la Junta de Andalucía, 1992.44p.
} 


\begin{tabular}{|c|c|c|c|c|c|c|}
\hline Cultura & $\mathrm{K}$ & $\mathrm{N}$ & $\mathrm{P}$ & $\mathrm{Ca}$ & $\mathrm{Mg}$ & $\mathrm{S}$ \\
\hline Melão & 1,00 & 1,14 & 0,14 & 1,14 & 0,29 & 0,08 \\
\hline
\end{tabular}

Fonte: Adaptado de Furlani et al. (1999).

Quadro 5- Relações entre os teores foliares $(\mathrm{g} / \mathrm{kg})$ de $\mathrm{N}, \mathrm{P}, \mathrm{K}, \mathrm{Ca}, \mathrm{Mg}$,

e $\mathrm{S}$ com teores de $\mathrm{K}$ considerados adequados para a cultura do meloeiro.

\subsubsection{Absorção de nutrientes em hidroponia}

Rincón Sanchez (1997) concorda com Martinez (1997) e Carmello \& Furnali (1994), os autores afirmam que, de todos os órgãos vegetativos da planta, as folhas promovem informação precisa da absorção de nutrientes. Os Quadros 6 e 7 apresentam valores de referência sobre a concentração mineral em folhas do meloeiro.

\begin{tabular}{|c|c|c|c|}
\hline Macronutrientes & (\%) sobre matéria seca & Micronutrientes & $(\mathrm{ppm})$ \\
\hline $\mathrm{N}$ & $4,00-4,30$ & $\mathrm{Fe}$ & $209-228$ \\
\hline $\mathrm{P}$ & $0,67-0,76$ & $\mathrm{Mn}$ & $87-94$ \\
\hline $\mathrm{K}$ & $2,25-2,44$ & $\mathrm{Cu}$ & $40-47$ \\
\hline $\mathrm{Ca}$ & $4,50-4,87$ & $\mathrm{Zn}$ & $26-34$ \\
\hline $\mathrm{Mg}$ & $1,39-1,47$ & $\mathrm{~B}$ & $20-29$ \\
\hline
\end{tabular}

Fonte: Rincón Sanchez (1997).

Quadro 6- Concentração mineral em folha de melão.

\begin{tabular}{|c|c|c|c|c|c|}
\hline \multirow{2}{*}{$\begin{array}{c}\text { Dias após } \\
\text { transplante }\end{array}$} & \multicolumn{5}{|c|}{ Macronutrientes (\% sobre matéria seca) } \\
\cline { 2 - 6 } & $\mathrm{N}$ & $\mathrm{P}$ & $\mathrm{K}$ & $\mathrm{Ca}$ & $\mathrm{Mg}$ \\
\hline 0 & 4,44 & 0,35 & 4,23 & 2,15 & 1,25 \\
\hline 35 & 4,57 & 0,45 & 2,99 & 7,35 & 1,60 \\
\hline 65 & 3,31 & 0,25 & 3,00 & 8,08 & 1,96 \\
\hline 85 & 3,14 & 0,27 & 2,96 & 7,27 & 1,89 \\
\hline 105 & 3,09 & 0,31 & 2,68 & 7,09 & 1,86 \\
\hline 125 & 3,25 & 0,32 & 2,52 & 7,01 & 1,83 \\
\hline
\end{tabular}

Fonte: Rincón Sanchez (1997).

Quadro 7-Evolução da concentração de macronutrientes em folhas de melão.

Segundo Raij et al. (1997), os níveis de concentração de nutrientes em folhas sadias de melão estão na faixa de 2,30 a $3,30 \%$ de N; 0,28 a 0,62 de $P ; 2,53$ a 
$2,87 \%$ de K; 2,59 a 5,14 de Ca; 0,79 a $0,99 \%$ de $\mathrm{Mg}$ e 0,22 a $0,24 \%$ de S. Para folhas de melão com sintomas de carência nutricional Belfort et al. (1986b) constataram 1,11 a $2,21 \%$ de $\mathrm{N} ; 0,12$ a $0,23 \%$ de $\mathrm{P} ; 0,86$ a $1,76 \%$ de $\mathrm{K} ; 0,85$ a $2,22 \%$ de $\mathrm{Ca} ; 0,60$ a $0,71 \%$ de $\mathrm{Mg}$ e 0,71 a $0,19 \%$ de $\mathrm{S}$.

Furlani et al. (1999) apresentam uma série de concentrações de nutrientes recomendados por diversos autores para formulação de soluções nutritivas para o cultivo de melão em hidroponia.

Pardossi et al. (1994) realizaram 2 ensaios em NFT, conduzidos na primavera e verão de 1992. Foram avaliados 2 soluções nutritivas diferentes para cada estação do ano, com relação K:N (1,7:1; 3,08:1 e 3,4:1) distintas.

Os autores verificaram que o aumento da concentração da solução nutritiva afetou o total de $\mathrm{N}$ e $\mathrm{K}$ absorvido, além disso a estação do ano também influenciou na absorção dos nutrientes, ou seja, a absorção de $\mathrm{K}$ foi maior no verão do que na primavera, embora a EC da solução nutritiva fosse menor.

Os autores ainda comentam que a absorção de $\mathrm{N}, \mathrm{K}$ e Ca foi maior no verão e que os nutrientes absorvidos $(\mathrm{N}, \mathrm{P}$ e $\mathrm{K})$ atingiram altas taxas durante a frutificação, diminuindo após o início da colheita na primavera, ao passo, que permaneceram inalterados no verão.

Bernadac et al. (1996), trabalhando com melão em NFT, concluíram que o K é altamente móvel no floema e é fornecido durante todo o desenvolvimento do fruto, ao contrário do $\mathrm{Ca}$, o qual é acumulado principalmente durante os primeiros 20 dias do desenvolvimento do fruto, podendo ser relacionado à sua baixa mobilidade no floema.

Pardossi et al. (1995), no ensaio em NFT avaliando 8 soluções nutritivas com diferentes relações $\mathrm{K}: \mathrm{N}(1,7: 1 ; 2,25: 1 ; 2,62: 1 ; 3,08: 1$ e 3,4:1) e diferentes EC ( 2.3 ; $2.7 ; 2.8 ; 2.9 ; 3.0 ; 3.1$ e $3.4 \mathrm{mS} / \mathrm{cm})$, verificaram que em ambas estações o meloeiro mostrou abundante crescimento vegetativo e não apresentou sintomas de deficiência nutricional. A produtividade não foi influenciada pela composição da solução nutritiva, nem pela absorção total de macronutrientes, mas a produtividade pareceu ser influenciada pela estação do ano (primavera e verão). 


\section{MATERIAL E MÉTODOS}

\subsection{Condições experimentais}

O experimento foi conduzido na área experimental do Departamento de Produção Vegetal da Escola Superior de Agricultura "Luiz de Queiroz" (ESALQ), USP, localizada em Piracicaba, SP, no período 04/01/2001 a 12/04/2001. As condições meteorológicas nesse periodo, registradas na Estação Meteorológica do Departamento de Ciências Exatas da ESALQ, constam no Anexo A.

A execução do experimento realizou-se inicialmente em ambiente protegido. Utilizou-se uma estrutura de cobertura plástica de $50 \mathrm{~m}^{2}$, com $2,80 \mathrm{~m}$ de pé direito e 4,30m de altura no ponto mais alto da curvatura do arco. $\mathrm{O}$ fechamento lateral e frontal foi confeccionado por tela de polipropileno branca. Sob a estufa foram montadas duas bancadas de madeira nas quais repousavam os canais recipientes (perfis) de polipropileno, apresentando $43 \mathrm{~mm}$ de profundidade e $100 \mathrm{~mm}$ de largura, nos quais fluia a solução nutritiva. $O$ espaçamento entre orifícios do perfil para a deposição das mudas foi $10 \mathrm{~cm}$.

Cada bancada continha 10 perfis colocados a uma distância mínima de $0,85 \mathrm{~m}$ do solo, de modo que ficassem com $2 \%$ de declividade para possibilitar o retorno da solução nutritiva ao tanque de abastecimento.

Os perfis próprios para o NFT eram internamente de coloração preta, para que não houvesse desenvolvimento de algas e externamente brancos na parte superior, para que evitasse a elevação da temperatura da solução nutritiva. 
O tanque de solução nutritiva, constituído de fibra de vidro e com capacidade de $250 \mathrm{~L}$, foi instalado externamente à estufa e enterrado no solo para evitar a elevação da temperatura da solução nutritiva.

Também foi instalado um temporizador (timer) para controlar o tempo de funcionamento da bomba, acionada com motor de $0,5 \mathrm{cv}$ de potência.

Todo o solo da estufa foi recoberto com serragem para que o local sempre estivesse livre de plantas daninhas. $\mathrm{Na}$ antecâmara foi instalado uma caixa contendo cal.

Para a condução das mudas já formadas, utilizou-se um segundo ambiente protegido de cobertura plástica com $350 \mathrm{~m}^{2}$ de área útil e $15,0 \mathrm{~m}^{2}$ de área para o armazenamento dos tanques de solução nutritiva, apresentando ainda um compartimento de $5,5 \mathrm{~m}^{2}$ para o armazenamento e prepara das soluções estoque. $\mathrm{O}$ ponto mais alto na curvatura do arco apresentava $4,30 \mathrm{~m}$ de altura e o pé direito $2,80 \mathrm{~m}$. O fechamento lateral e frontal foi de tela de polipropileno preto a $30 \%$, com proteção lateral (saia) de 1,0m acima do solo para evitar que respingos de chuva e solo contaminasse a solução nutritiva.

$\mathrm{Na}$ cobertura do ambiente protegido foi instalado três sistemas para a exaustão do ar quente, ou seja, saída de ar coberta com tela de polipropileno branca recoberta a $20 \mathrm{~cm}$ de distância superficialmente por plástico transparente.

Para a condução definitiva das plantas, foram utilizados canais recipientes (perfis) de PVC, de 6", colocados a uma distância mínima de $0,20 \mathrm{~m}$ do solo, de modo que ficassem com 3\% de declividade, para possibilitar o retorno da solução nutritiva ao tanque de origem. Os perfis apresentavam coloração preta internamente e branca externamente, evitando assim, o desenvolvimento de algas e o aumento da temperatura da solução nutritiva. A vazão utilizada para a entrada da solução nutritiva nos perfis, foi $10 \mathrm{~L} / \mathrm{min} /$ perfil.

Estruturas de metal, colocadas a cada $2,50 \mathrm{~m}$ de distância, serviram de suporte para a sustentação dos perfis. Utilizou-se 8 linhas de perfis, interrompidas no abastecimento, a cada $9,0 \mathrm{~m}$, porém interligadas no retorno, formando assim 5 blocos com 8 linhas de perfis, com 9,0m cada. Através da Figura 1 é possível visualizar o croqui da área experimental. Para cada 2 linhas foi utilizada um tanque de solução 

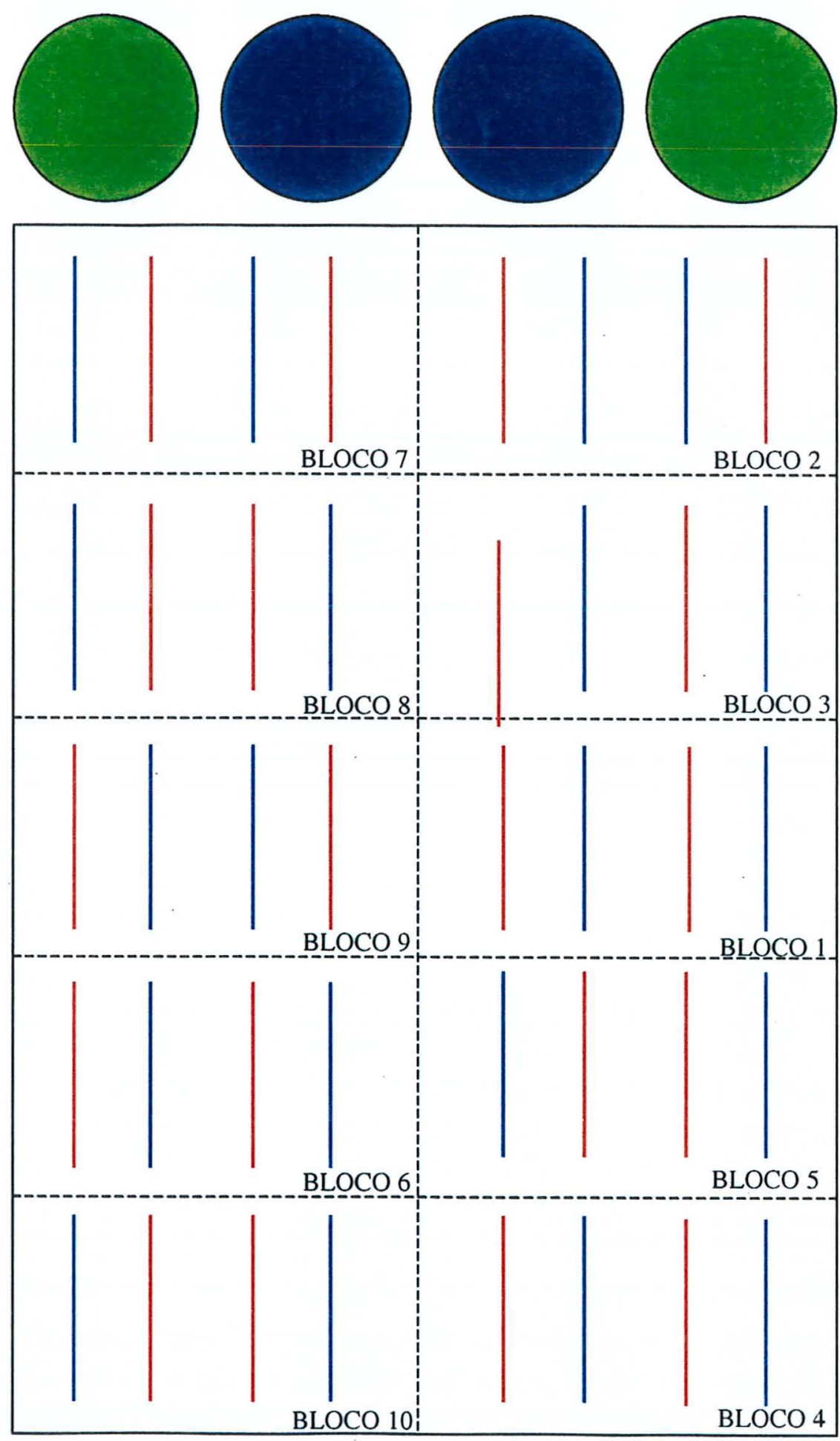

Figura 1- Croqui da área experimental (módulo de $350 \mathrm{~m}^{2}$ ) 
nutritiva de $1.500 \mathrm{~L}$, constituído por fibra de vidro. Estes tanques foram colocados em um nível abaixo dos perfis, para que fosse possível o retorno da solução nutritiva por gravidade.

Todo o solo do ambiente protegido foi recoberto com pedrisco para que o local sempre estivesse livre de plantas daninhas e para que partículas do solo não contaminassem a solução nutritiva.

O sistema para o tutoramento do meloeiro foi montado com arame Frutifio $^{(B)}$ ondulado tencionado a uma altura de $2,10 \mathrm{~m}$ do solo.

Para a alimentação dos tanques de solução nutritiva, foi instalado externamente ao ambiente protegido uma caixa de água com capacidade de $10.000 \mathrm{~L}$ e confeccionada por fibra de vidro.

$\mathrm{Na}$ alimentação das 8 linhas de perfis, um conjunto composto por 8 motobombas com potência de $0,5 \mathrm{cv}$ cada, foi utilizado. Também utilizou-se um temporizados (timer) com a finalidade de controlar o tempo de funcionamento das bombas.

\subsection{Delineamento e fatores analisados}

O delineamento adotado foi em blocos ao acaso. Foram estudados duas diferentes soluções nutritivas (com relação $\mathrm{K}: \mathrm{N}$ ) para dois híbridos distintos. Utilizou-se 10 repetições, representadas pelos blocos.

Cada parcela experimental foi composta por 72 plantas perfazendo um total de 720 plantas. Foi adotado o espaçamento de $0,50 \mathrm{~m}$ entre plantas e $0,80 \mathrm{~m}$ entre linhas (perfis), avaliando-se 20 plantas (10 plantas de cada híbrido) por parcela. Como para cada planta avaliada analisou-se 2 frutos, ou seja, no total analisaram-se 40 frutos (20 frutos de cada híbrido) por parcela.

As diferentes soluções nutritivas utilizadas foram:

- Solução 1: relação $\mathrm{K}: \mathrm{N}=1,3: 1$ do início ao fim do ciclo

- Solução 2: relação $\mathrm{K}: \mathrm{N}=1,3: 1$ até o início da frutificação e 2,6:1 até o fim do ciclo. 
Vale salientar que na solução 2 , o K foi complementado através de $50 \%$ de $\mathrm{KSO}_{4}$ e $50 \%$ de $\mathrm{KCl}$, quando a planta iniciou a frutificação. Com isso, realizou-se a mudança de solução nutritiva quando a planta já estava em fase reprodutiva, concordando com Gómez-Guillamón et al. (1997), que no momento da fase reprodutiva deve-se fornecer mais $\mathrm{K}$ e $\mathrm{P}$ evitando os excesso de $\mathrm{N}$.

Os híbridos de melão nobre utilizados no experimento foram:

- Híbrido 1: denominado Orange Flesh, melão tipo Honey Dew da Empresa Sakata Seed Sudamérica Ltda.

- Híbrido 2: denominado Galileo, melão tipo Galia da Empresa Rogers Seeds.

A classificação comercial por tipo facilita a comunicação entre os diferentes agentes da cadeia do agronegócio do melão. Por tipo deve ser entendido um grupo de cultivares ou de híbridos que apresentam uma ou mais características semelhantes, identificáveis facilmente e diferenciadas dos demais, tal como, o aspecto da casca (cor quando maduro, presença ou ausência de suturas, cicatrizes, reticulação ou rendilhamento), cor da polpa, formato do fruto entre outros (Alves, 2000).

O melão tipo Honey Dew é de origem norte-americana, caracteriza-se por apresentar forma semi-oblonga, casca lisa de cor verde clara que evolui para esbranquiçada quando maduro (Sobrino Illescas \& Sobrino Vesperinas, 1989). Não desenvolve zona de abcisão após o fruto ter alcançado a máxima concentração de açúcares (Webster, 1975). A polpa do híbrido Orange Flesh passa de verde para salmão a medida que vai desenvolvendo a maturação.

O melão tipo Galia é de origem israelense caracteriza-se por apresentar forma redonda, casca de cor verde que evolui para amarela quando maduro (Torres, 1997). Notadamente reticulado (cicatrizes nos sentidos longitudinal e transversal formando uma malha). Separa-se facilmente do pedúnculo quando maduro (Zapata et al., 1989). A polpa é verde clara e a textura é mantegosa (Torres, 1997). O híbrido Galileo é extremamente aromático. 


\subsection{Instalação e condução do experimento}

\subsubsection{Produção das mudas}

Para a germinação de sementes através do NFT, foi empregado espuma de resina fenólica, sendo um substrato estéril, de fácil manuseio e que oferece ótima sustentação para as plântulas (Furlani et al., 1999).

A espuma de resina fenólica utilizada foi a Green up $^{\circledR}$ em placas com células de $25 \times 25 \mathrm{~mm}$ e $38 \mathrm{~mm}$ de altura.

Seguiu-se os procedimentos recomendados por Furlani et al. (1999):

- Dividir a placa de espuma de resina fenólica ao meio;

- Lavar (enxaguar) em água limpa diversas vezes para eliminar possíveis compostos ácidos remanescentes de sua fabricação.

- Para evitar que a placa de espuma se quebre, usar um suporte com perfurações, estas perfurações auxiliam a drenagem do excesso de água da espuma de resina fenólica.

Com as placas de espuma de resina fenólica levemente umedecidas, iniciou-se a semeadura. Foram feitas perfurações com o auxílio de uma pinça de dentista com ponta curva para efetuar o orificio e acomodar a semente. Deve-se ter o cuidado em manter a mesma profundidade nos orifícios. Depositou-se uma semente por orifício, posteriormente cobrindo-a com uma fina camada de espuma fenólica remanescente do orifício (Furlani ${ }^{7}$ ). Através do Anexo D é possível visualizar o procedimento.

Por fim as placas foram depositadas na parte dorsal (base) de bandejas de isopor e irrigadas apenas com água.

A semeadura foi realizada no dia 04/01/2001 e as placas de espuma de resina fenólica foram mantidas em local fresco $\left(20\right.$ a $\left.25^{\circ} \mathrm{C}\right)$ e com luminosidade.

A emergência ocorreu no segundo dia após a semeadura, em 06/01/2001.

As placas de espuma fenólica, quando preciso, foram subirrigadas com solução nutritiva diluída a $50 \%$. A espuma foi mantida sempre úmida, porém evitandose o encharcamento.

${ }^{7}$ FURLANI, P.R. (IAC. Seção Fertilidade do solo, Campinas). Comunicação pessoal, 2000. 


\subsubsection{Transplante intermediário e condução}

As mudas foram transplantadas para o ambiente protegido (berçário) em 18/01/2001, quando a primeira folha verdadeira foi expandida.

Para o transplante, as células da espuma foram destacadas uma a uma e depositadas no orificio do perfil com a ajuda de uma pinça elaborada por uma tira dobrada de cano de PVC, com aproximadamente $1 \mathrm{~cm}$ de largura.

Durante o período que as mudas permaneceram no berçário, a solução nutritiva continuou sendo diluída a 50\%. A renovação da solução nutritiva foi diária em decorrência do alto consumo de solução nutritiva aliada a alta temperatura e ao pequeno volume do tanque de abastecimento $(250 \mathrm{~L})$.

O temporizador foi regulado para permitir a circulação da solução nutritiva por 15 minutos a cada 15 minutos durante o dia (das 7:00 às 21:00 horas) e uma vez a cada hora durante o período noturno.

A vazão média da solução nutritiva foi aproximadamente de 2 L/minuto/perfil.

Vale lembrar que a espuma fenólica é um material inerte e desta forma não disponibiliza nutrientes para as mudas, ao contrário de vários substratos comerciais. Assim, houve sempre necessidade de estar atento a disponibilização de adubo para as plantas.

O método utilizado para a produção de mudas, em conjunto com a qualidade do substrato e adubo, aliado ainda a qualidade das sementes, proporcionou emergência e desenvolvimento bastante uniformes.

No cultivo de melão em ambiente protegido habitualmente as plantas são tutoradas na vertical e podadas, para através do crescimento em altura, melhorar a ocupação da área da estufa (Monteiro \& Mexia, 1988). Assim, optou-se por conduzi-la em haste única, já que Maruyama (1999) comenta que a variação no sólido solúveis provavelmente não advém do sistema de condução (1 ou 2 hastes) e sim da própria cultivar usada. Houve necessidade diária do desbrotamento dos futuros ramos laterais (secundários). 
Aos 20 dias após a semeadura foi introduzido na haste principal da muda um bloco de espuma de colchão, com a finalidade de proteger a haste de possíveis danos devido ao contato constante com o orifício do perfil, além de auxiliar a muda para que permanecesse na posição vertical e não deitada sobre o perfil e sobre outras mudas. $O$ bloco de espuma foi fixado dentro do orifício do perfil e no momento do transplante para o perfil definitivo, o bloco de espuma foi transplantado conjuntamente com a muda.

Deve-se ter o cuidado para que o bloco de espuma não entre em contato com a solução nutritiva, pois, este absorveria a solução nutritiva e, consequentemente, levaria a redução drástica da solução nutritiva circulante.

\subsubsection{Preparo da solução nutritiva}

Através de dados de Pardossi (1994), Furlani et al. (1999), Castellane \& Araujo (1995) e Rincón Sanchez (1997), optou-se por utilizar as concentrações nutritivas recomendadas por Castellane \& Araujo (1995) para a formulação das soluções nutritivas.

Como foram estudadas duas relações $\mathrm{K}: \mathrm{N}$, foram calculadas duas soluções nutritivas, cuja composição dos macronutrientes é verificada nos Quadros $8 \mathrm{e}$ 9.

\begin{tabular}{|l|l|l|l|}
\hline Relação K:N $=1,3: 1$ & Relação K:N $=2,6: 1$ \\
\hline Nutriente & Concentração (ppm) & Nutriente & Concentração (ppm) \\
\hline $\mathrm{N}$ & 170 & $\mathrm{~N}$ & 170 \\
\hline $\mathrm{P}$ & 39 & $\mathrm{P}$ & 39 \\
\hline $\mathrm{K}$ & 225 & $\mathrm{~K}$ & 450 \\
\hline $\mathrm{Ca}$ & 153 & $\mathrm{Ca}$ & 153 \\
\hline $\mathrm{Mg}$ & 24 & $\mathrm{Mg}$ & 24 \\
\hline $\mathrm{S}$ & 32 & $\mathrm{~S}$ & 32 \\
\hline
\end{tabular}

Quadro 8- Concentração de macronutrientes recomendada 


\begin{tabular}{|l|l|l|l|}
\hline Relação $\mathrm{K}: \mathrm{N}=1,3: 1$ & \multicolumn{2}{|l|}{ Relação $\mathrm{K}: \mathrm{N}=2,6: 1$} \\
\hline Adubo utilizado & Solução final $(\mathrm{g} / 1000 \mathrm{~L})$ & Adubo utilizado & Solução final (g/1000L) \\
\hline Nitrato de $\mathrm{Ca}$ & 805,0 & Nitrato de $\mathrm{Ca}$ & 805,0 \\
\hline Nitrato de $\mathrm{K}$ & 334,8 & Nitrato de $\mathrm{K}$ & 334,8 \\
\hline Fosfato de $\mathrm{K}$ & 175,4 & Fosfato de $\mathrm{K}$ & 175,4 \\
\hline Sulfato de $\mathrm{K}$ & 118,6 & Sulfato de $\mathrm{K}$ & 389,7 \\
\hline Sulfato de $\mathrm{Mg}$ & 252,6 & Sulfato de $\mathrm{Mg}$ & 252,6 \\
\hline & & Cloreto de K & 224,1 \\
\hline
\end{tabular}

Quadro 9- Adubo utilizado e solução nutritiva final utilizada

Com relação aos micronutrientes, foi utilizada a mesma concentração para a formulação das duas soluções (relação $K: N$ ), cuja composição é vista no Quadro 10.

\begin{tabular}{|l|l|l|l|}
\hline Nutriente & Concentração $(\mathrm{ppm})$ & Adubo utilizado & Solução final $(\mathrm{g} / 1000 \mathrm{~L})$ \\
\hline $\mathrm{Fe}$ & 2,2 & Fe-EDTA & 36,70 \\
\hline $\mathrm{Mn}$ & 0,6 & Sulfato de $\mathrm{Mn}$ & 2,00 \\
\hline $\mathrm{Zn}$ & 0,3 & Sulfato de $\mathrm{Zn}$ & 1,40 \\
\hline $\mathrm{Cu}$ & 0,03 & Sulfato de $\mathrm{Cu}$ & 0,20 \\
\hline $\mathrm{B}$ & 0,2 & Ácido Bórico & 1,80 \\
\hline $\mathrm{Mo}$ & 0,05 & Molibdato de $\mathrm{Na}$ & 0,12 \\
\hline
\end{tabular}

Quadro 10- Concentração de micronutrientes recomendada, adubo utilizado e solução final utilizada.

Com a finalidade de promover maior facilidade e rapidez na suplementação da solução nutritiva absorvida diariamente, foi preparada soluções estoque para cada macronutriente, uma solução estoque para o Fe-EDTA e por fim uma única solução estoque para todos os micronutrientes, exceto o Fe.

A solução estoque para cada macronutriente foi preparada baseada na solubilidade mais baixa dos macronutrientes utilizadas, ou seja, a do $\mathrm{KCl}$. Desta forma $3 \mathrm{~L}$ de qualquer solução estoque continha a quantidade recomendada do macronutriente para $1.000 \mathrm{~L}$ de solução nutritiva. No momento da reposição ou troca da solução nutritiva, o mesmo volume era utilizado para todos os macronutrientes. 
Foram preparados $24 \mathrm{~L}$ de solução estoque para cada macronutriente, 8 vezes a quantidade recomendada de cada macronutriente para $1.000 \mathrm{~L}$ de solução nutritiva.

Em virtude das pequenas quantidades utilizadas, os micronutrientes, exceto o Fe, foram fornecidos através de uma única solução estoque. A solução estoque foi preparada baseada na solubilidade mais baixa entre os micronutrientes utilizados, ou seja, o ácido bórico. Assim, $1 \mathrm{~L}$ de solução estoque continha a quantidade recomendada de qualquer micronutriente. A mesma relação foi utilizada pelo Fe-EDTA. Então o mesmo volume de solução estoque era utilizado tanto para os micronutrientes, como para o Fe-EDTA.

\subsubsection{Transplante definitivo e condução do experimento}

As plantas foram transplantadas para o perfil definitivo em 31/01/2001. Estas plantas já apresentavam o sistema radicular desenvolvido facilitando na adaptação e absorção da solução nutritiva. A altura das plantas foi suficiente para alcançar e fixarse no fitilho do sistema de condução implantado. Aparentemente não foi visível qualquer tipo de estresse por parte das plantas durante os primeiros dias após o transplante.

Para a condução das plantas no interior do ambiente protegido, utilizou-se o sistema de tutoramento, na qual as plantas são conduzidas verticalmente, envolvidas em fita de nylon. À medida que as plantas se desenvolviam, sua haste foi sendo envolta na fita. Esta prática foi feita diariamente. $\mathrm{O}$ sistema de tutoramento vertical adotado foi o de haste única, fazendo-se o desbaste de todos os brotos laterais até o $10^{\circ}-12^{\circ}$ nó. A partir do $11^{\circ}, 12^{\circ}, 13^{\circ}$ e $14^{\circ}$ nó foram deixados os brotos que deram origem aos ramos secundários. Nestes ramos secundários surgiram as flores que deveriam ser polinizadas para permitir o surgimento dos futuros frutos.

O procedimento realizado nestes 4 ramos secundários foi de retirar todos os brotos que surgiram (ramos terciários) e fazer o desponte do ramo uma folha após o pegamento do fruto. Quanto mais elevada for a área foliar ao dispor de cada fruto, maiores serão o peso médio e o conteúdo de sólido solúveis (Monteiro \& Mexia, 1988). 
Nos próximos entrenós, continuou-se a retirar todos os brotos, isto até a planta atingir o arame de sustentação da fita de nylon. Neste momento foi feita a capação da haste principal.

O ideal é deixar o mesmo número de folhas (entrenós), tanto acima como abaixo dos entrenós onde estão localizados os frutos.

$\mathrm{O}$ raleio dos frutos foi realizado após a constatação do pegamento e desenvolvimento inicial ( $3 \mathrm{~cm}$ de diâmetro) dos mesmos, deixando-se posteriormente apenas dois frutos por planta (Factor, 2000).

Hughes et al. (1983) demonstram que os frutos situados muito próximos uns dos outros competem entre si pelas mesmas folhas. Assim, segundo Monteiro \& Mexia (1988), é freqüente o abortamento da maioria dos frutos recém fixados de modo que pequena parte completa o seu desenvolvimento.

O meloeiro é uma espécie tipicamente de polinização entomológica, necessitando dos insetos (principalmente abelhas) por conter pólen grosso e pesado, que não movimenta com o vento (Sobrino Illescas \& Sobrino Vesperinas, 1989). Desta forma, como o experimento foi desenvolvido em ambiente protegido, a polinização foi feita inicialmente de forma manual, no período da manhã, visando garantir a polinização e o pegamento dos frutos. As flores polinizadas foram identificadas através de etiquetas com a data da polinização. No entanto, devido ao grande número de plantas a serem polinizadas em relação ao pequeno espaço de tempo e período de abertura das flores, foi constatado que não seria possível a polinização manual de um número adequado de flores para garantir que todas as plantas obtivessem pelo menos dois frutos.

Instalou-se então, uma colmeia de abelhas européias no dia 18/02/2001, garantindo desta forma, a eficaz polinização de todas as plantas.

A desfolha das folhas em senescência foi realizada no dia 03/03/2001, ou seja, 58 dias após a semeadura, esta operação favorece a ventilação, auxilia no controle da temperatura e evitando problemas de doenças.

Algumas variedades de melão quando maduros desprendem-se do pedúnculo devido ao anel de abscisão formado (Menezes, 1996), sendo necessário a fixação do fruto, evitando sua queda. Para os dois híbridos utilizados no experimento, 
não houve a necessidade de fixação dos frutos, já que os frutos permaneceram aderidos ao pedúnculo até o momento da colheita.

O controle fitossanitário foi realizado de forma preventiva, utilizando-se a dose indicada para o cultivo de melão em campo aberto. Foram realizadas duas pulverizações, a primeira no dia 15/02/2001, com os produtos comerciais Folpan Agricur 500PM e Applaud (dose para tomate) e a segunda no dia 08/03/2001 com os produtos comerciais Benlate 500 e Decis $25 \mathrm{CE}$.

Para evitar mudanças indesejáveis na concentração da solução nutritiva, o monitoramento das soluções nutritivas, foi realizado da seguinte maneira: diariamente era completado o volume do tanque da solução nutritiva com água e medida a EC. A reposição da solução nutritiva era feita através da EC, ou seja, foi estabelecida a EC inicial para a solução completa (100\% da concentração recomendada) e através da porcentagem advinda da queda da condutividade obtinha-se a porcentagem de nutrientes que deveriam ser adicionados ao tanque de solução nutritiva para atingir novamente a EC inicial.

Como foi utilizado soluções estoque para os nutrientes, em particular para os macronutrientes era sabido que $3 \mathrm{~L}$ de qualquer solução estoque continha $100 \%$ da concentração indicada para a solução completa, então, através de regra de três obtinha-se a quantidade em litros da solução estoque que correspondia a porcentagem de queda da EC inicial.

O mesmo procedimento foi realizado para os micronutrientes e para o $\mathrm{Fe}$ EDTA, porém utilizando 1 litro como contendo $100 \%$ da concentração indicada para a solução completa inicial.

A solução nutritiva foi trocada em torno de 3-4 semanas.

$\mathrm{O} \mathrm{pH}$ foi corrigido diariamente para ficar na faixa de 6-6,5. Diariamente, após a complementação dos tanques de solução com água limpa e reposição dos nutrientes, o pH era medido com peagâmetro portátil e se a solução estivesse ácida ( $\mathrm{pH}$ abaixo de 6) era corrigida com adição de hidróxido de potássio, ou caso a solução estivesse básica ( $\mathrm{pH}$ acima de 6,5) era corrigida com adição de ácido nítrico. 


\subsubsection{Aplicação dos tratamentos}

Cada solução foi aplicada através de sistema independente, composto por um tanque de solução nutritiva (capacidade de $1.500 \mathrm{~L}$ ), perfis recipientes, tubulações de abastecimento e de retorno ao tanque de solução nutritiva. Para que o sistema de solução recirculante pudesse funcionar, foi necessário acoplar a cada linha um conjunto motobomba.

O temporizador foi regulado para permanecer circulando solução durante 10 minutos e permanecer desligado durante 20 minutos, a partir do dia 08/03/2001 optou-se por interromper as irrigações no período noturno (após às 22:00 horas) e tornar a ligar o temporizador a partir das 7:30 horas da manhã.

A partir do dia 28/02/2001, após 56 dias da semeadura, já havia terminado a polinização e a relação $\mathrm{K}: \mathrm{N}=2,6: 1$ começou a ser aplicada, permanecendo até o final da colheita.

\subsubsection{Colheita}

O híbrido Galileo começou a ser colhido no momento que $60 \%$ do fruto apresentava coloração amarela, iniciando a colheita no dia 1 de abril de 2001 estendendo-se até o dia 12 de abril de 2001.

Para o híbrido Orange Flesh foi realizada uma colheita única no dia 12 de abril de 2001, devido a dificuldade em determinar o ponto ideal de colheita. Melões tipo Honey Dew não apresentam um índice visível de maturidade, semelhante ao desenvolvimento da zona de abscisão ou mudança na cor do exocarpo (Webster, $1975 \mathrm{e}$ Lester \& Shellie, 1992). Naquela data, 93\% dos frutos apresentavam coloração esbranquiçada e os frutos permaneceram aderidos ao pedúnculo. 


\subsection{Avaliação do experimento}

Durante as fases de desenvolvimento do cultivo, foram avaliados o estado nutricional e parâmetros físicos e químico dos frutos do meloeiro.

\subsubsection{Estado nutricional das plantas}

O estado nutricional das plantas foi avaliado através de análise foliar e análise química da solução nutritiva.

A coleta das folhas para análise foliar foi realizada em 17/02/2001, período que a planta já havia atingido o arame superior e florescimento. $\mathrm{Na}$ haste principal, a quinta folha a partir do tufo apical, desprezando-o, foi coletada como amostra para a análise (Raij et al., 1997). Posteriormente, as amostras foram enviadas para o Departamento de Solos e Nutrição de Plantas, ESALQ/USP, para as determinações de macronutrientes $(\mathrm{N}, \mathrm{P}, \mathrm{K}, \mathrm{Ca}, \mathrm{Mg}$ e $\mathrm{S})$ e micronutrientes $(\mathrm{B}, \mathrm{Cu}, \mathrm{Fe}$, $\mathrm{Mn}$, Mo e Zn).

As coletas das amostras para a análise química da solução nutritiva foram realizadas a cada semana a partir da troca da solução nutritiva realizada em 04/03/2001, perfazendo um conjunto de três amostras por tanque de solução nutritiva. Após o volume da solução nutritiva ter sido completado com água e sofrido adição da quantidade de nutrientes supostamente consumidos, coletou-se cerca de $200 \mathrm{ml}$ da solução nutritiva em garrafa plástica de água mineral, a qual foi descartada e a garrafa foi posteriormente armazenada em refrigerador comum até as três amostras terem sido coletadas, e só então, foram enviadas ao UNITHAL, onde foi realizada as análises. Foram determinados macronutrientes $(\mathrm{P}, \mathrm{K}, \mathrm{Ca}, \mathrm{Mg}$ e $\mathrm{S})$, micronutrientes $(\mathrm{B}, \mathrm{Cu}, \mathrm{Fe}$, $\mathrm{Mn}, \mathrm{Mo}, \mathrm{Zn}$ e Na), pH e CE. 


\subsubsection{Parâmetros físicos}

As avaliações foram feitas durante o início do período de colheita estendo-se até 5 dias após o término da colheita.

Os frutos colhidos com pedúnculo com cerca de $2 \mathrm{~cm}$, foram mantidos em câmara fria a $7^{\circ} \mathrm{C}$, para as análises.

As avaliações foram obtidas da amostragem de 40 frutos (20 frutos de cada híbrido) por repetição.

- 3.4.2.1 O peso médio do fruto (PF) foi obtido por pesagem de 20 frutos de cada repetição, utilizando-se balança digital Ohaus modelo Precision Plus, calculando-se a média entre cada repetição.

- 3.4.2.2 O comprimento médio (CF), diâmetro médio (DF), comprimento médio da cavidade (CC), diâmetro médio da cavidade (DC), espessura média distal (ED) e a espessura média da polpa (EP) na região mais equatorial do fruto, foram obtidas dos mesmos frutos do item 3.4.2.1 e medidos através de paquímetro comum, calculando-se a média em cada repetição.

• 3.4.2.3 A relação de formato médio do fruto $(R F)$, foi obtida da relação comprimento/diâmetro (Miccoles \& Saltveit Junior, 1991), verificados no item 3.4.2.2, calculando-se a média em cada repetição.

•3.4.2.4 A determinação da firmeza média da polpa (FIR), representada pela resistência à penetração, usou-se penetrômetro manual Wagner, modelo FDN 20 (capacidade de leitura até $20 \mathrm{~N}$ ), com pluger de ponta redonda (diâmetro $8 \mathrm{~mm}$ ). Os mesmos frutos do item 3.4.2.1 foram avaliados sobre o oposto do lado, ao longo da região equatorial, sem remoção do exocarpo, conforme (Aharoni et al., 1993). Foram realizadas 6 leituras de firmeza por fruto (Miccoles \& Saltveit Junior, 1991). Obtida a firmeza média por fruto, calculou-se a firmeza média por repetição. 


\subsubsection{Parâmetro químico}

O conteúdo médio de sólidos solưveis (SS) foi obtido através de leitura obtida em \%, por meio de refratômetro digital Atago, modelo dbx-30, com capacidade de leitura 0 a $30 \%$ e compensação de temperatura automática, espremendo-se uma pequena porção $(3 \times 3 \mathrm{~cm})$ de polpa à $5 \mathrm{~mm}$ da cavidade central na região equatorial, tomando-se 2 gotas (Bleinroth, 1994) dos mesmos frutos do item 3.4.2.1. Foram realizadas 2 leituras por fruto, uma em cada lado da cavidade central. Obtido o conteúdo de SS médio por fruto, calculou-se o conteúdo médio de SS por repetição. 


\section{RESULTADOS E DISCUSSÃO}

\subsection{Estado nutricional das plantas}

Os resultados obtidos, provenientes da análise foliar e da análise química da solução nutritiva, encontram-se nos Anexos B e C.

De acordo com a análise foliar, fica evidente que a solução nutritiva com relação $\mathrm{K}: \mathrm{N}$ 1,3:1 utilizada até o momento da amostragem, foi adequada para a fase vegetativa em ambos os híbridos.

A análise química da solução nutritiva, permite verificar que não houve grandes desequilibrios na quantidade de macronutrientes e micronutriente presentes nas soluções nutritivas, não houve deficiência nutricional em ambos os híbridos. Além disso, o pH e a EC também permaneceram dentro da faixa considerada adequada.

\subsection{Parâmetros físicos e químico}

Os parâmetros avaliados foram submetidos ao teste $\mathrm{F}$ da análise de variância para identificar as diferenças entre as soluções nutritivas através do suftware SAS (1992). Posteriormente foi usado o teste Tuckey na comparação das médias.

As Tabelas 1 e 2 mostram os resultados do teste $F$, aplicado à análise de variância para os parâmetros avaliados nos híbridos Orange Flesh e Galileo.

As Tabelas 3 e 4 mostram as médias e os resultados do teste de Tukey, para estudo das comparações entre as duas soluções nutritivas, para cada parâmetro avaliado em ambos híbridos. 
De acordo com a Tabela 1 é observado que todos os parâmetros avaliados apresentaram significância para o híbrido Orange Flesh, exceto CC. Por outro lado todos os parâmetros não foram significativos para o Galileo.

Na Tabela 2 apenas os parâmetros EP e SS foram significativos para o Orange Flesh, enquanto que para o Galileo somente EP foi significativo.

Tabela 1. Análise de variância para as características: peso médio do fruto (PF), comprimento médio do fruto $(\mathrm{CF})$, diâmetro médio do fruto (DF), comprimento médio da cavidade (CC) e diâmetro médio da cavidade (DC). ESALQ-USP, Piracicaba-SP, 2001.

\section{Quadrados Médios}

Causas de variação G.L.

PF

CF DF

$\mathrm{CC}$

DC

\section{Orange Flesh}

Bloco

Solução

Resíduo

Total

C.V.\%

Bloco

Solução

Resíduo

Total

C.V.\%

9

$170014,68^{* *}$

1,6416 *

0,1673

19

95043,00

6,30

2,76

Galileo

9

$17607,67^{\text {ns }}$

$0,0436^{\text {ns }}$

0,1029

$0,2822^{\text {ns }}$

$0,0084^{\mathrm{ns}}$

$0,0130^{\mathrm{ns}}$

$4 \quad 1573,19$

14

* Significativo ao nível de $5 \%$ de probabilidade

** Significativo ao nível de $1 \%$ de probabilidade

${ }^{\text {ns }}$ Não significativo 
Tabela 2. Análise de variância para as características: relação média de formato (RF), espessura média distal (ED), espessura média da polpa (EP), conteúdo médio de sólido solúveis (SS) e firmeza média da polpa (FIR). ESALQ-USP, Piracicaba-SP, 2001.

\begin{tabular}{|c|c|c|c|c|c|c|}
\hline \multirow[b]{2}{*}{ Causas de variação } & \multirow[b]{2}{*}{ G.L. } & \multicolumn{5}{|c|}{ Quadrados Médios } \\
\hline & & $\mathrm{RF}$ & $\mathrm{ED}$ & EP & SS & FIR \\
\hline \multicolumn{7}{|c|}{ Orange Flesh } \\
\hline Bloco & 9 & & & & & \\
\hline Solução & 1 & $0,0005^{\mathrm{ns}}$ & $0,0781^{\text {ns }}$ & $0,2599 *$ & $2,6521 * *$ & $0,0007^{\mathrm{ns}}$ \\
\hline Resíduo & 9 & 0,0010 & 0,0345 & 0,0322 & 0,1860 & 3,5128 \\
\hline Total & 19 & & & & & \\
\hline C.V.\% & & 2,60 & $\begin{array}{c}6,89 \\
\text { Galileo }\end{array}$ & 5,32 & 3,75 & 11,97 \\
\hline Bloco & 9 & & & & & \\
\hline Solução & 1 & $0,008^{\mathrm{ns}}$ & $0,0397^{\mathrm{ns}}$ & $0,2592 * *$ & $0,1092^{\mathrm{ns}}$ & $5,1266^{\mathrm{ns}}$ \\
\hline Resíduo & 4 & 0,0028 & 0,0098 & 0,0106 & 0,1783 & 0,6877 \\
\hline Total & 14 & & & & & \\
\hline C.V.\% & & 1,66 & 3,62 & 2,88 & 3,77 & 12,88 \\
\hline
\end{tabular}

\subsubsection{Peso dos frutos}

Neste trabalho, o efeito das diferentes soluções (relação $\mathrm{K}: \mathrm{N}$ ) interferiu no peso médio dos frutos. Verifica-se, por intermédio da Tabela 1, que houve diferença significativa entre as soluções 1 e 2 para o híbrido Orange Flesh ao nível de $1 \%$ de probabilidade, no entanto, pode-se verificar que não houve diferença significativa em relação ao híbrido Galileo.

Knavel (1988) considera que o peso dos frutos está intimamente relacionado às características próprias de crescimento de cada cultivar, sendo que Martins et al. (1998) acham que dentro das faixas de boa nutrição mineral e disponibilidade de água o tamanho, e consequentemente, o peso do fruto dependem mais da cultivar do que de outros fatores. 
Os resultados obtidos concordam com Martins et al. (1998), pois, para o híbrido Orange Flesh, a solução 2 apresentou-se mais adequada em relação ao ganho de peso médio do fruto.

Nota-se pela análise da Tabela 3, que o híbrido Orange Flesh obteve maior peso médio do fruto na solução 2 do que na solução 1 (1186,70 e 1068,36g, respectivamente). Havendo acréscimo aproximadamente de $10 \%$ no peso médio do fruto em relação a solução 1 .

Estes dados concordam com Pinto et al. (1996a), Prabhakar at al. (1985), Economakis et al. (2001) e Khosla \& Papadopoulos (2001).

Segundo Pinto et al. (1996a), em experimento em condições de solo com doses de $\mathrm{K}\left(0,45,90\right.$ e $135 \mathrm{~kg} / \mathrm{ha}$ de $\left.\mathrm{K}_{2} \mathrm{O}\right)$, aplicados via fertirrigação na cultura do melão, houve efeito positivo na produtividade, causado pelo aumento do peso dos frutos devido a adição de $\mathrm{K}$.

Prabhakar at al. (1985), estudando durante cinco anos (1979 a 1985), a qualidade de melões em relação ao espaçamento e fertilização, observaram que a aplicação de $\mathrm{K}$ elevou em $12 \%$ o peso dos frutos de melão, principalmente devido ao seu papel na translocação de carboidratos para os frutos.

Economakis et al. (2001), avaliando três concentrações de K (200, 290 e $340 \mathrm{ppm})$ em solução nutritiva, apresentando as seguintes relações $\mathrm{K}: \mathrm{N}(1.2: 1 ; 1,7: 1 \mathrm{e}$ 2:1) respectivamente, no cultivo de tomate (Lycopersicon esculentum Mill.) em bags preenchidos com pumice, constataram que o peso médio de frutos (acima de 150g) aumentou com o incremento de $\mathrm{K}$ na solução nutritiva quando utilizando substrato novo.

Khosla \& Papadopoulos (2001), trabalhando com tomate cultivado em lãde-rocha embebida em solução nutritiva contendo quatro relações $\mathrm{K}: \mathrm{N}(1: 1,2: 1$, 4:1 e 6:1), observaram que, conforme esta relação aumentou até $4: 1$, houve significativo aumento no tamanho dos frutos comerciais, porém, a maior relação foi estatisticamente igual a relação 1:1 quando utilizou-se EC igual a $3000 \mu \mathrm{m} / \mathrm{cm}$. 
Tabela 3. Médias observadas nos híbridos Orange Flesh e Galileo para os parâmetros: peso médio do fruto $(\mathrm{PF})$, comprimento médio do fruto $(\mathrm{CF})$, diâmetro médio do fruto (DF), comprimento médio da cavidade (CC) e diâmetro médio da cavidade (DC). ESALQ-USP, Piracicaba-SP, 2001.

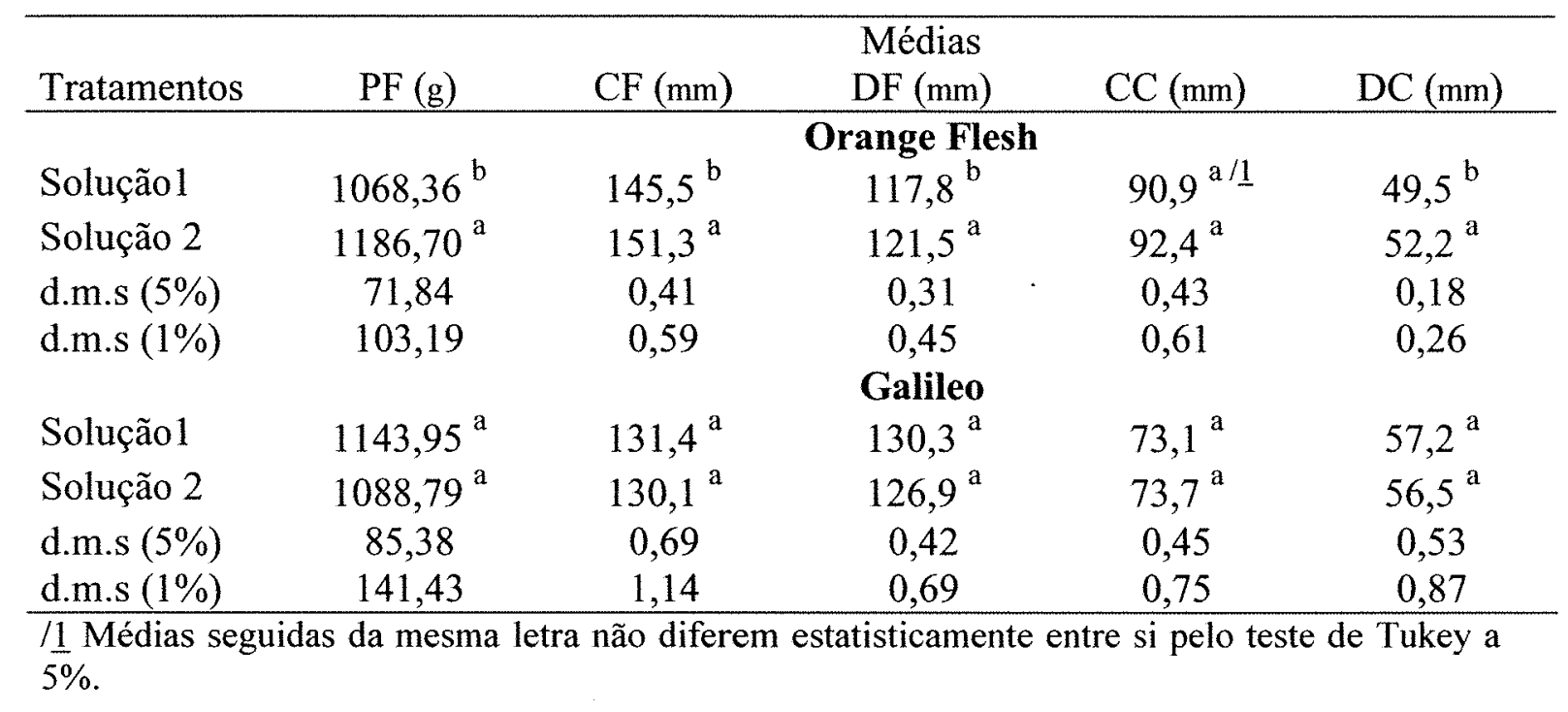

Por outro lado, para o híbrido Galileo não houve efeito significativo com relação ao peso médio de frutos, mas foi notada uma tendência de perda de peso médio do fruto da ordem de 4,8\% (1143,95 para $1088,79 \mathrm{~g})$ com o aumento da relação $\mathrm{K}: \mathrm{N}$. Estes dados concordam com Mortley et al.(1993), Pardossi et al. (1995), Feitosa Filho et al. (2001b) e Pontes (2001).

Pardossi et al. (1995) realizaram ensaio em NFT com melão avaliando oito soluções nutritivas com as seguintes relações $\mathrm{K}: \mathrm{N}(1,7: 1 ; 3,4: 1 ; 2,62: 1 ; 3,08: 1$ e 2,25:1), durante a primavera e verão de 1992 e 1993. Concluíram que a produtividade não foi influenciada pela composição da solução nutritiva.

Mortley et al. (1993), em estudo para determinar a relação K:N ótima para o cultivo em NFT da batata-doce (Ipomoea batatas L.) sob condições de ambiente controlado, utilizaram as relações $K: N$ 1,1:1; 2,4:1 e 3,6:1 e não verificaram diferença estatística no peso fresco da batata-doce entre as relações $\mathrm{K}: \mathrm{N}$ testadas em ambas cultivares utilizadas. 
Feitosa Filho et al. (2001b), cultivando banana com o objetivo de avaliar o efeito da redução de 25 e $50 \%$ das doses de $\mathrm{N}$ e $\mathrm{K}$ aplicadas via fertirrigação em relação às recomendadas para a adubação convencional, constataram que a redução em até $50 \%$ da dose de $\mathrm{K}$ não interferiu estatisticamente no peso médio dos frutos, das pencas e cachos de banana.

Pontes (2001), trabalhando com tomate em NFT, observou que houve uma queda do peso médio de frutos por planta quando comparando a relação $\mathrm{K}: \mathrm{N} 2: 1$ com 3:1 e 2:1 até o início do florescimento e 3:1 no restante do ciclo.

Os dados observados para o híbrido Galileo, por sua vez, concordam com Sousa (2000) e Costa (1999) a respeito do efeito não significativo em relação ao peso médio de frutos, mas por outro lado, discordam quando sugerem uma tendência ao ganho de peso médio do fruto com a elevação da dose de $\mathrm{K}$.

Costa (1999), trabalhando com tomate em vasos contendo vermiculita e recebendo solução nutritiva por inundação através de sistema fechado de circulação, observou que não houve diferença significativa entre as doses de $K$ testadas, porém observou que a maior dose de $\mathrm{K}$ levou a um aumento no peso de frutos da ordem de $10,1 \%$

Esta tendência a perda de peso na solução 2 pode ser decorrente do ataque por Fusarium oxysporum f. sp. melonis, identificado pela Clínica de Fitopatologia da ESALQ/USP. O híbrido Galileo apresentou-se mais suscetível do que o Orange Flesh ao ataque, havendo perda de algumas plantas. Provavelmente para o híbrido Galileo na solução 2, o Fusarium foi um oportunista, talvez decorrente do estresse devido ao aumento da EC da solução 2, ou das quantidades e constituintes desta solução.

A Figura 2 representa graficamente o peso médio dos frutos, para as relações 1,3:1 e 2,6:1, para cada híbrido analisado. Através da análise da Figura 2, verifica-se a diferença existente entre as soluções 1 e 2 para o híbrido Orange Flesh em relação ao peso médio de frutos e a tendência a perda de ganho de peso para o híbrido Galileo na solução 2 .

O peso médio do híbrido Orange Flesh encontrado na colheita para a relação $\mathrm{K}: \mathrm{N}$ 1,3:1 e 2,6:1 foi de 1068,36 e 1186,70g, para a solução 1 foi ligeiramente 
abaixo do observado por Fernandes (1996), enquanto para a solução 2 foi bem semelhante, cujo peso médio dos frutos do híbrido Orange Flesh obtido da caracterização dos frutos foi $1186 \mathrm{~g}$.

\section{Peso médio dos frutos}

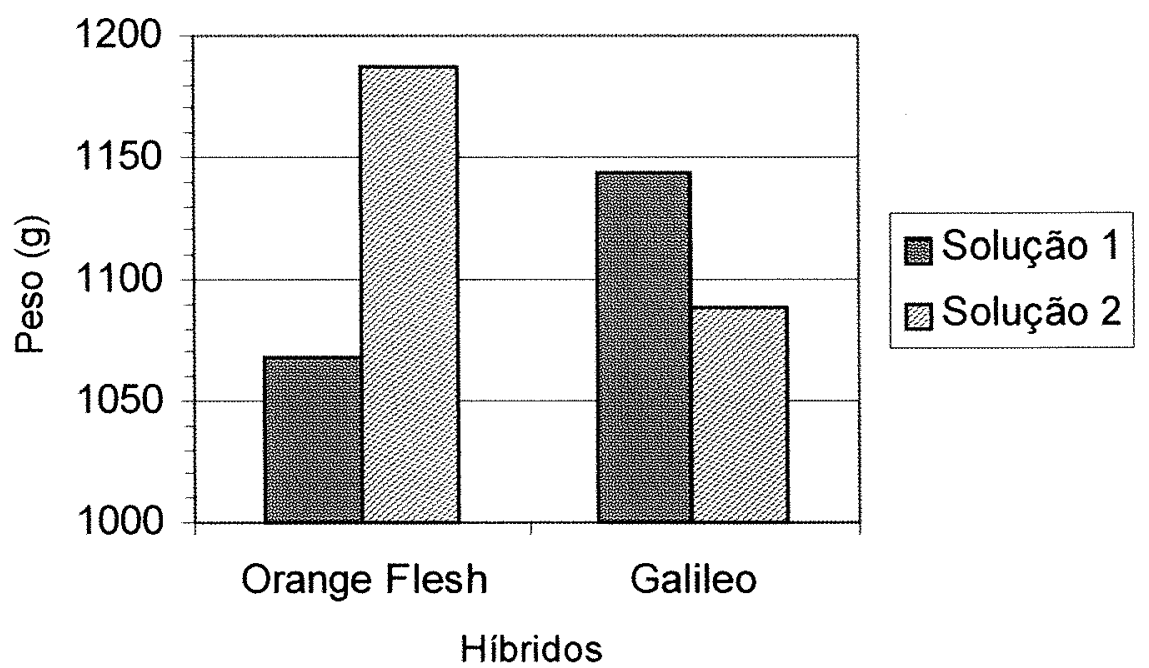

Figura 2- Peso médio de frutos, nas soluções 1 e 2, para os híbridos Orange Flesh e Galileo, ESALQ-USP, Piracicaba-SP, 2001.

Para o híbrido Galileo, o peso médio na colheita para as relações K:N 1,3:1 e 2,6:1 foi de 1143,95 e 1088,79g. De acordo com Zapata et al. (1989) e Torres et al. (1997), o melão tipo Galia pesa em média 850 a $1900 \mathrm{~g}$ e 700 a $1300 \mathrm{~g}$, respectivamente. Os valores encontrados estão, portanto, dentro da faixa considerada ideal para este tipo de melão.

Estes resultados são semelhantes aos reportados por Mendlinger (1994) em estudo sobre a qualidade do melão Galia, o qual verificou peso médio dos frutos controle de $1016 \mathrm{~g}$ e Martins et al. (1998) que obtiveram frutos com $1220 \mathrm{~g}$ de peso médio para a cultivar Melina, melão tipo Galia. No entanto, é muito inferior aquele 
reportado por Cocozza (1997) e Menezes (1996), cujos pesos médio encontrado na colheita foram 1688,23 e 1351,20g, respectivamente. Por outro lado, é superior ao obtido por Artés et al. (1993) e Franco et al. (1993) para o melão cultivado na região de Múrcia, Espanha, que foi 930 e $690 \mathrm{~g}$, respectivamente.

\subsubsection{Comprimento e diâmetro dos frutos}

Na Tabela 1 é visto que houve diferença significativa ao nível de $5 \%$ de probabilidade entre ambas relações K:N utilizadas para o híbrido Orange Flesh, sendo que a relação 2,6:1 apresentou frutos com maior comprimento médio (Tabela 3). Para o híbrido Galileo o comprimento médio dos frutos não diferiu estatisticamente entre as soluções utilizadas.

Da mesma forma que o comprimento médio, para o híbrido Orange Flesh o diâmetro médio apresentou diferença significativa ao nível de $5 \%$ de probabilidade entre as relações K:N (Tabela 1), onde foi verificado que a relação 2,6:1 proporcionou frutos com maior diâmetro médio (Tabela 3). O mesmo não ocorreu com o híbrido Galileo, onde o diâmetro médio não diferiu estatisticamente entre ambas relações $\mathrm{K}: \mathrm{N}$.

Soares (2001), em condições de solo, não obteve diferença significativa nos parâmetros diâmetro e comprimento de frutos do meloeiro, quando utilizou diferentes doses de $\mathrm{K}(30,90,150$ e $210 \mathrm{~kg} / \mathrm{ha})$ aplicadas via fertirrigação, no cultivo de melão.

Feitosa Filho et al. (2001a), estudando diferentes doses de $\mathrm{N}$ e K aplicadas por fertirrigação, verificaram que a redução ou aumento nas doses de $\mathrm{K}$ não influenciaram o diâmetro médio e comprimento dos frutos de pimentão (Capsicum annum L.) cultivado no solo.

Costa (1999), trabalhando com tomate em vasos contendo vermiculita recebendo solução nutritiva por inundação, verificou que o diâmetro dos frutos de tomate não diferiu estatisticamente em ambas doses de $\mathrm{K}$ utilizadas, embora a utilização da maior dose de $\mathrm{K}$ tenha produzido frutos com diâmetro médio 3,8\% maiores do que o diâmetro médio dos frutos na menor dose. 
Pontes (2001), trabalhando com diferentes relações K:N em NFT, observou pequena diminuição no diâmetro médio de tomate/planta quando comparou a relação K:N 2:1 com 3:1 e 2:1 até o início do florescimento e 3:1 no restante do ciclo.

Para os híbridos Orange Flesh e Galileo, através da Figura 3, é possível verificar graficamente o comprimento médio dos frutos, para as soluções 1 e 2 .

\section{Comprimento médio dos frutos}

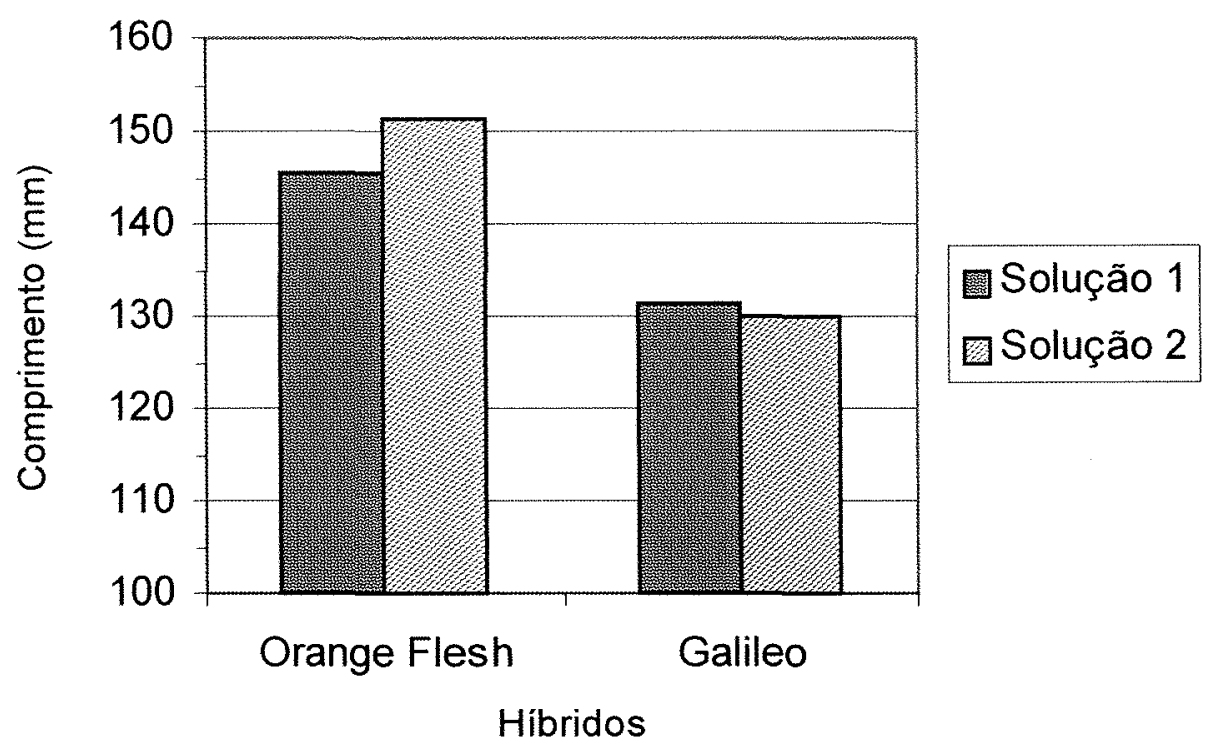

Figura 3- Comprimento médio de frutos, nas soluções 1 e 2, para os híbridos Orange Flesh e Galileo, ESALQ-USP, Piracicaba-SP, 2001.

O comprimento médio do híbrido Orange Flesh obtido na colheita para as relações K:N 1,3:1 e 2,6:1 foi de 145,50 e 151,30mm, bem superiores ao comprimento observado por Fernandes (1996) durante a caracterização do melão Orange Flesh, cujo comprimento foi $138 \mathrm{~mm}$.

Para o híbrido Galileo, o comprimento médio na colheita para as relações $\mathrm{K}: \mathrm{N}$ 1,3:1 e 2,6:1 foi de 131,40 e $130,10 \mathrm{~mm}$, respectivamente, são ligeiramente 
inferiores aos reportados por Cocozza (1997) que obteve para os frutos controle de seu experimento à campo comprimento médio de $137,40 \mathrm{~mm}$. Mas, são muito superiores ao reportado por Artés et al. (1993), cujo comprimento médio foi $105 \mathrm{~mm}$. Todavia, os valores obtidos neste trabalho estão dentro da faixa considerada ideal para o melão tipo Galia que é ao redor de 130mm (Zapata et al., 1989).

Em relação ao diâmetro médio dos frutos, a Figura 4 representa graficamente o diâmetro médio dos frutos, para as relações 1,3:1 e 2,6:1, para cada híbrido analisado.

\section{Diâmetro médio dos frutos}

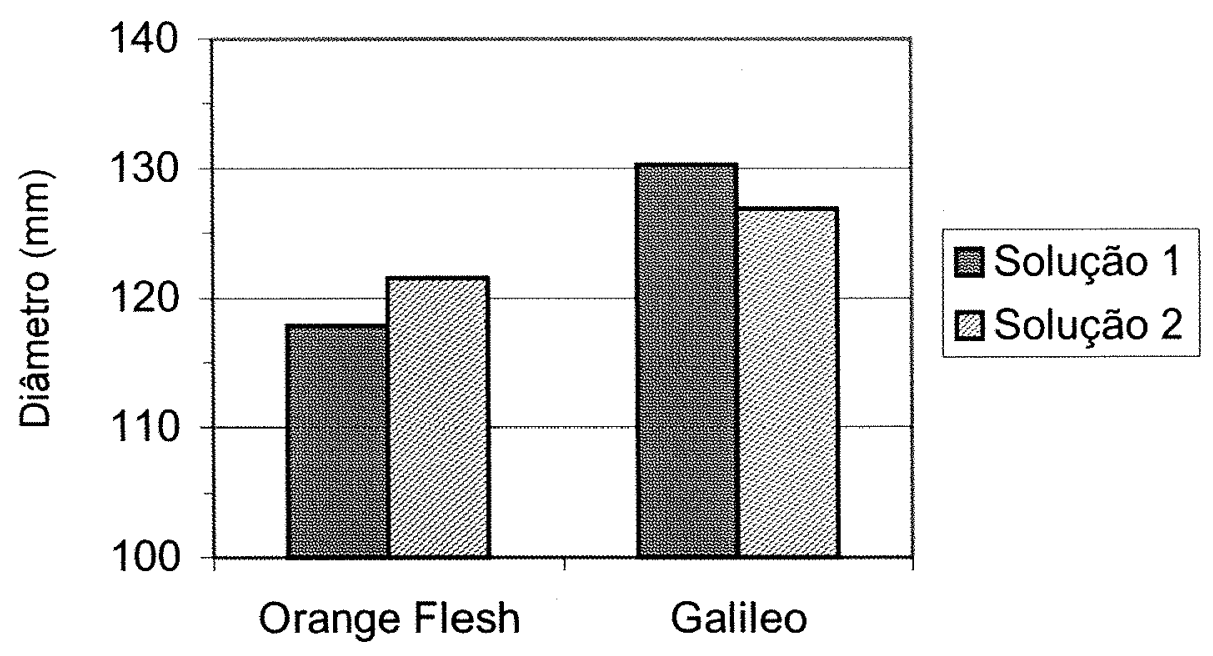

Híbridos

Figura 4- Diâmetro médio de frutos, nas soluções 1 e 2, para os híbridos Orange Flesh e Galileo, ESALQ-USP, Piracicaba-SP, 2001.

O diâmetro médio do híbrido Orange Flesh na colheita para as relações $\mathrm{K}: \mathrm{N}$ 1,3:1 e 2,6:1 foi de 117,80 e 121,50mm, apresentando certa similaridade ao obtido por Fernandes (1996) que foi $126,20 \mathrm{~mm}$. 
Para o híbrido Galileo, o diâmetro médio obtido para as soluções 1 e 2 foi de 130,30 e $126,90 \mathrm{~mm}$, respectivamente, sendo inferiores aos reportados por Menezes (1996) e Cocozza (1997) que obtiveram frutos com diâmetro médio de 133 e 139,56mm, respectivamente. Porém, são superiores ao obtido por Artés et al. (1993), que verificou diâmetro médio de $114 \mathrm{~mm}$. Contudo, os valores encontrados neste trabalho estão muito próximos do considerado ideal por Zapata et al. (1989), com diâmetro aproximadamente de $134 \mathrm{~mm}$.

\subsubsection{Comprimento e diâmetro da cavidade}

As diferentes soluções (relação $\mathrm{K}: \mathrm{N}$ ) não influenciaram no comprimento médio da cavidade dos frutos. Verifica-se por intermédio da Tabela 1 que não houve efeito estatístico entre as soluções 1 e 2 , para ambos híbridos analisados.

A Tabela 3 mostra que, de modo geral os híbridos comportaram-se de maneira semelhante entre as soluções 1 e 2 , ou seja, cada híbrido apresentou comprimento médio da cavidade semelhante tanto na solução 1 como na 2.

Para o híbrido Orange Flesh e Galileo através da Figura 5, é possível verificar graficamente o comprimento médio da cavidade, para as relações $K: N$ 1,3:1 e $2,6: 1$.

O comprimento médio da cavidade do híbrido Orange Flesh encontrado na colheita para as soluções 1 e $2(90,9$ e 92,4mm, respectivamente) foi bem superiores ao reportado por Fernandes (1996) para o mesmo híbrido, cuja caracterização do fruto, obteve melões com $78,6 \mathrm{~mm}$ de comprimento médio da cavidade. 


\section{Comprimento médio da cavidade dos} frutos

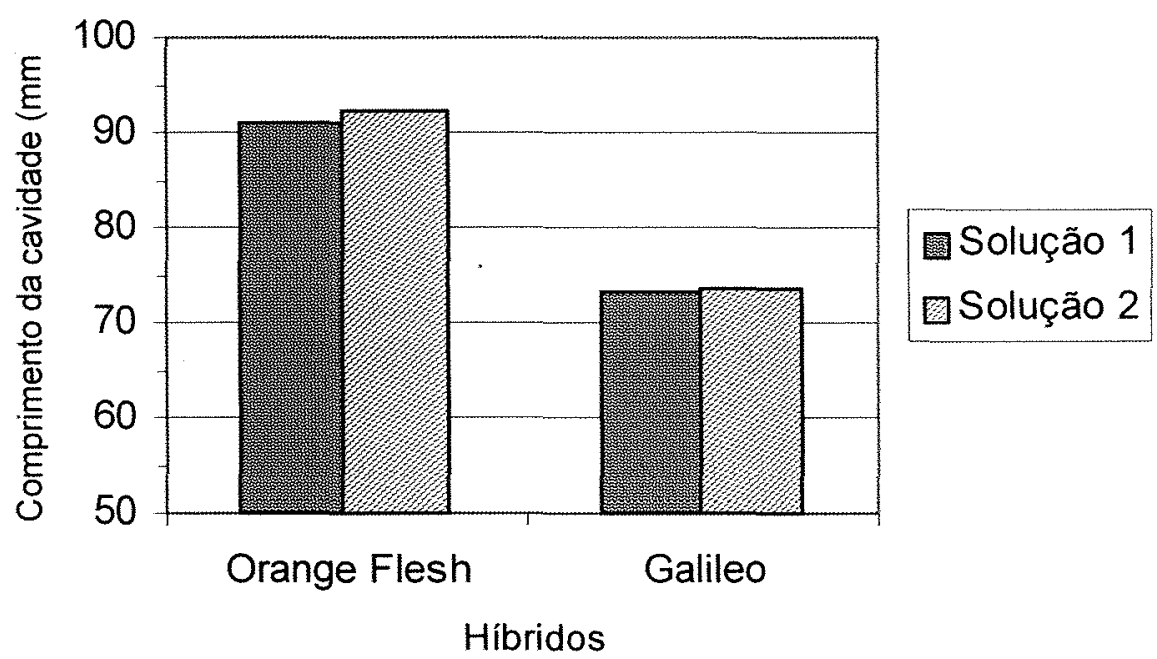

Figura 5- Comprimento médio da cavidade, nas soluções 1 e 2, para os híbridos Orange Flesh e Galileo, ESALQ-USP, Piracicaba-SP, 2001.

$\mathrm{O}$ efeito das diferentes soluções (relação $\mathrm{K}: \mathrm{N}$ ) influenciou no diâmetro médio da cavidade dos frutos. Verifica-se por intermédio da Tabela 1 que houve diferença significativa entre as soluções 1 e 2 para o híbrido Orange Flesh ao nível de $1 \%$ de probabilidade, no entanto, pode-se verificar ainda, que não houve efeito estatístico em relação ao híbrido Galileo.

Nota-se pela análise da Tabela 3 que o híbrido Orange Flesh obteve maior diâmetro médio da cavidade na relação $2,6: 1$ do que na relação $1,3: 1$ (52,2 e 49,5mm, respectivamente). Havendo incremento de aproximadamente $5,2 \%$ no diâmetro médio da cavidade na solução 2 em relação a solução 1 .

A Figura 6 representa graficamente o diâmetro médio da cavidade dos frutos, para as soluções 1 e 2 , para cada híbrido analisado. 
O diâmetro médio da cavidade do híbrido Orange Flesh encontrado na colheita para as soluções 1 e $2(49,5$ e $52,2 \mathrm{~mm}$, respectivamente) foi inferior ao reportado por Fernandes (1996) para o mesmo híbrido, cuja caracterização do fruto obteve melões com $55,6 \mathrm{~mm}$ de diâmetro da cavidade.

Para o híbrido Galileo, o diâmetro médio da cavidade na colheita para as soluções 1 e 2 (73,1 e 73,7mm, respectivamente) foi bem superiores ao obtido por Menezes (1996), para o melão tipo Galia cultivado à campo, cujo valor foi 50,4mm.

\section{Diâmetro médio da cavidade dos frutos}

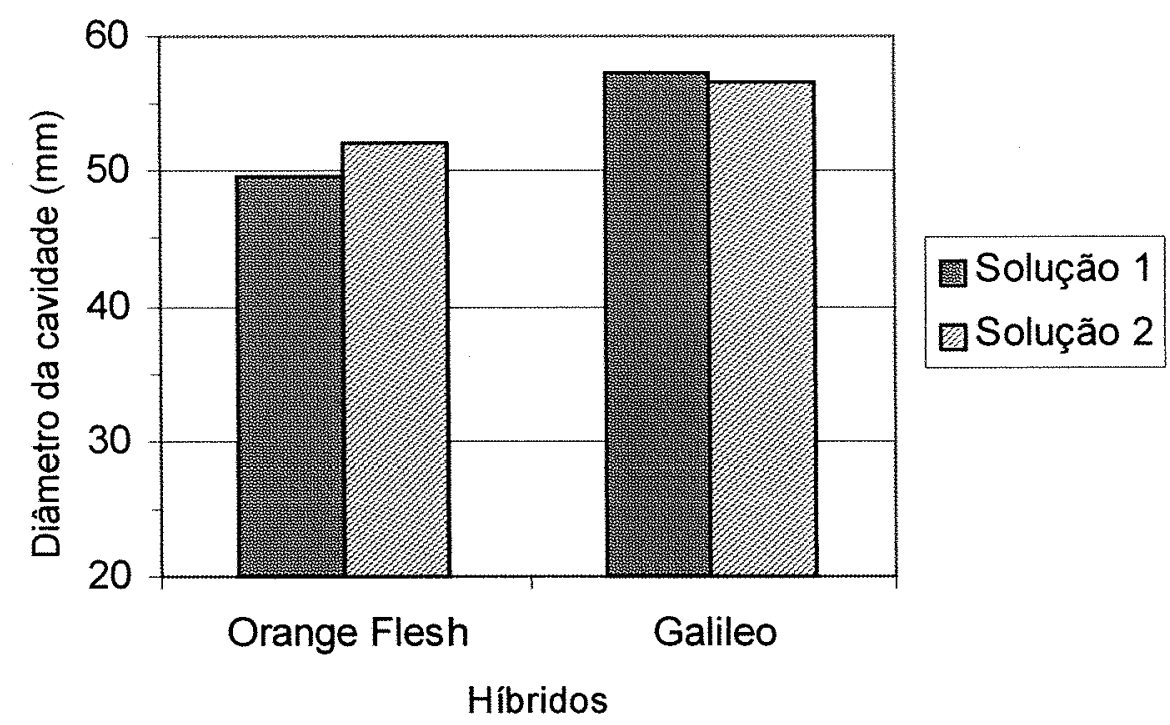

Figura 6- Diâmetro médio da cavidade, nas soluções 1 e 2, para os híbridos Orange Flesh e Galileo, ESALQ-USP, Piracicaba-SP, 2001. 


\subsubsection{Relação de formato do fruto (RF)}

Tanto o comprimento quanto $o$ diâmetro dos frutos são parâmetros fundamentais na classificação dos mesmos no mercado e principalmente para o acondicionamento em embalagens padronizadas.

A classificação do formato de frutos de melão é feita tomando-se como base a relação comprimento/diâmetro (Lopes, 1982).

De acordo com a classificação de Lopes (1982), se a referida relação $\mathrm{RF}<1,0$ os frutos são considerados esféricos, de $1,1<\mathrm{RF} \leq 1,7$ os frutos são oblongos e $\mathrm{RF}>1,7$ os frutos são cilíndricos.

Segundo Miccolis \& Saltveit Junior (1991), se RF = 2,04 apresenta frutos de formato oblongo alongado, $\mathrm{RF}=1,65$ fruto oblongo, $\mathrm{RF}=1,28$ fruto semi-esférico e $\mathrm{RF}=1,01$ fruto totalmente esférico.

De acordo com Cunha (1993), existem índices representativos de formato mais adequados para cada cultivar. Para a cv. Valenciano Amarelo, os mais aceitos estão em torno de 1,0 a 1,2, apresentando formato ligeiramente alongado este último. Para os melões Cantaloupes, são desejados, segundo Foster (1967), índices próximos de 1,0 com formato esférico, porém, frutos ligeiramente oblongos são perfeitamente aceitáveis, já os índices maiores que 1,2 são indesejáveis.

De maneira geral, fruto muito grande, de formato alongado ocupa maior espaço e torna-se mais dificil acondicioná-lo nas respectivas embalagens (Grangeiro et al., 1999).

Variações na relação de formato entre cultivares foram estudadas por Grangeiro et al. (1999) e Gurgel et al. (2000). Além do fator genético, a posição do fruto na planta parece influenciar o seu formato (Gusmão, 2001).

Segundo Brandão Filho \& Vasconcellos (1988), o fruto quando fixado em entrenó muito baixo na planta tutorada ficará pequeno e de formato achatado, ocorrendo o inverso, quando deixado em entrenó muito acima do meio da planta.

Neste trabalho não foi encontrado diferença estatística entre ambas relações K:N tanto para o híbrido Orange Flesh como para o Galileo (Tabela 2). 
$\mathrm{Na}$ Figura 7, é visto que houve grande semelhança nos valores médios da relação de formato, para as soluções 1 e 2, para cada híbrido em questão.

Relação média de formato dos frutos

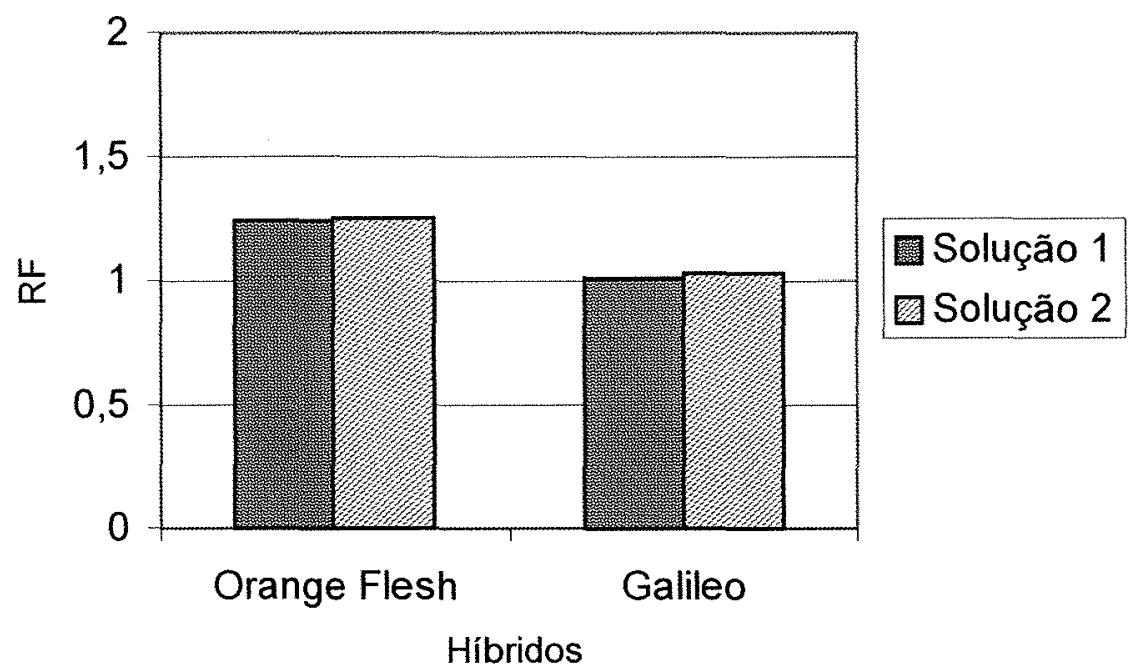

Figura 7- Valores médios da relação de formato dos frutos, nas soluções 1 e 2, para os híbridos Orange Flesh e Galileo, ESALQ-USP, Piracicaba-SP, 2001.

Feitosa Filho et al. (2001a), quando trabalharam com doses de $\mathrm{N}$ e K, aplicadas via fertirrigação em pimentão, verificaram que não houve variabilidade nos dados da relação comprimento:diâmetro, provavelmente esta variável está relacionada mais aos aspectos genéticos inerentes de cada variedade ou cultivar.

No entanto, o híbrido Orange Flesh apresentou relação $R F=1,25$ e 1,24 para as relações $\mathrm{N}: \mathrm{K}$ 1,3:1 e 2,6:1, respectivamente, sugerindo que este híbrido apresenta formato semi-esférico. Enquanto, o híbrido Galileo apresentou relação 1,01 e 1,03 para as relações $\mathrm{K}: \mathrm{N}$ 1.3:1 e 2,6:1, respectivamente, constatando que este híbrido 
apresenta formato totalmente esférico, conforme a classificação sugerida por Miccolis \& Saltveit Junior (1991).

\subsubsection{Espessura distal e espessura polpa}

Para a espessura média distal pode-se observar através da Tabela 2 que não houve efeito estatístico entre ambas soluções, tanto para o híbrido Orange Flesh como para o Galileo.

$\mathrm{Na}$ Tabela 4 é possível verificar a espessura média distal alcançada pelos dois híbridos em ambas soluções.

Tabela 4. Médias observadas nos híbridos Orange Flesh e Galileo para os parâmetros: relação média de formato (RF), espessura média distal (ED), espessura média da polpa (EP), conteúdo médio de sólido solúveis (SS) e firmeza média da polpa (FIR). ESALQUSP, Piracicaba-SP, 2001.

\begin{tabular}{|c|c|c|c|c|c|}
\hline Tratamentos & RF & $\mathrm{ED}(\mathrm{mm})$ & $\begin{array}{l}\text { Médias } \\
\text { EP (mm) }\end{array}$ & SS (\%) & $\mathrm{FIR}(\mathrm{N})$ \\
\hline & \multicolumn{5}{|c|}{ Orange Flesh } \\
\hline Solução 1 & $1,24^{\mathrm{a}}$ & $26,4^{a / 1}$ & $32,5^{b}$ & $11,13^{b}$ & $15,65^{\mathrm{a}}$ \\
\hline Solução 2 & $1,25^{\mathrm{a}}$ & $27,6^{\mathrm{a}}$ & $34,8^{a}$ & $11,86^{\mathrm{a}}$ & $15,66^{\mathrm{a}}$ \\
\hline d.m.s $(5 \%)$ & 0,03 & 0,19 & 0,18 & 0,44 & 1,90 \\
\hline \multirow[t]{2}{*}{ d.m.s $(1 \%)$} & 0,05 & 0,27 & 0,26 & 0,63 & 2,72 \\
\hline & \multicolumn{5}{|c|}{ Galileo } \\
\hline Solução 1 & $1,01^{\mathrm{a}}$ & $27,8^{\mathrm{a}}$ & $36,8^{\mathrm{a}}$ & $11,27^{\mathrm{a}}$ & $6,74^{\mathrm{a}}$ \\
\hline Solução 2 & $1,03^{\mathrm{a}}$ & $26,5^{\mathrm{a}}$ & $33,6^{b}$ & $11,48^{\mathrm{a}}$ & $5,31^{\mathrm{a}}$ \\
\hline d.m.s $(5 \%)$ & 0,04 & 0,21 & 0,22 & 0,91 & 1,79 \\
\hline d.m.s $(1 \%)$ & 0,06 & 0,35 & 0,37 & 1,51 & 2,95 \\
\hline
\end{tabular}

$/ 1$ Médias seguidas da mesma letra não diferem estatisticamente entre si pelo teste de Tukey a $5 \%$.

A Figura 8 mostra certa semelhança na espessura média distal existente entre as soluções 1 e 2 , para cada híbrido analisado. 
Espessura média distal dos frutos

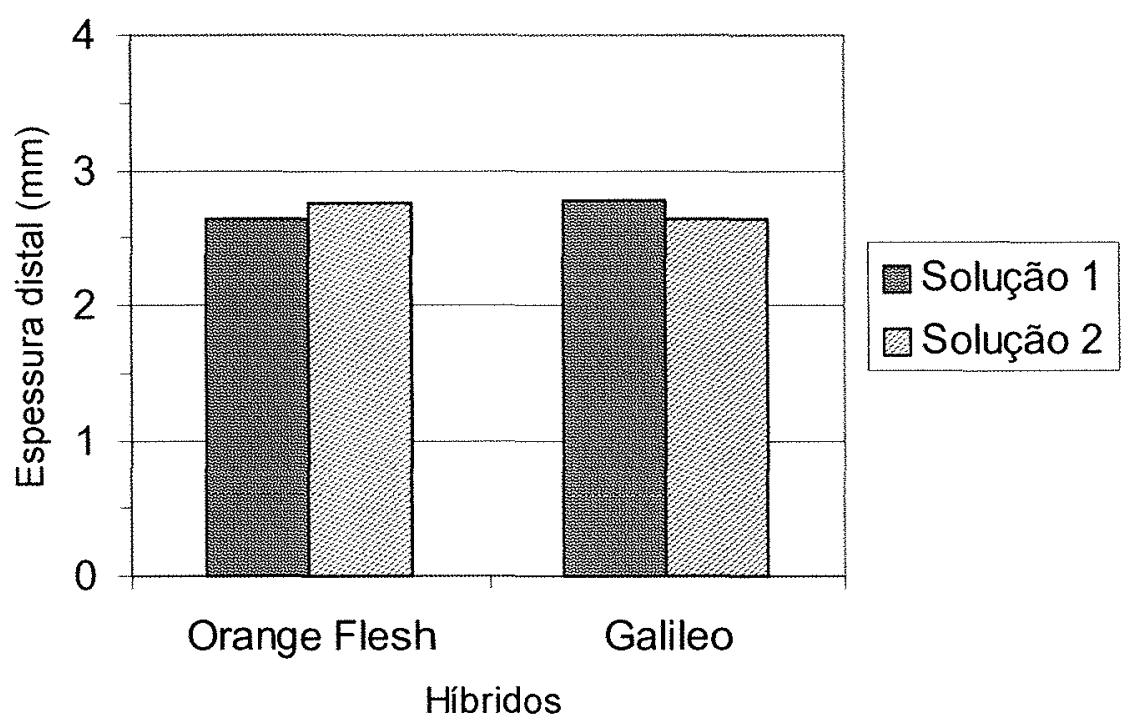

Figura 8-Espessura média distal, nas soluções 1 e 2, para os híbridos Orange Flesh e Galileo, ESALQ-USP, Piracicaba-SP, 2001.

Por outro lado, o efeito das diferentes soluções (relação $\mathrm{K}: \mathrm{N}$ ) interferiu na espessura média da polpa dos frutos. Verifica-se, por intermédio da Tabela 2, que houve diferença significativa entre as soluções 1 e 2 para o híbrido Orange Flesh ao nível de $5 \%$ de probabilidade e para o híbrido Galileo ao nível de $1 \%$ de probabilidade.

Na Tabela 4 são observados os resultados referentes à espessura média da polpa, medida na região equatorial dos frutos. Nota-se que o híbrido Orange Flesh apresentou polpa mais espessa na relação $K: N$ 2,6:1 do que na relação $K: N$ 1,3:1, havendo acréscimo na espessura média da polpa aproximadamente de $6,6 \%$ na solução 2, em relação a 1. Enquanto, para o híbrido Galileo, o efeito foi inverso, ou seja, a polpa foi mais espessa na relação $\mathrm{K}: \mathrm{N}$ 1,3:1 do que na 2,6:1, havendo acréscimo na espessura da polpa de aproximadamente $8,7 \%$ na solução 1 em relação a 2 . 
Soares (2001), com melão em cultivo protegido sob quatro doses de $\mathrm{K}$ aplicadas via fertirrigação, não observou uma tendência clara na obtenção de frutos com polpa mais espessa, com o aumento das doses de $\mathrm{K}$.

A espessura média da polpa do híbrido Orange Flesh encontrada neste trabalho para as relações $\mathrm{K}: \mathrm{N}$ 1,3: e 2,6:1 foi de 32,50 e 34,80mm, respectivamente, bem superiores ao reportado por Fernandes (1996), quando caracterizou os frutos do mesmo híbrido, apresentando espessura da polpa na região equatorial de $29,0 \mathrm{~mm}$.

Através da Figura 9, é possível verificar graficamente a espessura média da polpa dos frutos, nas soluções 1 e 2 , para cada híbrido analisado.

Espessura média da polpa dos frutos

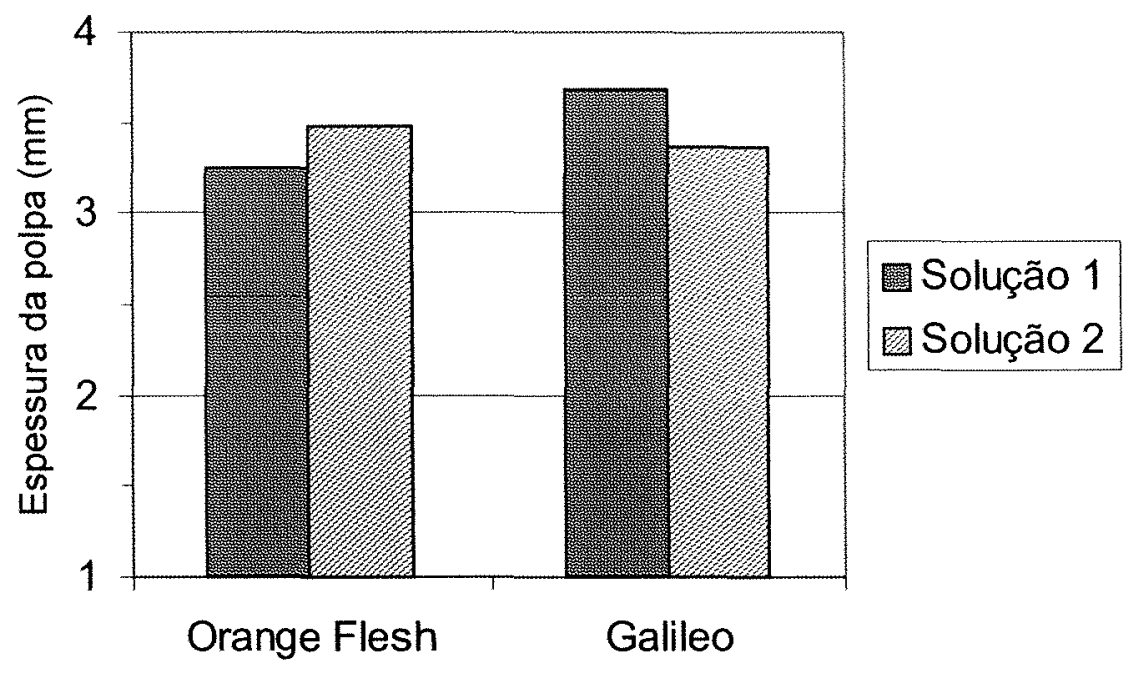

Hibridos

Figura 9- Espessura média da polpa, nas soluções 1 e 2, para os híbridos Orange Flesh e Galileo, ESALQ-USP, Piracicaba-SP, 2001. 
Para o híbrido Galileo, a espessura média da polpa na colheita, para as soluções 1 e 2 foi de 36,80 e 33,60mm, respectivamente, é inferior ao encontrado por Menezes (1996) em melão tipo Galia cv. Melina, cuja espessura média da polpa foi $46 \mathrm{~mm}$.

\subsubsection{Conteúdo de sólido solúveis dos frutos}

As características físicas (tamanho e formato do fruto) e químicas (teor de sólidos solúveis e $\mathrm{pH}$ ) determinam a qualidade visual e sabor do produto (Lopes, 1982). Dentre esses caracteres, o teor de sólidos solúveis é a variável mais importante na determinação da qualidade do melão, porém, a firmeza e coloração devem ser fatores complementares de qualidade (Yamaguchi et al., 1977). Este caracter pode variar tanto entre talhões, como entre frutos da mesma planta e até entre diferentes partes do mesmo fruto (Scott \& MacGillivray, 1940). Contudo, o conteúdo de sólido solúveis, em alguns casos estudados, tem sido considerado um indicador deficiente de qualidade para o melão (Aulenbach \& Worthington, 1974; Yamaguchi et al., 1977; Cohen \& Hickis, 1986).

Segundo Grangeiro et al. (1999), o conteúdo de SS é um parâmetro muito importante, pois, juntamente com a coloração do fruto é utilizado como indicador do ponto de colheita. Além disso, é o principal critério utilizado no estabelecimento de padrões de qualidade nas regulamentações de mercado.

Neste trabalho, o efeito das diferentes soluções (relação K:N) interferiu no conteúdo médio de sólido solúveis (SS) dos frutos. Verifica-se por intermédio da Tabela 2, que houve diferença significativa entre as soluções 1 e 2 para o híbrido Orange Flesh, no entanto, pode-se verificar que não houve efeito estatístico em relação ao híbrido Galileo.

Nota-se pela análise da Tabela 4, que o híbrido Orange Flesh obteve maior conteúdo SS com a solução 2 do que com a solução 1 (11,86 e 11,13\%, respectivamente). Havendo acréscimo aproximadamente de 19,7\% no conteúdo de SS do fruto na solução 2 em relação a solução 1 . 
Estes dados do híbrido Orange Flesh concordam com Prabhakar et al. (1985), que observaram a aplicação de K com efeito significativo, elevando o conteúdo de sólido solúveis dos frutos de melão cultivados no solo. Os dados, por outro lado, descordam com Soares (2001) e Pinto et al. (1996a), (1996b), (1995) e (1993) que trabalhando com melão em solo e doses de $\mathrm{K}$, aplicadas via fertirrigação, não verificaram alterações no conteúdo de sólido solúveis nos frutos. Hernandez et al. (1995) concluíram que a ausência da aplicação de fertilização com $\mathrm{K}$, em cultivo de melão no solo, sob ambiente protegido, não alterou o conteúdo de sólido solúveis do fruto, porém, os autores salientam a alta disponibilidade de $\mathrm{K}$ no solo onde foi desenvolvido o estudo.

Costa (1999), trabalhando com tomate em vasos contendo vermiculita e recebendo solução nutritiva por inundação através de sistema fechado de circulação, observou que não houve diferença significativa entre as doses de $\mathrm{K}$ testadas, quanto ao conteúdo de SS. Hartz et al. (1999), trabalharam com doses de K para determinar a máxima qualidade de frutos de tomate para processamento industrial verificaram fraca correlação com SS.

Sousa (2000), trabalhando em solo com níveis de irrigação e doses de K via fertirrigação por gotejamento no maracujazeiro amarelo não constatou efeito significativo no conteúdo de SS.

Feitosa Filho et al. (2001b), cultivando banana com o objetivo de avaliar o efeito da redução de 25 e $50 \%$ das doses de $\mathrm{N}$ e $\mathrm{K}$ aplicadas via fertirrigação em relação às recomendadas para a adubação convencional, constataram que a redução em até $50 \%$ da dose de $\mathrm{K}$ não interferiu estatisticamente no conteúdo de sólido solúveis entre os tratamentos

A Figura 10 representa graficamente o conteúdo médio de SS nos frutos, para as relações K:N 1,3:1 e 2,6:1, para o híbrido Orange Flesh $(11,13$ e 11,86\%) e Galileo $(11,27$ e $11,48 \%)$, respectivamente. 
Conteúdo médio de SS dos frutos

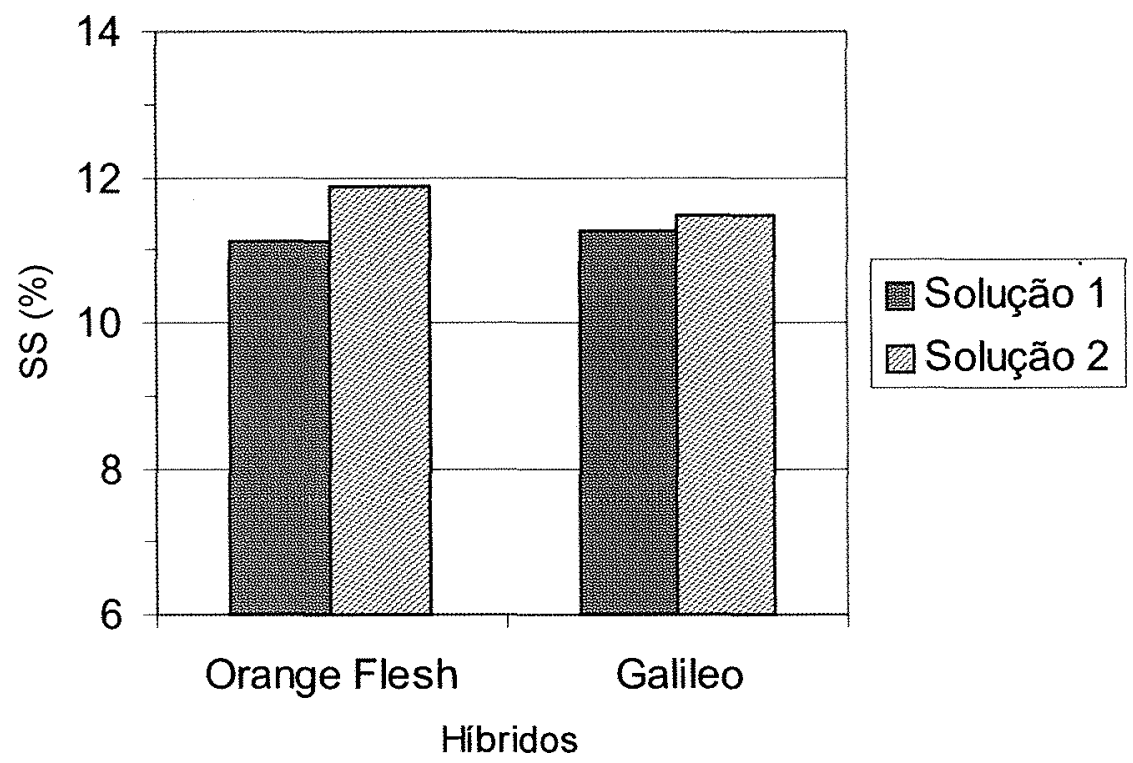

Figura 10- Conteúdo médio de SS, nas soluções 1 e 2, para os híbridos Orange Flesh e Galileo, ESALQ-USP, Piracicaba-SP, 2001.

De acordo com Filgueiras et al. (2000), os requisitos mínimos de qualidade estabelecem que o conteúdo de SS deve ser de pelo menos $9 \%$, porém, quanto mais doce o melão melhor será o seu valor de mercado. Desta forma, os resultados obtido neste trabalho para os híbridos Orange Flesh e Galileo, em ambas soluções, estão bem acima do mínimo exigido. Por outro lado, é recomendado, quanto ao conteúdo de SS, para os melões Orange Flesh e Galia destinados ao mercado externo os valores de $10-13 \%$ e $12-14 \%$, respectivamente (Filgueiras et al., 2000).

Desta forma, os valores encontrados pelo híbrido Orange Flesh estão dentro do recomendado, mas o mesmo não ocorre para o Galileo. No entanto, valores ainda mais inferiores aos encontrados neste trabalho são reportados por Martins et al. 
(1998), em estufa plástica, trabalhando com a cv. Melina (melão tipo Galia), o qual, apresentou frutos com valor médio de 9,1\%. Artés et al. na região de Múrcia, Espanha, obtiveram 10,8\% de conteúdo médio de SS para melão tipo Galia. Menezes (1996) e Cocozza (1997) em cultivo à campo de melão tipo Galia, obtiveram valores próximos de 8 e $6 \%$, respectivamente.

Valores superiores aos obtidos neste trabalho são reportados por Mendlinger (1994) e Aharoni et al. (1993), em estudo sobre qualidade de melão Galia, que verificaram, para o tratamento controle, 14,6 e 12,5\%, respectivamente.

Pode ter ocorrido redução do conteúdo de SS durante o período de armazenamento dos frutos em câmara fria, pois segundo Menezes et al. (1998b), a redução no conteúdo de SS é mais pronunciada durante os primeiros cinco dias de armazenamento. Esta redução pode ser atribuída ao consumo de açúcares via mecanismo respiratório. Ao contrário de frutos climatéricos, como a banana e a maçã que armazenam apreciáveis quantidades de amido, para a conversão em açúcares durante o armazenamento, o melão requer fornecimento de fotoassimilados para acumular açúcares durante o amadurecimento (Hubbard et al., 1989). Isto é reforçado nas pesquisas de Shillie \& Saltveit Junior (1993), em que a concentração de SS aumentou de $7,1 \%$ para 9,4\% (34 e 42 dias após polinização, respectivamente), quando o fruto amadureceu preso à planta, porém, não houve mudanças em fruto amadurecido fora da planta.

Guis et al. (1997) confirmam esta tendência, onde frutos de melão com inibidor de etileno continuaram fixados as plantas, acumulando mais açúcares que aqueles frutos controle que desprenderam-se da planta com antecedência. Os autores verificaram que o rápido aumento em conteúdo de sólido solúveis durante o amadurecimento foi inteiramente devido a sacarose, e sendo assim, a prematura colheita de frutos é prejudicial para a qualidade dos frutos. 


\subsubsection{Firmeza da polpa}

Quanto à firmeza dos frutos, esta não deve ser nem muito dura, nem tenra demais, condições que alteram o sabor do fruto (Bleinroth,1994). Sob o ponto de vista de manuseio pós-colheita, a firmeza é essencial, em razão de frutos com maior firmeza serem mais resistentes às injúrias mecânicas, a que os mesmos estão sujeitos durante o transporte e comercialização (Grangeiro et al., 1999). É também um atributo de qualidade importante, pois, está associada com textura/aroma, uma vez que a liberação de compostos presentes no produto que são perceptíveis pelo paladar, estão também relacionados com a estrutura do tecido (Chitarra \& Chitarra, 1990).

A metodologia utilizada nas avaliações pode proporcionar também diferenças nos resultados, mesmo que seja realizada com os mesmos genótipos. Entretanto, é importante, para esse tipo de avaliação, observar o diâmetro da ponta do penetrômetro, se a casca foi removida ou não, a posição e o local no fruto em que foram feitas as determinações (Kader, 1978).

$\mathrm{O}$ efeito das diferentes soluções (relação $\mathrm{K}: \mathrm{N}$ ) não influenciou na firmeza média da polpa dos frutos. Verifica-se por intermédio da Tabela 2 que não houve efeito estatístico entre as soluções 1 e 2 , para ambos híbridos analisados.

A Tabela 4 mostra que, de modo geral, o híbrido Orange Flesh apresentou semelhante firmeza nas duas soluções estudadas. $O$ híbrido Galileo apresentou uma forte tendência $(21,2 \%)$ a diminuir sua firmeza média da polpa, com o aumento da relação $\mathrm{K}: \mathrm{N}$.

Segundo Arnon (1966), resultados de pesquisa fundamentado na fertilização potássica e nitrogenada com relação a firmeza da polpa de frutos são inconsistentes, talvez refletindo a vários graus de desequilíbrio entre $\mathrm{N}, \mathrm{K}$ e $\mathrm{P}$.

Para os híbridos Orange Flesh e Galileo, através da Figura 11, é possível verificar graficamente a firmeza média da polpa dos frutos, para as soluções 1 e 2.

A firmeza média da polpa para os híbridos Orange Flesh $(15,65$ e 15,66N) e Galileo $(6,74$ e 5,31N), para as soluções 1 e 2 , respectivamente, foram bem inferiores ao recomendado por Filgueiras et al. (2000), para a ocasião da colheita de frutos destinados 
à exportação, cujos valores são 30 e $22 \mathrm{~N}$, respectivamente. Isto foi intencional, visto que objetivo deste trabalho foi de produzir frutos próximos do mercado consumidor e como o número de frutos a serem avaliados foi elevado, desta forma seria possível o consumo imediato dos frutos ao invés de desprezá-los após análise. Além disso, os frutos foram armazenados à cerca de $7^{\circ} \mathrm{C}$ em câmara com circulação de ar frio, durante aproximadamente 5 dias, possivelmente contribuindo ainda mais, para a redução da firmeza da polpa dos frutos.

Firmeza média da polpa dos frutos

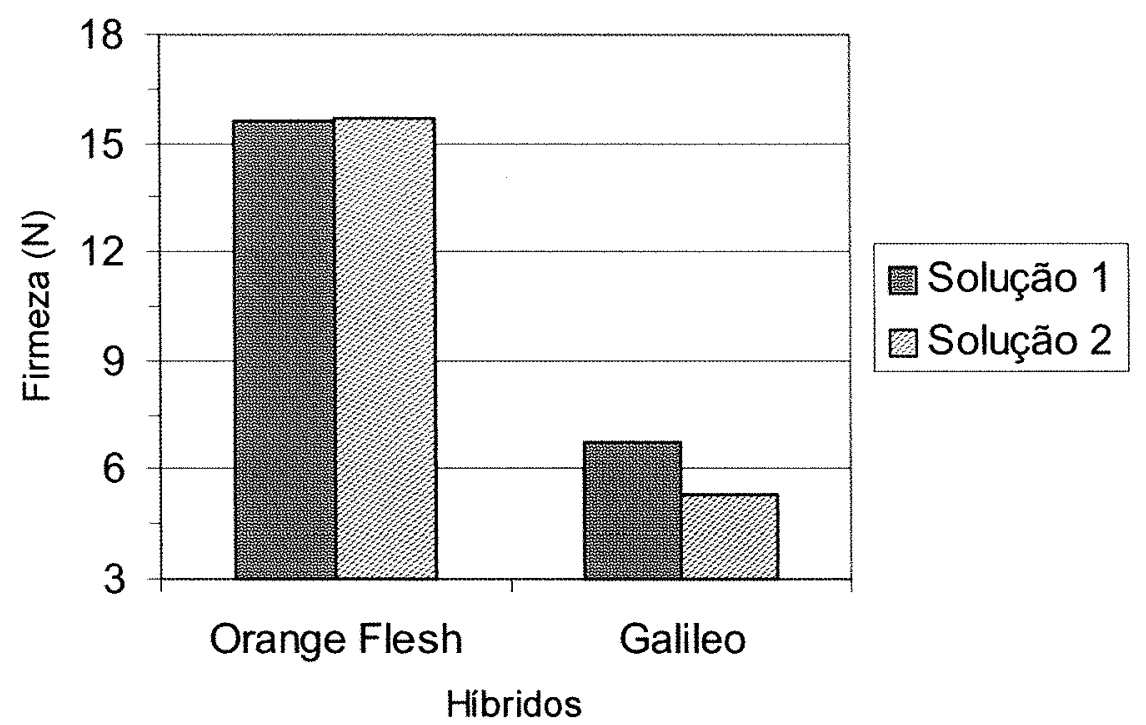

Figura 11- Firmeza médio da polpa, nas soluções 1 e 2, para os híbridos Orange Flesh e Galileo, ESALQ-USP, Piracicaba-SP, 2001.

Segundo Lester \& Shellie (1992), melões tipo Honey Dew, totalmente maturos, avaliados 10 dias após armazenamento a cerca de $18^{\circ} \mathrm{C}$, apresentaram valor de $16,45 \mathrm{~N}$ de firmeza da polpa. Lester (1998), obteve de melão Honey Brew tipo Honey 
Dew, 50 dias após antese colhido e armazenado durante 7 dias a $10^{\circ} \mathrm{C}$ e $90 \%$ UR firmeza de aproximadamente $14 \mathrm{~N}$.

O amolecimento dos frutos durante a maturação, é atribuída à hidrólise de vários polissacarídios estruturais, sendo as substâncias pécticas os principais (Menezes et al., 1998a). Guis et al. (1997) observaram similar tendência em melões transgênicos com inibidor de etileno, onde a supressão da produção de etileno tem resultado em quase completa inibição do amolecimento da polpa do fruto, indicando que o amolecimento é engatilhado pelo etileno. Apesar das tentativas de elucidar o mecanismo envolvido no amolecimento do melão (Lester, 1988; Lester, 1990), pouco se sabe a cerca da atuação de enzimas diretamente relacionadas com o processo.

A comercialização de melões nobres tem sido prejudicada pela alta perecibilidade, com vida útil pós-colheita não ultrapassando 14 dias (Lester \& Stein, 1993).

Menezes et al. (1998a) obtiveram redução de 54\% na firmeza da polpa dos frutos de melão tipo Galia do estádio de maturação I até o V.

Aharoni et al.(1993) também detectaram acentuada redução na firmeza da polpa do melão tipo Galia, quando estudaram o comportamento pós-colheita durante o armazenamento refrigerado a $6^{\circ} \mathrm{C}$ e UR de $94 \%$, em atmosfera controlada $\left(10 \% \mathrm{CO}_{2}\right.$ e $10 \% \mathrm{O}_{2}$ ) e com absorvente de etileno. Observaram a suscetibilidade ao amolecimento dos melões nobres, visto que mesmo armazenados a $6^{\circ} \mathrm{C}$ a firmeza da polpa reduziu.

De acordo com Gomes Júnior et al. (2001), a firmeza da polpa de melão tipo Galia decresceu linearmente ao longo do período de armazenamento independente do estádio de maturação. Por ocasião da colheita, a firmeza da polpa foi 30,07 e 17,87N, reduzindo-se para $5,32 \mathrm{~N}$ e $3,5 \mathrm{~N}$ no final do período experimental ( 25 dias), para os frutos colhidos no estádio II e IV de maturação, respectivamente. 


\section{CONCLUSÕES}

- Os híbridos Orange Flesh e Galileo adaptaram-se bem ao cultivo hidropônico em NFT, sendo o NFT, técnica viável para o cultivo de melão em hidroponia.

- O uso da solução nutritiva com relação $\mathrm{K}: \mathrm{N} 2,6: 1$ proporciona ao híbrido Orange Flesh aumento no peso médio do fruto, comprimento médio, diâmetro médio, diâmetro médio da cavidade e espessura média da polpa.

- O híbrido Orange Fresh obtêm maior conteúdo médio de SS na solução nutritiva com relação $\mathrm{K}: \mathrm{N} 2,6: 1$.

- O ganho de peso médio do fruto para o híbrido Orange Flesh na solução nutritiva com relação $\mathrm{K}: \mathrm{N}$ 2,6:1 é devido principalmente ao aumento em espessura média da polpa, seguido do comprimento e diâmetro médio do fruto.

- O híbrido Galileo apresenta comportamento praticamente semelhante nas relações K:N 2,6:1 e 1,3:1.

- O uso da solução nutritiva com relação K:N 1,3:1 proporcionou ao híbrido Galileo maior espessura média da polpa. 
ANEXOS 


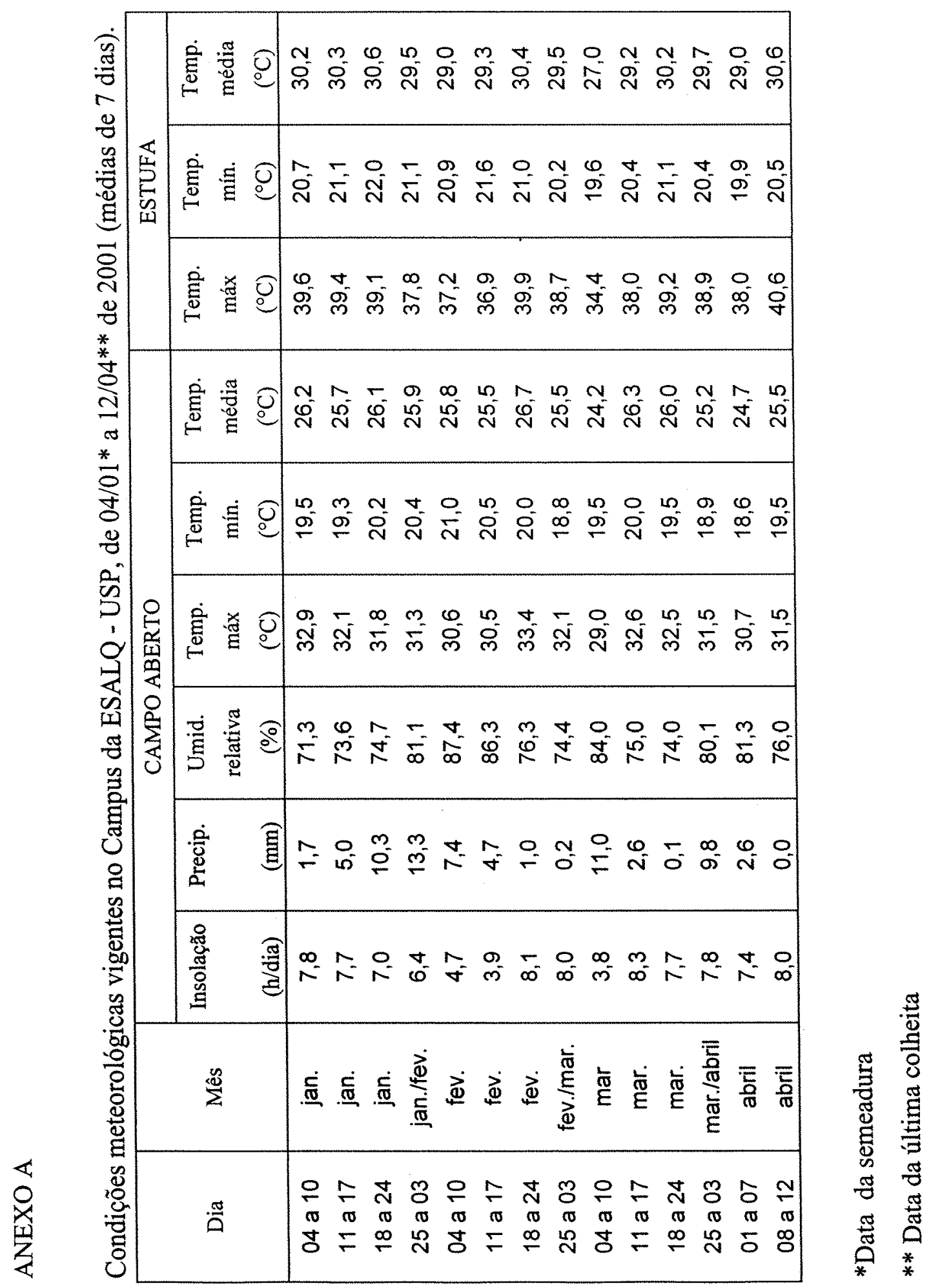




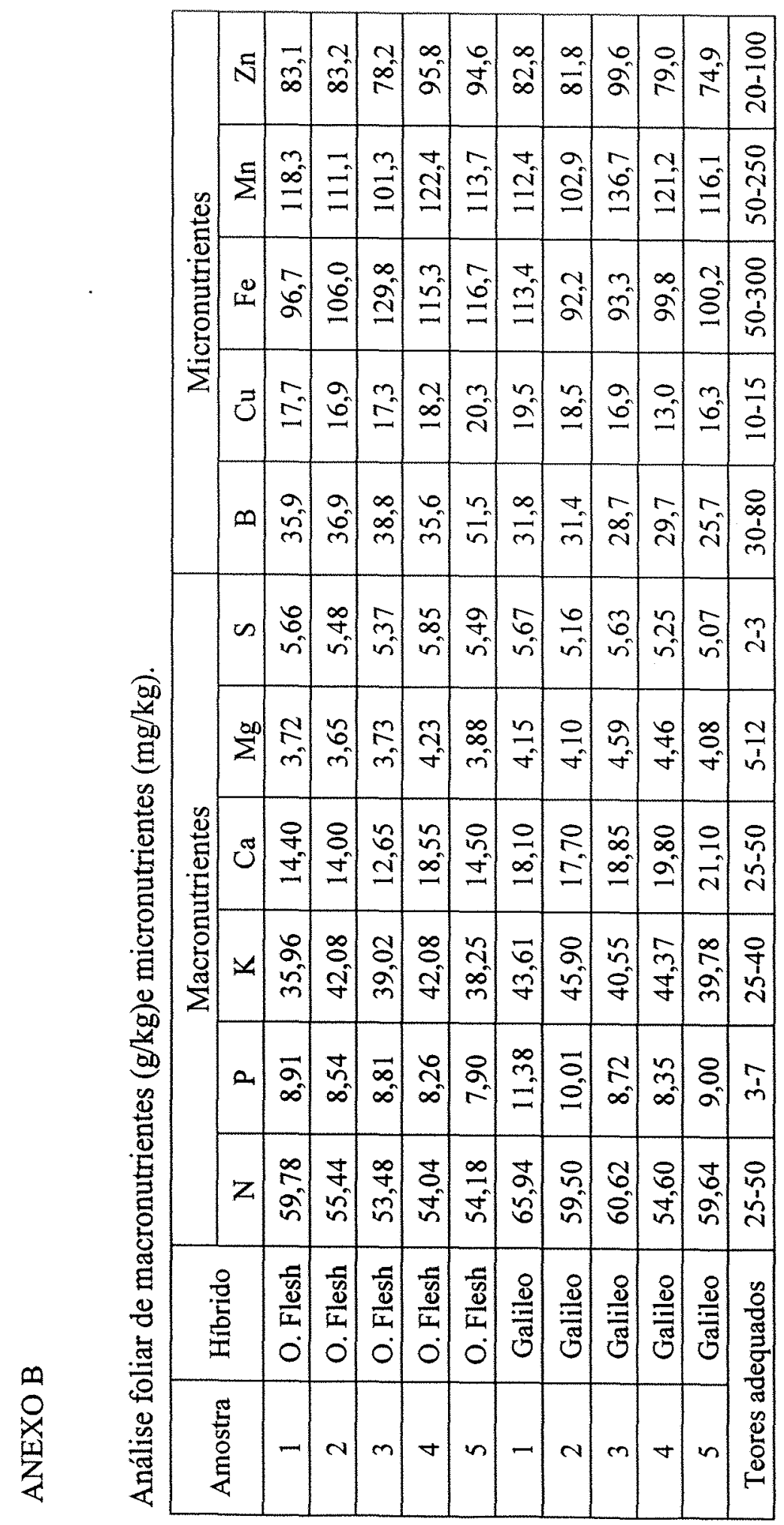




\begin{tabular}{|c|c|c|}
\hline & 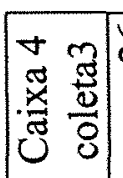 & 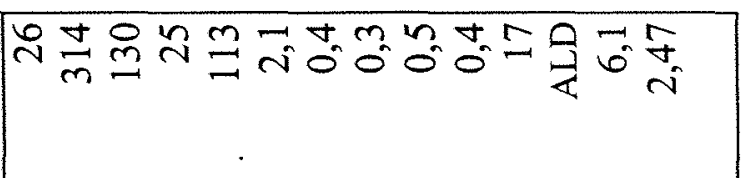 \\
\hline & 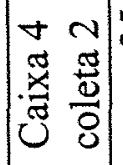 & $m \underset{m}{m}$ 응 \\
\hline & 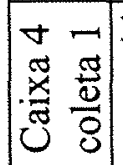 & 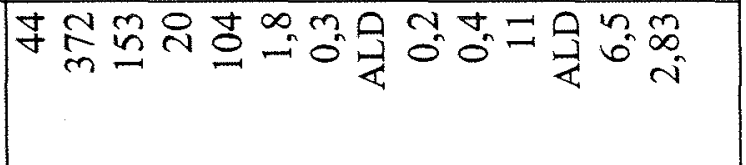 \\
\hline & 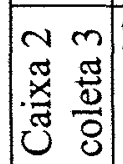 & तิ \\
\hline & 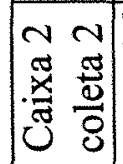 & 施 \\
\hline & 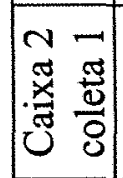 & 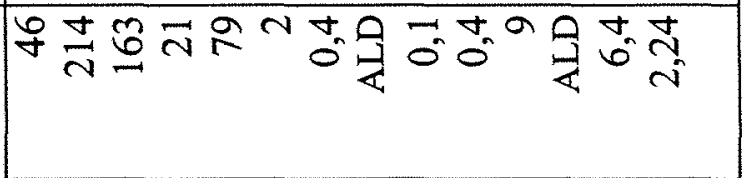 \\
\hline 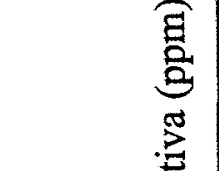 & 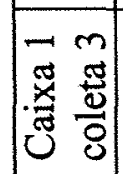 & 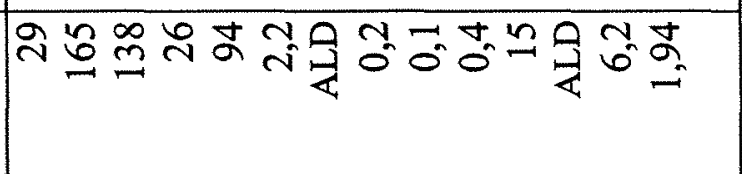 \\
\hline 禜 & 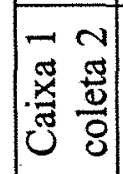 & mूa \\
\hline 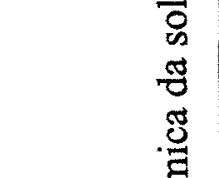 & 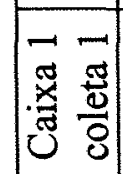 & 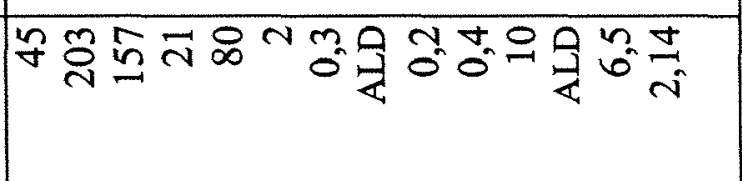 \\
\hline 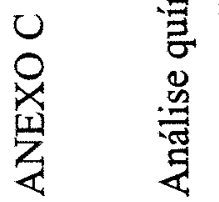 & 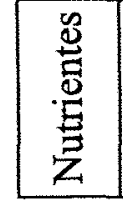 & L \\
\hline
\end{tabular}


ANEXO D

Fotos referentes ao experimento

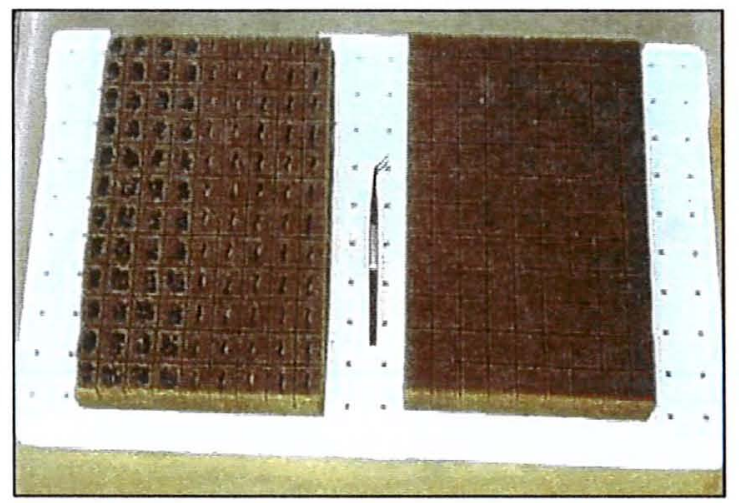

Semeadura em espuma fenólica

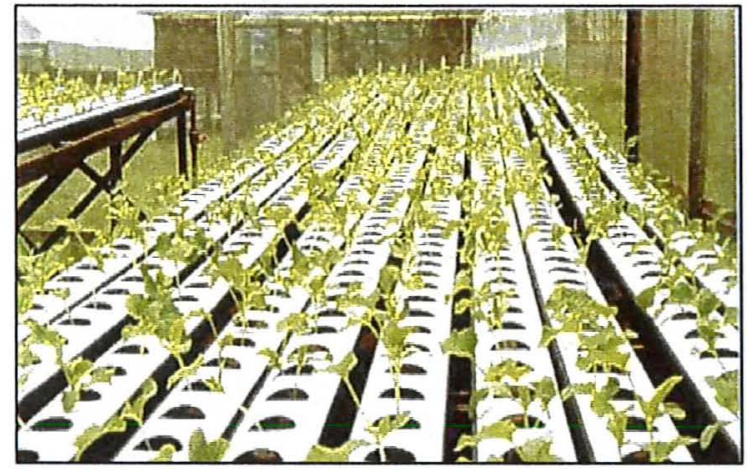

Mudas transplantadas no berçário

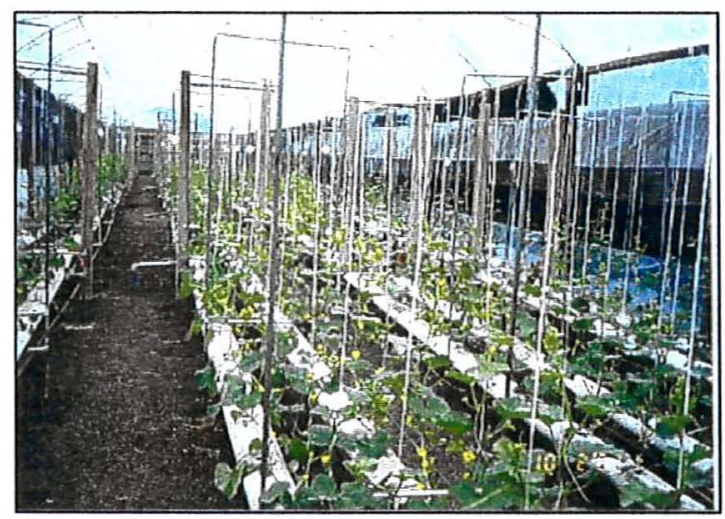

Plantas na estufa definitiva, aos 37 dias após a semeadura

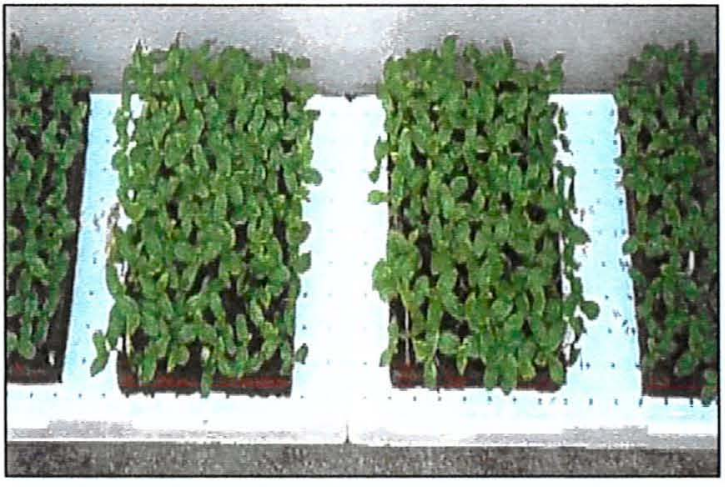

Mudas aos 13 dias após a semeadura

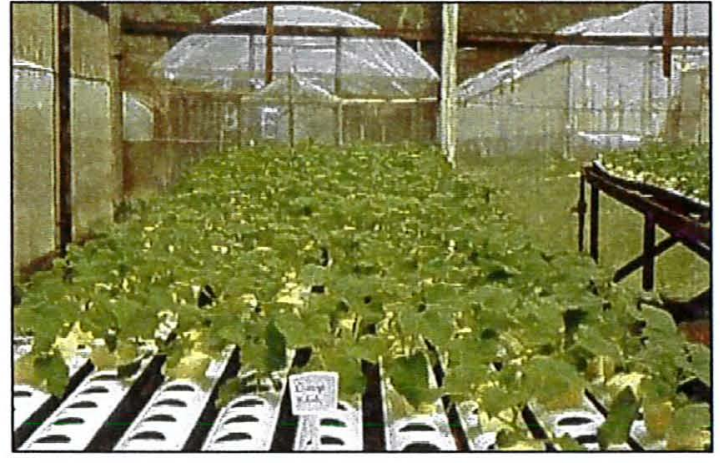

Mudas aos 25 dias após a semeadura

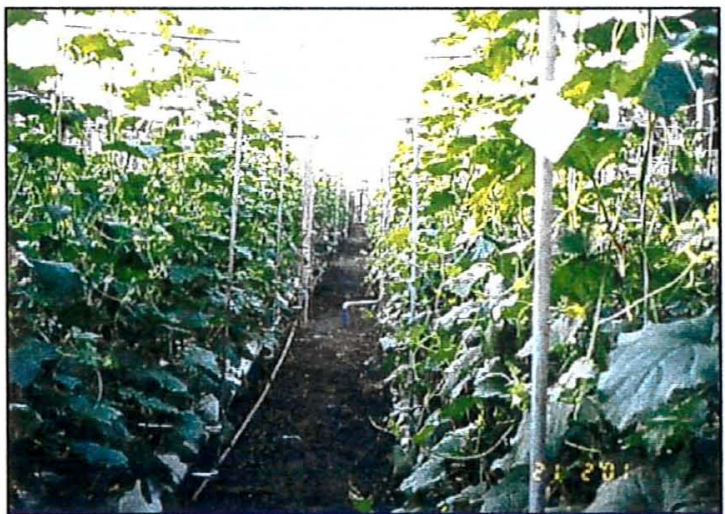

Plantas aos 48 dias após a semeadura, antes da poda e da desbrota dos ramos 


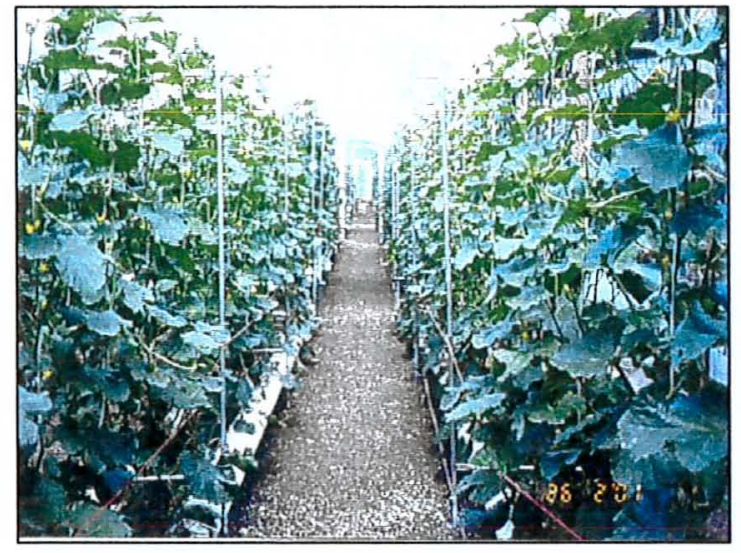

Cultura aos 53 dias após a semeadura

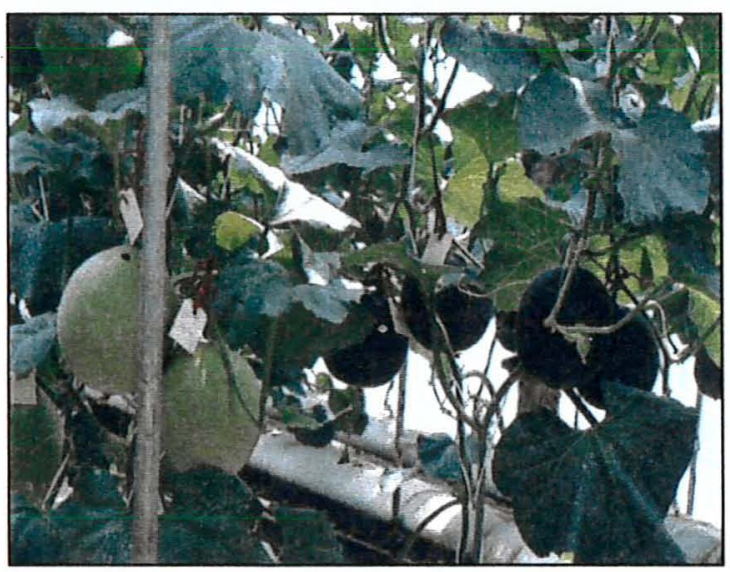

Frutos com cerca de 16 dias após a polinização

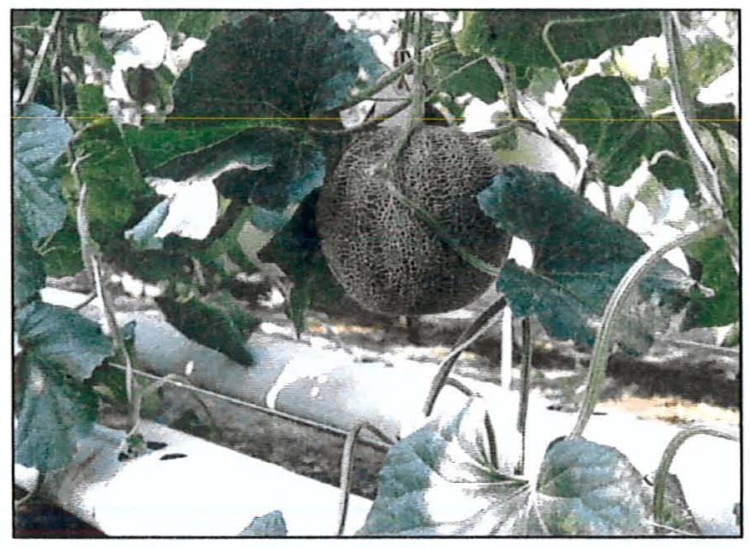

Híbrido Galileo totalmente rendilhado

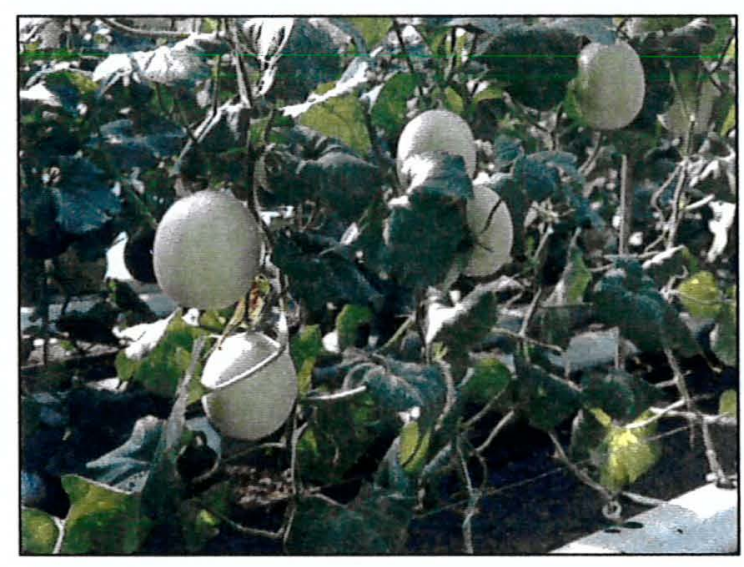

Híbrido Orange Flesh 37 dias após a polinização

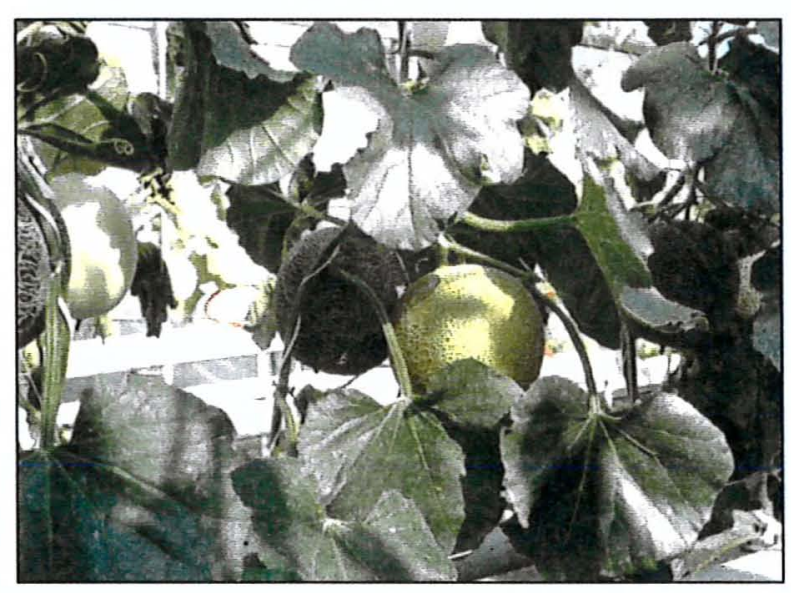

Mudança na coloração da casca do híbrido Galileo 


\section{REFERÊNCIAS BIBLIOGRÁFICAS}

ADAMS, P. Crop nutrition in hydroponics. Acta Horticulturae, n.323, p.289-305, 1992. / Symposium on Soil and Soilless Media Under Protected Cultivation in Mild Winter Climates, Cairo, $1992 /$

ADAMS, P. Nutrition of greenhouse vegetables in NFT and hidroponic systems. Acta Horticulturae, n.361, p.245-257, 1994. / International Symposium on New Cultivation Sustems in Greenhouse, Cagliari, 1993 /

AHARONI, Y.; COPEL, A.; FALLIK, E. Storing "Galia" melons in a controlled atmosphere with ethylene absorbent. HortScience, v.28, n.2, p.725-726, July 1993.

ALVES, R.E. (Org.) Melão: pós colheita. Brasília: Embrapa Comunicação para Transferência de Tecnologia, 2000. 43p. (Frutas do Brasil,10).

ANDRIOLO, J.L. Fisiologia das culturas protegidas. Santa Maria: UFSM, 1999. 142p. (Série Divulgação Científica).

ARNON, I. Quality criteria of agricultural produce and the influence of mineral fertilizers on quality. In: CONGRESS OF THE INTERNATIONAL POTASH INSTITUTE, 8, Brussels, 1966. Potassium and the quality of agricultural products: proceedings. Brussels: International Potash Institute, 1966. p.339-400. 
ARTÉS, F.; ESCRICHE, A.J.; MARTÍNEZ, J.A.; MARÍN, J.G. Quality factors in four varieties of melon (Cucumis melo L.). Journal of Food Quality, v.16, p.91$100,1993$.

ASHER, C.J. Limiting external concentrations of trace elements for plant growth: use of flowing solution culture techniques. Journal of Plant Nutrition, v.3, n.1/4, p.163-180, 1981.

AULENBACH, B.B.; WORTHINGTON, J.T. Sensory evaluation of muskmelon: Is soluble solids content a good quality index? HortScience, v.9, n.2. p.136-137, Apr. 1974.

BELFORT, C.C.; HAAG. H.P.; MINAMI, K. Nutrição mineral de hortaliças. LXXII. Diagnóstico das carências de macronutrientes e de boro em melão (Cucumis melo L.). Anais da Escola Superior de Agricultura "Luiz de Queiroz", v.43, n.2, p. $365-377,1986 b$.

BELFORT, C.C.; HAAG. H.P.; MATSUMOTO, T.; CARMELLO, Q.A.C.; SANTOS, J.W.C. Nutrição mineral de hortaliças. LXX. Acumulação de matéria seca e recrutamento de macronutrientes pelo melão (Cocumis melo L. cv. Valenciano Amarelo CAC) cultivado em latossolo vermelho em Presidente Venceslau, SP. Anais da Escola Superior de Agricultura “Luiz de Queiroz", v.43, n.1, p.159-219, $1986 a$.

BENOIT, F. Pratical guide for simple soilles culture techniques. Sint-katelijneWaver: European Vegetable R \& D. Centre, 1992. 72p.

BERNADAC, A.; JEAN-BAPTISE, I.; BERTONI, G.; MORARD, P. Changes in calcium contents during melon (Cucumis melo L.) fruit development. Scientia Horticulturae, v.66, p.181-189, 1996. 
BLEINROTH, E.W. In: GORGATTI NETTO, A.; GAYET, J.P.; BLEINROTH, W.E.; MATAllo, M.; GARCIA, E.E.C.; GARCIA, A.E.; ARDITO, E.F.G.; BORDIN, M.R. Melão para exportação: procedimentos de colheita e pós-colheita. Brasília: Embrapa, 1994. cap.2, p.11-21. (Série Publicações Técnicas FRUPEX, 6).

BLISKA JÚNIOR. A.; HONÓRIO, S.L. Manual tecnológico: hidroponia. Campinas: Unicamp;Feagri, 1997. 28p.

BRANDÃO FILHO, J.U.T.; VASCONCELLOS, M.A.S. A cultura do meloeiro. In: GOTO, R.; TIVELli, S.W. (Org.). Produção de hortaliças em ambiente protegido: condições subtropicais. São Paulo: Editora da UNESP, 1998. cap.6, p.161-193.

CARMELlO, Q.A.C.; FURLANI, P.R. Hidroponia: cultivo de plantas sem solo. Piracicaba: ESALQ; Sebrae, 1994. $41 \mathrm{p}$.

CARNEIRO FILHO, J. Produção e qualidade de frutos de melão cantaloupe influenciados pela poda e pelo tutoramento, em condições de estufa e de campo. Viçosa, 2001. 102p. Dissertação (M.S.) - Universidade Federal de Viçosa.

CASTELlANE, P.D.; ARAUJO, J.A.C.de Cultivo sem solo: hidroponia. Jaboticabal: FUNEP, 1995. 43p.

CHITARRA, M.I.F.; CHITARRA, A.B. Pós-colheita de frutos e hortaliças: fisiologia e manuseio. Lavras:ESAL;FAEPE, 1990. 320p.

COCOZZA, F.D.M. Aplicação pós-colheita de quelato de cálcio e boro em melão Galia: desenvolvimento e qualidade dos frutos. Lavras, 1997. 78p. Dissertação (M.S.) - Universidade Federal de Lavras. 
COHEN, R.A.; HICKS, J.R. Effect of storage on quality and sugar in muskmelon. Journal of the American Society for Horticultural Science, v.111, n.4, p.553-557, 1986.

COSTA, P.C. Relações N:K:Ca na qualidade de frutos de tomateiro (Lycopersicon esculentum Mill.) híbrido Momotaro, em cultivo hidropônico. Botucatu, 1999. 72p. Dissertação (Mestrado) - Faculdade de Ciências Agrárias e Veterinárias, Universidade Estadual Paulista "Julio de Mesquita Filho".

CUNHA, P.M.G. Efeito do ácido giberélico sobre algumas caracteríticaspós-colheita do melão cv. Valenciano Amarelo. Mossoró, 1993. 34p. Monografia (Graduação) Escola Superior de Agricultura de Mossoró.

ECONOMAKIS, C.; DASKALAKI, A.; BITSAKI, A. Efect of the nutrient solution potassium concentrations on tomatoes grown on new or reused Pumice. Acta Horticulturae, n.548, p.511-515, 2001. / International Symposium On Growing Media \& Hidroponics, Macedonia, 1999/

FACTOR, T.L. Comportamento do meloeiro em cultivo protegido, sob dois tipos de cobertura. Jaboticabal, 2000. 77p. Monografia (Graduação) - Faculdade de Ciências Agrárias e Veterinárias, Universidade Estadual Paulista "Julio de Mesquita Filho".

FEITOSA FILHO, J.C.; CAVALCANTE, L.F.; LEITE JUNIOR, G.P.; LOPES, W.F.; SANTOS, C.S.; LOPES, W.F.; PINTO, J.M. Estudos de doses de nitrogênio e de potássio aplicadas no pimentão por fertirrigação em comparação à adubação convencional. In: WORKSHOP DE FERTIRRIGAÇÃO, 2., São Pedro, 2001. Artigos científicos. Piracicaba: ESALQ;LER, 2001a. p.32-47.

FEITOSA FILHO, J.C.; CAVALCANTE, L.F.; LOPES, W.F.; SANTOS, C.S.; LEITE JUNIOR, G.P.; LOPES, W.F.; PINTO, J.M. Estudos de doses de nitrogênio 
e de potássio aplicadas em banana por fertirrigação em comparação à adubação convencional. In: WORKSHOP DE FERTIRRIGAÇÃO, 2., São Pedro, 2001. Artigos científicos. Piracicaba: ESALQ;LER, 2001b. p.48-66.

FERNANDES, P.M.G.C. Armazenamento ambiente e refrigerado de melão, híbrido Orange Flesh, submetido à aplicação pós-colheita de cloreto de cálcio. Lavras, 1996. 45p. Dissertação (Mestrado) - Universidade Federal de Lavras.

FILGUEIRA, F.A.R. Novo manual de olericultura: agrotecnologia moderna na produção e comercialização de hortaliças. Viçosa: Editora UFV, 2000. cap.10, p.333338: Curcubitáceas/Melão.

FILGUEIRAS, H.A.C.; MENEZES, J.B.; ALVES, R.E.; COSTA, F.V. da; PEREIRA, L.S.E.; GOMES Jr., J. Colheita e manuseio pós-colheita. In: ALVES, R.E. (Org.). Melão: pós-colheita. Brasília: Embrapa, 2000. cap.3, p.23-40. (Frutas do Brasil, 10).

FNP CONSULTORIA \& COMÉRCIO, AGRIANUAL 2002: anuário estatístico da agricultura brasileira. São Paulo, 2002. p.412 - 416: Melão.

FOSTER, R.E. F1 hybrid muskmelons, I superior performance of selected hybrids. Proceedings of the American Society for Horticultural Science, v.91, p.390-395, 1967.

FRANCO, J.A.; ESTEBAN, C.; RODRIGUEZ, C. Effects of salinity on various growth stages of muskmelon cv. Revigal. Journal of Hortcultural Science, v.68, n.6, p.899-904, 1993.

FURLANI, P.R.; SILVEIRA, L.C.P.; BOLONHOZI, D.; FAQUIN, V. Cultivo hidropônico de plantas. Campinas: IAC, 1999. 52p. (IAC. Boletim Técnico, 180). 
GARCÍA, V.N. Sistemas de solución perdida e recirculante: descripción, análisis y valoración. In : MARTÍNEZ, F.C.; ALVAREZ, J.S.D. (Ed). Cultivo sin suelo: curso superior de especialización. Almería: Servicio de Edición del Instituto de Estudios Almerinenses, 1993. cap.3. p.85-130.

GOMES JÚNIOR; MENEZES, J.B.; NUNES, G.H.S.; COSTA, F.B.; SOUZA, P.A. Qualidade pós-colheita de melão tipo cantaloupe, colhido em dois estádios de maturação. Horticultura Brasileira, v.19, n.3, p.356-360, nov. 2001

GÓMEZ-GUILLAMÓN, M.L.; FLORES, R.C.; GONZÁLEZ-FERNANDEZ, J.J. E1 melón in invernadero. In: VALLESPIR, A.N. Compendios de horticultura: melones. Barcelona: Ediciones de Horticultura. 1997. cap.8, p.67-77.

GRANGEIRO, L.C.; PEDROSA, J.F.; NETO, F.B.; NEGREIROS, M.Z. de. Qualidade de híbridos de melão amarelo em diferentes densidades de plantio. Horticultura Brasileira, v.17, n.2, p.110-113, julho 1999.

GRAVES, C.J. The nutrient film technique. In: JANICK, J. (Ed.). Horticultural reviews. Connecticut: AVI Publishung Company, 1983, v.5, cap.1, p.1-44.

GUIS, M.; BOTONDI, R.; BEN-AMOR, M.; AYUB, R.; BOUZAYEN, M.; PECH, J.C.; LATCHÉ, A. Ripening-associated biochimical traits of cantaloupe charentais melons expressing an antisense ACC oxidase transgene. Journal of the American Society for Horticultural Science, v.122, n.6, p.748-751, 1997.

GURGEL, F.L.; PEDROSA, J.F.; BEZERRA NETO, F.; NEGREIROS, M.Z. de. Qualidade de genótipos de melão amarelo avaliados em quatro ambientes. Horticultura Brasileira, v.18, p.663-664, julho 2000. Suplemento. 
GUSMÃO, S.A.L. de Interação genótipo $\mathrm{x}$ ambiente em híbridos de melão rendilhado (Cucumis melo L. var. reticulatus, Naud.). Jaboticabal, 2001. 143p. Tese (Doutorado) - Faculdade de Ciências Agrárias e Veterinárias, Universidade Estadual Paulista "Julio de Mesquita Filho".

HARTZ, T.K.; MIYO, G.; MULLEN, R.J.; CAHN, M.D.; VALENCIO, J.; BRITTON, K.L. Potassium requirements for maximum yield and fruit quality of processing tomato. Journal of the American Society for Horticultural Science, v.124, n.2, p.199-204, 1999.

HERNANDEZ, C.; BUSTOS, V.; ZAMUDIO, N. Fertirrigacion del melon bajo invernadero plastico. Revista Industrial y Agrícola de Tucumán, v.72, n.1/2, p.1$4,1995$.

HUBBARD, N.L.; HUBER, S.C.; PHARR, D.M. Sucrose phosphate synthase and acid invertase as determinats of sucrose concentration in developing muskmelon (Cucumis melo L.) fruits. Plant Physiology, v.91, n.4, p.1527-1534, Dec. 1989.

HUGHES, D.L.; BOSLAND, J.; YAMAGUCHI, M. Movements of photosynthates in muskmelon plants. Journal of the American Society for Horticultural Science, v.108, n.2, p.189-192, 1983.

HUTERWAL, G.O. Hidroponía: cultivo de plantas sin tierra. Buenos Aires: Editorial Hobby, 1960. p.33.

JONES JUNIOR, J.B. Hydroponics: its history and use plant nutrition studies. Journal of Plant Nutrition, v.5, n.8, p.1003-30, 1982.

JONES JUNIOR, J.B. A guide for the hydroponie and soilless culture grower. Portland: Timber Press, 1983. 124p. 
JUN, H.J.; KIM, D.H.; HWANG, J.G.; CHUNG, S.J. Effects of bed shape and foliar application of fertilizers on the growth and fruit quality of hydroponically grown melon (Cucumis melo L.). Journal of the Korean Society for Horticultural Science, v.40, n.1, p.1-3, 1999. / Resumo em CAB Abstracts on CD-ROM, 19982000/

JUNQUEIRA, A.H. Hortaliças: novos caminhos no ambiente protegido. In: FNP CONSUlTORIA \& COMÉRCIO, AGRIANUAL 1999: anuário estatístico da agricultura brasileira. São Paulo, 1999. p. 35 - 38.

KADER, A.A. Postharvest technology of horticulrural crops. Oakland: University of California, 1978. p.118-121: Quality factors: definition and evaluation for fresh horticultural crops.

KAGOHASHI, S.; KANO, H.; KAGEYAMA, M. Effects of controlling the nutrient uptake on the plant growth and the fruit qualities of muskmelons cultivated in the autumn and spring. Journal of the Japanese Society for Horticultural Science, v.50, n.3, p.306-316, 1981 .

KANO, H.; KAGOHASHI, S.; KAGEYAMA, M. Relationship between organ growth and nitrogen accumulation in muskmelon. Journal of the Japanese Society for Horticultural Science, v.50, n.3, p. 317-325, 1981.

KAVANEL, D.E. Growth, development, and yield potential of short-internode muskmelon. Journal of the American Society for Horticultural Science, v113, n.4, p.595-599, 1988.

KHOSLA, S.; PAPADOPOULOS, A.P. Influence of K:N ratio and $\mathrm{EC}$ on tomato plant raising. Acta Horticulturae, n.548, p.149-156, 2001. / International Symposium on Growing Media \& Hydroponics, Macedonia, 1999 / 
LESTER, G. Comparisons of "Honey Dew" and netted muskmelon fruit tissues in relation to storage life. HortScience, v.23, n.1, p.180-182, Feb. 1988.

LESTER, G. Lipoxygenase activity of hypodermal-and middle-mesocarp tissues from netted muskmelon fruit during maturation and storage. Journal of the American Society for Horticultural Science, v.115, n.4, p.612-615, 1990

LESTER, G. Physicochemical characterization of hybrid Honey Dew muskmelon fruit (Cucumis melo L. var. inodorus Naud.) following maturation, abscission, and postharvest storage. Journal of the American Society for Horticultural Science, v.123, n.1, p.126-129, 1998.

LESTER, G.; SHELLIE, K.C. Postharvest sensory and physicochemical attributes of Honey Dew melon fruits. HortScience, v.27, n.9, p.356-360, Sept. 1992.

LESTER, G.; STEIN, E. Plasma membrane physicochemical changes during maturation and postharvest storage of muskmelon fruit. Journal of the American Society for Horticultural Science, v.118, n.2, p.223-227, 1993.

LOPES, J.F. Melhoramento genético (chuchu, melancia, melão e pepino). Informe Agropecuário, v.8, n.85, p.61-65, jan. 1982.

MALAVOLTA, E.; CROCOMO, O.J. O potássio e a planta. In: SIMPÓSIO SOBRE POTÁSSIO NA AGRICULTURA BRASILEIRA, Londrina, 1982. Anais. Londrina: Fundação IAPAR, 1982. p.95-162.

MARINO, L.K.; MENDES, M.; PRADO, E. Fraca presença das frutas brasileiras no exterior. In: FNP CONSULTORIA \& COMÉRCIO, AGRIANUAL 2001: anuário estatístico da agricultura brasileira. São Paulo, 2001. p.22-25. 
MARSCHNER, H. Mineral nutrition of higher plants. 2. ed. London: Academic Press, 1995. cap.15, p.537-595: The soil-root interface (rhizosphere) in relation to mineral nutrition.

MARTINEZ, H.E.P. Formulação de soluções nutritivas para cultivos hidropônicos comerciais. Jaboticabal: FUNEP, 1997. 31p.

MARTINEZ, H.E.P.; BARBOSA, J.G. O uso de substratos em cultivos hidropônicos. Viçosa: UFV, 1999. 41 p.

MARTINEZ, H.E.P.; SILVA FILHO, J.B. da Introdução ao cultivo hidropônico de plantas. Viçosa: s. ed., 1997. 52p.

MARTINS, S.R.; PEIL, R.M.; SCHWENGBER, J.E.; ASSIS, F.N.; MENDEZ, M.E.G. Produção de melão em função de diferentes sistemas de condução de plantas em ambiente protegido. Horticultura Brasileira, v.16, n.1, p.24-30, maio 1998.

MARUYAMA, W.I. Condução de melão rendilhado sob cultivo protegido. Jaboticabal, 1999. 42p. Dissertação (M.S.) - Faculdade de Ciências Agrárias e Veterinárias, Universidade Estadual Paulista "Julio de Mesquita Filho".

MELO, A.M.T. de; NAGAI, H.; TRANI, P.E. Melão Cucumis melo L. In: FAHL, J.I.; CAMARGO, M.B.P. de; PIZZINATO, M.A.; BETTI, J.A; MELO, A.M.T.; DEMARIA, I.C.; FURLANI, A.M.C. Instruções agrícolas para as principais culturas econômicas. 6.ed. Campinas: Instituto Agronômico, 1998. p.219 -221. (Boletim, 200).

MENDLINGER, S. Effect of increasing plant density and quality of muskmelon. Scientia Horticulturae, v.57, p.41-49, 1994. 
MENEZES, J.B. Qualidade pós-colheita de melão tipo Galia durante a maturação e o armazenamento. Lavras, 1996. 157p. Tese (Doutorado) - Universidade Federal de Lavras.

MENEZES, J.B.; CHITARRA, A.B.; CHITARRA, M.I.F.; BICALHO, U.O. Caracterização do melão tipo Galia durante a maturação. Horticultura Brasileira, v.16, n.2, p. 123-127, nov. 1998a.

MENEZES, J.B.; CHITARRA, A.B.; CHITARRA, M.I.F.; BICALHO, U.O. Qualidade do melão tipo Galia durante o armazenamento refrigerado. Horticultura Brasileira, v.16, n.2, p. 159-164, nov. 1998 b.

MICCOLIS, V.; SALTVEIT JUNIOR, M.E. Morphological and physiological changes during fruit growth and maturation of seven melon cultivars. Journal of the American Society for Horticultural Science, v.116, n.6, p.1025-1029, 1991.

MONTEIRO, A.A.; MEXIA, J.T. Influência da poda e do número de frutos por planta na qualidade dos frutos e produtividade de melão. Horticultura Brasileira, v.6, n.1, p.9-12, maio 1988.

MORTLEY, D.G.; BONSI, C.K.; HILL, J.H.; HILL, W.A. Nutrient management of sweetpootato grown in nutrient film technique. Acta Horticulturae, n.548, p.567573, 2001. / International Symposium on Growing Media \& Hydroponics, Macedonia, 1999 /

MORTLEY, D.G.; BONSI, C.K.; HILL, W. A.; LORETAN, P. A.; MORRIS, C.E. Irradiance and nitrogen to potassium ratio influences sweetpotato yield in Nutrient Film Technique. Crop Science, v.33, p.782-784, 1993. 
PAPADOPOULOS, A.P. Growing greenhouse seedless cucumbers in soil in soilless media. Ottawa: Agriculture and Agri-food Canada, 1994. 126p. (Publication, 1902/E).

PARDOSSI, A.; MALORGIO, F.; TOGNONI, F. Control of mineral nutrition in melon plants grown with NFT. Acta Horticulturae, n.396, p.173-180, 1995. / Apresentado ao 24. International Horticultural Congress: Hydroponics and Transplant Production, Kyoto, 1994/

PARDOSSI, A.; LANDI, S.; MALORGIO, F.; CECCATELLI, M.; TOGNONI, F. Studies on melon grown with NFT. Acta Horticulturae, n.361, p.186-193, 1994.

PARDOSSI, A.; GIACOMET, P.; MALORGIO, F.; ALBINI, F.M.; MURELLI, C.; SERRA, G.; VERNIERI, P.; TOGNONI, F. The influence of growing season on fruit yield and quality of greenhouse melon (Cucumis melo L.) grown in Nutrient Film Technique in a Mediterranean climate. Journal of the Horticultural Science \& Biotechnology, v.75, n.4, p.488-493, 2000.

PEREIRA, C.; MARCHI, G. Cultivo comercial em estufa. Guaíba: Agropecuária, 2000. p.91 -116: Net melon (Cucumis melo var reticulatus).

PINTO, J.M.; BOTREL, T.A.; FIETZ, C.R.; FEITOSA FILHO, J.C. Estudo da dose de potássio em cultura de melão (Cucumis melo L.) via fertirrigação. Engenharia Rural, v.7, n.único, p.62-67, 1996 b.

PINTO, J.M.; SOARES, J.M.; CHOUDHURY, N.E.; PEREIRA, J.R. Aplicação de potássio via água de irrigação na cultura do melão. Pesquisa Agropecuária Brasileira, v.28, n.3, p.323-327, mar. 1993. 
PINTO, J.M.; SOARES, J.M.; COSTA, N.D.; BRITO, L.T.L.; PEREIRA, J.R. Aplicação de $\mathrm{N}$ e K via água de irrigação em melão. Horticultura Brasileira, v.13, n.2, p.192-195, nov. 1995.

PINTO, J.M.; SOARES, J.M.; PEREIRA, J.R.; COSTA, N.D.; BRITO, L.T. de L.; FARIA, C.M.B. de; MACIEL, J.J. Sistema de cultivo de melão com aplicação de fertilizantes via água de irrigação. Brasília: Embrapa, 1996a, 24p. (Circular Técnica, 36).

PONTES, A.L. Cultivo hidropônico do tomateiro (Lycopercicon esculentum Mill.) utilizando dois sistemas de aplicação da solução nutritiva, com diferentes relações K:N. Piracicaba, 2001. 83p. Dissertação (Mestrado) - Escola Superior de Agricultura "Luiz de Queiroz", Universidade de São Paulo.

PRABHAKAR, B.S.; SRINIVAS, K.; SHUKLA, V. Yield and quality of muskmelon (cv. Hara Madhu) in relation to spacing and fertilization. Progressive Horticulture, v.17, n.1, p.51-55, 1985 .

RAIJ, B. van; CATARELLA, H.; QUAGGIO, J.A.; FURLANI, A.M.C. Recomendações de adubação e calagem para o Estado de São Paulo. 2.ed. Campinas: Fundação IAC, 1997. 285p. (Boletim Técnico, 100).

RESH, H. M. Cultivo hidroponico: nuevas tecnicas de produccion, una guia completa de los metodos actuales de cultivo sin solo, para tecnicos y agricultores profisionales, asi como para los aficionados especializados. 3. ed. Madrid: Mundi-Prensa, 1992. 369 p.

RINCÓN SANCHEZ, L. Fertilización del melón en riego por goteo. In: In: VALLESPIR, A.N. Compendios de horticultura: melones. Barcelona: Ediciones de Horticultura. 1997. cap.10, p.85-93. 
RINCÓN SANCHEZ, L.; SÁEZ SIRONI, J.; PÉREZ CRESPO, J.A.; MADRID, R. Growth and nutrient absorption by muskmelon crop under greenhouse conditions. Acta Horticulturae, n.458, p.153-159, 1998. / International Symposium on Water Quality and Quantity in Greenhouse Horticulture, Tenerife, 1996 /

SAS INSTITUTE. Statistical analysis system, release 6.08, (software). Cary, 1992. $620 \mathrm{p}$.

SCHWARTZ, G.; KUCHENBUCH, R. Growth analysis of tomato in a closed recirculating system in relation to the $\mathrm{EC}$ value of the nutrient solution. Acta Horticulturae, n.450, p.169-176, 1997. / International Symposium on Growing Media and Plant Nutrition in Horticulture, Freising, 1996 /

SCHWARZ, D.; KLARING, H.P.; INGRAM, K.T.; HUNG, Y.C. Model-based control of nutrient solution concentration influences tomato growth and fruit quality. Journal of the American Society for Horticultural Science, v.126, n.6, p.778-784, 2001.

SCOTT, G.W.; MacGILLIVRAY, J.H. Variation in solids of the juice from different regions in melon fruits. Hilgardia, v.13, n.2, p.69-79, Feb. 1940.

SHILLIE, K.C.; SALTVEIT JUNIOR, M.E. The lack of a respiraty rise in muskmelon fruit repening on the plant challenges the difinition of climacteric behaviour. Journal of Experimental Botany, v.44, n.265, p.1403-1406, Aug. 1993.

SHIPPERS, P.A. Compositions changes in the nutrition solution during the growth of plants in recirculating nutrient culture. Acta Horticulturae, n.98, p.103-118, 1980. / Apresentado ao 1. Symposium On Research On Recirculating Water Culture, Littlehampton, 1979. 
SOARES, A.J. Efeitos de três lâminas de irrigação e de quatro doses de potássio na fertirrigação no meloeiro em ambiente protegido. Piracicaba, 2001. 67p. Dissertação (Mestrado) - Escola Superior de Agricultura "Luiz de Queiroz", Universidade de São Paulo.

SOBRINO ILLESCAS, E; SOBRINO VESPERINAS, E. Tratado de horticultura: 1 hortalizas de flor y de fruto. Barcelona:AEDOS, 1989. p.155-182: Melón.

SOUSA, V.F. de. Níveis de irrigação e doses de potássio aplicados via fertirrigação por gotejamento no maracujazeiro amarelo (Passiflora edulis Sims. f. flavicarpa Deg.). Piracicaba, 2000. 174p. Tese (Doutorado) - Escola Superior de Agricultura "Luiz de Queiroz", Universidade de São Paulo.

SOUZA, M.C.; MENEZES, J.B; ALVES, R.E. Tecnologia pós-colheita e produção de melão no estado do Rio Grande do Norte. Horticultura Brasileira, v.12, n.2, p.188-190, 1994.

STAFF, H. Hidroponia. 2.ed. Cuiabá: SEBRAE/MT, 1998. 101p. (Coleção Agroindústria, 11).

STOUGHTON, R.H. Soilless cultivation and its application to commercial horticultural crop production. Rome: FAO, 1969. 61p.

TEIXEIRA, N.T. Hidroponia: uma alternativa para pequenas áreas. Guaíba: Editora Agropecuária, 1996. 86p.

TORRES, J.M. Los tipos de melón comerciales. In: VALLESPIR, A.N. Compendios de horticultura: melones. Barcelona: Ediciones de Horticultura, 1997. cap.1, p.1320. 
TREMBLAY, N.; SENECAL, M. Nitrogen and potassium in nutrient solution influence seedling growth of four vegetable species. HortScience, v.23, n.6, p.10181020, Dec. 1988.

TYLER, K.B.; LORENZ, O.A. Nutrient absorption and growth of four muskmelon varieties. Proceedings of the American Society for Horticultural Science, v.84, p.364-371, 1964.

WEBSTER, B.D. Anatomical and histochemicalmodifications associated with abscission of Cucumis fruits. Journal of the American Society for Horticultural Science, v.100, n.2, p.180-184, 1975.

WIDEN, C.M.M. van. Soilless culture technique and its relation to the greenhouse climate. Acta Horticulturae, n.229, p.125-132, 1988.

WILCOX, G.E. The future of hydroponics as a research and plant production method. Journal of Plant Nutrition, v.5, n.8, p.1031-1038, 1982.

WINSOR, G.W. Progress in nutrient film culture. Span, v.23, n.1, p.7-9, 1980.

YAMAGUCHI, M.; HUGHES, D.L.; YABUMOTO, K.; JENNINGS, W.G. Quality of cantaloupe muskmelons: variability and attributes. Scientia Horticulturae, v.6, n.59-70, 1977.

ZAPATA NICOLAS, M.; CABRERA FERNANDEZ, P.; BAÑON ARIAS, S.; ROTH MARTINEZ, P. El melon. Madrid: Ediciones Mundi-Prensa, 1989. 174p. 